\title{
BIANCA CESTARI ZYCHAR
}

\section{INTERAÇÃO LEUCÓCITO-ENDOTÉLIO INDUZIDA PELO VENENO DE BOTHROPS JARARACA: PAPEL DE PROTEASES, MEDIAÇÃO FARMACOLÓGICA E SORONEUTRALIZAÇÃO}

Dissertação apresentada ao Programa de Pós-graduação Interunidades em Biotecnologia/USP/Instituto Butantan/ IPT, para obtenção do título de Mestre em Biotecnologia. 


\section{INTERAÇÃO LEUCÓCITO-ENDOTÉLIO INDUZIDA PELO VENENO DE BOTHROPS JARARACA: PAPEL DE PROTEASES, MEDIAÇÃ̃ FARMACOLÓGICA E SORONEUTRALIZAÇÃO}

\section{BIANCA CESTARI ZYCHAR}

Dissertação apresentada ao Programa de Pós-graduação Interunidades em Biotecnologia/USP/Instituto Butantan/ IPT, para obtenção do título de Mestre em Biotecnologia.

São Paulo

2007 


\section{INTERAÇÃO LEUCÓCITO-ENDOTÉLIO INDUZIDA PELO VENENO DE BOTHROPS JARARACA: PAPEL DE PROTEASES, MEDIAÇÃO FARMACOLÓGICA E SORONEUTRALIZAÇÃO}

\section{BIANCA CESTARI ZYCHAR}

Dissertação apresentada ao Programa

de Pós-graduação Interunidades em Biotecnologia/USP/Instituto Butantan/ IPT, para obtenção do título de Mestre em Biotecnologia.

Área de concentração:

Biotecnologia

Orientador:

Dr. Luis Roberto de Camargo Gonçalves

São Paulo

2007 


\section{CERTIFICADO}

Certificamos que o Protocolo para uso de animais em experimentação $n^{\circ}$ 199/05, sobre o projeto intitulado "Proteases do veneno de Bothrops jararaca na interação leucócito-endotélio", sob a responsabilidade de Luis Roberto de Camargo Gonçalves está de acordo com os Princípios Éticos na Experimentação Animal adotado pelo Colégio Brasileiro (COBEA) e foi aprovado pela COMISSÃO DE ÉTICA NO USO DE ANIMAIS DO INSTITUTO BUTANTAN (CEUAIB) em reunião de 08/03/2005.

São Paulo, 09 de março de 2005.

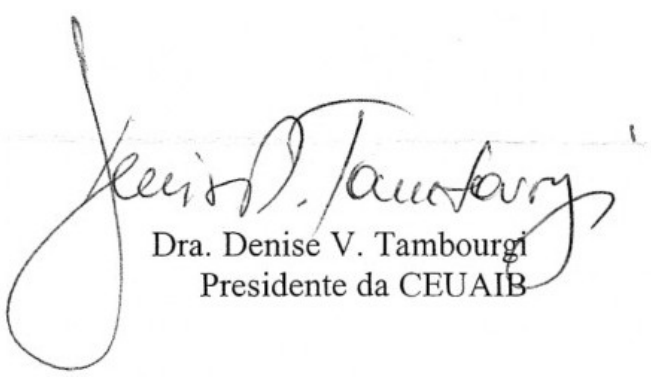


Dedico este trabalho

Aos meus pais Olivia e Vicente

Pelo amor, dedicação, carinho,

por tudo que me ensinaram e pelo apoio

constante para a minha formação.

Muito obrigado!!!

Ao meu irmão Marcio,

Pela amizade, cumplicidade e companheirismo!

"Amo muito vocês" 
Ao Luís,

Pela amizade, orientação, paciência

e sua dedicação em me ensinar sempre.

"O sábio não é o homem que fornece as respostas verdadeiras;

é o que formula as perguntas verdadeiras".

Lévi-Strauss 


\section{Aos amigos}

Ao laboratório de Fisiopatologia do Instituto Butantan pelo inestimável auxílio para realização deste trabalho e convivência.

A Rosana pela grande amizade e companheirismo, apoio, pela ajuda neste trabalho, e claro por todas nossas 6aladas, está fazendo muita falta no laboratório. Você é muito especial!

Ao Flávio, por estar sempre presente mesmo estando longe, por todas conversas e almoços, mesmo sendo muuuuito chato, fará muita falta;

A Cris, pela amizade, pelas "constantes" discussões e conselhos, minha segunda mãe;

A Carolina, com sua super ternura réptil e companheirismo, e claro pelas baladinhas;

A Fernanda e ao Júnior, pela amizade, carinho, pelas boas risadas e ajuda nos experimentos;

Ao Thi, Alexandre, Márcio, Tati e Priscila, pela amizade, pelos nossos almoços de todo dia e risadas. Sejam muito bem vindos ao laboratório;

A Maru, Camis e Van, pelo carinho e disposição sempre para tudo, que as tornam muito especiais;

A minha família pelo apoio constante e por confiarem muito em mim;

A Luaninha pela amizade desde os tempos da faculdade;

"sem vocês eu nada seria....muito obrigado....." 
Aos pesquisadores e alunos de pós-graduação do laboratório de Fisiopatologia, pela dedicação e auxílio, convívio e amizade;

A Dra. Ida S. Sano-Martins por permitir a realização deste trabalho e pelo apoio;

Aos funcionários Iracema, Nicolau, Neusinha, Neucely, Juscelino, Terezinha, D. Alice e Ângela indispensáveis para a realização deste trabalho;

A secretaria do Programa de Pós-graduação Interunidades em Biotecnologia, pela ajuda, atenção, carinho e paciência com que sempre me rece6eram;

À Coordenação de Aperfeiçoamento de Pessoal de Nível Superior (CAPES) e a Fundação de Amparo à Pesquisa do Estado de São Paulo (FAPESP) pelo suporte financeiro.

Enfim,

A todos aqueles que colaboram de alguma forma para a realização deste trabalho.

Muito obrigada!!!!!! 
"A mente que se abre a uma nova idéia jamais

voltará ao seu tamanho original"

Albert Einstein

Este trabalho foi realizado no Laboratório de Fisiopatologia do Instituto Butantan 
Zychar BC. Interação leucócito-endotélio induzida pelo veneno de Bothrops jararaca: papel de proteases, mediação farmacológica e soroneutralização [Dissertação] - São Paulo: Instituto de Ciências Biomédicas da Universidade de São Paulo, 2007.

Toxinas classificadas como serinoproteases, metaloproteases e fosfolipases $\mathrm{A}_{2}$, isoladas de venenos botrópicos, podem induzir reações inflamatórias que contribuem na gravidade dos sintomas locais observados nestes envenenamentos. Entretanto, a contribuição efetiva de cada uma destas toxinas no efeito inflamatório induzido pelo veneno não é bem compreendida. Neste estudo, o veneno de Bothrops jararaca (VBj) foi tratado com Fluoreto de fenil-metil-sulfonila (PMSF), 1,10- fenantrolina (OF) ou Brometo de $p$-bromafenacila ( $p$ BPB) para inibição destas enzimas. Observou-se parâmetros de leucócitos em rolling, aderidos e migrados na interação leucócito-endotélio, após a injeção de $1 \mu \mathrm{g}$ dos veneno tratados no subcutâneo da bolsa escrotal de camundongos. Os resultados foram comparados aos obtidos com o veneno bruto, sem tratamento. Os animais injetados com VBj bruto apresentaram um aumento marcante de adesão celular em todos os tempos estudados, sendo o pico dessa interação entre a $2^{\mathrm{a}}$ e $4^{\mathrm{a}}$ hora após a injeção. Os grupos injetados com VBj também apresentaram o maior número de células migradas na $4^{\mathrm{a}} \mathrm{h}$, permanecendo esse número alto na $24^{\mathrm{a}}$ hora e diminuindo significativamente na $48^{\mathrm{a}} \mathrm{h}$ após a injeção do VBj. Baseando-se nesta cinética, todos os outros estudos foram verificados na $2^{\mathrm{a}}$ e $24^{\mathrm{a}}$ hora. Os resultados mostraram que o tratamento do VBj com OF resultou diferenças significantes nas alterações da interação leucócito-endotélio. Nos venenos tratados para inibição de serinoproteases e FLA 2 verificouse que o tratamento não resultou em diferenças nos parâmetros de interação leucócitoendotélio, quando comparados ao grupo injetado com o veneno bruto, nos dois tempos estudados. Tratamentos farmacológicos indicam que os eicosanóides originados da via da ciclooxigenase, TNF- $\alpha$ e NO participam da mediação da interação leucócito endotélio induzidos pelo VBj. Mas aparentemente não os eicosanóides originados pela via das lipoxigenase, histamina ou serotonina,. $\mathrm{O}$ efeito do soro antibotrópico (SAB) na interação leucócito-endotélio induzido por VBj também foi avaliado. O SAB induziu, per se, uma interação leucócito-endotélio semelhante ao observado em animais injetados com VBj, efeito este aparentemente devido ao fenol utilizado como conservante no antiveneno. Utilizando-se um soro antibotrópico sem fenol, estas reações não foram observadas e verificou-se que o soro sem fenol evita as alterações na interação leucócito-endotélio induzidas pelo VBj. Em conclusão, conjuntamente nossos dados indicam que: 1) as metaloproteases tem maior 
importância, e que as fosfolipases e serinoproteases tem um papel secundário nas alterações na interação leucócito-endotélio induzida pelo $\mathrm{VBj}$; 2) que os eicosanóides são os principais mediadores nestes parâmetros inflamatórios e 3) que o SAB possui anticorpos contra as toxinas do veneno que induzem alterações na interação, mas o fenol presente no soro é responsável pelas reações pró-inflamatórios indesejadas. Finalmente, os resultados sugerem que a associação de antiinflamatórios à soroterapia para o tratamento das reações inflamatórias locais induzidas pelo $\mathrm{VBj}$ deve ser considerada e estudada mais aprofundadamente.

Palavras-chave: Bothrops jararaca, inflamação, microcirculação, cremaster, interação leucócito-endotélio, proteases, mediação farmacológica, soro antibotrópico. 
Zychar BC. Leukocyte-endothelium interaction induced by Bothrops jararaca venom: role of proteases, pharmacological mediation and serum neutralization [Dissertação]- São Paulo: Instituto de Ciências Biomédicas da Universidade de São Paulo, 2007.

Toxins classified as serineproteases, metalloproteases or phospholipases $A_{2}$, isolated from venoms of Bothrops snakes can induce inflammatory reactions that contribute to the severity of local symptoms observed in envenomation. Nevertheless, the real contribution of each one of these classes of toxins to the inflammatory effect of whole venom is poorly understood. In this study, Bothrops jararaca venom (BjV) was treated with phenyl-methyl-sulfonyl-fluoride (PMSF), 1,10-phenantroline ( $\sigma$ Phe) or p-bromophenacyl bromide ( $p$ BPB), to inhibit those classes of enzymes. Inflammatory parameters of leukocyte-endothelial interaction (LEI), namely leukocytes rolling, adhesion or migration, observed after injecting of $1 \mu \mathrm{g}$ of treated venoms into the subcutaneous tissue of the scrotal bag of mice, were evaluated and compared to those observed after the injection of non-treated venom. Animals injected with $\mathrm{BjV}$ presented an a marked expressive increase in cellular adhesion in all periods of time studied, but peaking between 2 and $4 \mathrm{~h}$ after BjV injection. The venom-injected groups also presented the highest number of migrated cells hour 4 , wich remained up to hour 24 , and decreasing significantly $48 \mathrm{~h}$ after the $\mathrm{BjV}$ injection. Based on this kinetics, all other studied were performed evaluating LEI parameters on 2nd and 24th hour after venom injection. Results showed that $\sigma$ Phe -treated venom presented significant differences in LEI. LEI parameters induced by $p$ BPB- and PMSF-treated venom were similar to those observed with non-treated venom. Pharmacological treatments indicate that eicosanoids from the cyclooxygenase pathway, TNF- $\alpha$ and NO participate on the mediation of the alterations of leukocyteendothelium interaction induced by venom. Eicosanoids from the lipoxygenase pathway, histamine and serotonin apparently do not mediate these alterations. The effect of the Bothrops antivenom in blocking the disturbances of leukocyte-endothelial interaction induced by $\mathrm{BjV}$ was also evaluated. Surprisingly, the antivenom per se induced alterations in LEI similar to those induced by the venom. Conversely, a phenol-free antivenom did not induce LEI alterations and avoid those induced by the $\mathrm{BjV}$. In conclusion, our findings indicated that: 1) the major importance of metalloproteases, and a secondary role for phospholipases and serineproteases in alterations of leukocyte-endothelial interactions induced by Bothrops jararaca venom; 2) eicosanoids are the main mediators of these alterations; 3) the Bothrops 
antivenom has antibodies against toxins that induce LEI alteration, but the phenol used in antivenom as a preservative can cause some undesired pro-inflammatory reactions. Finally, present results indicate that the use of anti-inflammatory drugs associated with serum therapy for the treatment of local inflammatory reactions induced by Bothrops snake venoms should be considered and further studied.

Key words: Bothrops jararaca, inflammation, microcirculation, cremaster, leukocyteendothelium interaction, proteases, pharmacological mediation, Bothrops antivenom. 


\section{LISTA DE ILUSTRAÇÕES}

Figura 1 Serpente Bothrops jararaca .......................................................... 24

Figura 2 Mediadores químicos derivados de fosfolipídeos................................ 30

Figura 3 Cascata de múltiplas interações de moléculas de adesão.......................

Figura 4 Cinética da interação leucócito-endotélio em vênulas pós-capilares na microcirculação do músculo cremaster de camundongos induzida pelo veneno de Bothrops jararaca $(\mathrm{VBj})$

Figura 5 Interação leucócito-endotélio em vênulas pós-capilares na microcirculação do músculo cremaster de camundongos após $2 \mathrm{~h}$ ou 24h da injeção de salina ou VBj. Os animais foram injetados com

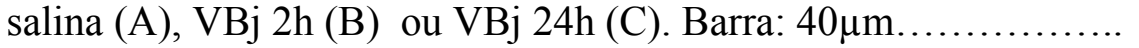

Figura 6 Interação leucócito-endotélio induzidos pelo veneno de Bothrops jararaca $(\mathrm{VBj})$ tratados quimicamente em vênulas pós-capilares na microcirculação do músculo cremaster de camundongos $-2 \mathrm{hs}$.

Figura 7 Interação leucócito-endotélio induzidos pelo veneno de Bothrops jararaca $(\mathrm{VBj})$ tratados quimicamente em vênulas pós-capilares na microcirculação do músculo cremaster de camundongos -24hs.

Figura 8 Efeito do pré-tratamento com prometazina na interação leucócitoendotélio em vênulas pós-capilares na microcirculação do músculo cremaster de camundongos induzido pelo veneno de Bothrops jararaca $(\mathrm{VBj})$.

Figura 9 Efeito do pré-tratamento com metissergida na interação leucócitoendotélio em vênulas pós-capilares na microcirculação do músculo cremaster de camundongos induzido pelo veneno de Bothrops jararaca $(\mathrm{VBj})$.

Figura 10 Efeito do pré-tratamento com dexametasona na interação leucócitoendotélio em vênulas pós-capilares na microcirculação do músculo cremaster de camundongos induzido pelo veneno de Bothrops jararaca $(\mathrm{VBj})$.

Figura 11 Efeito do pós-tratamento com dexametasona na interação leucócitoendotélio em vênulas pós-capilares na microcirculação do músculo cremaster de camundongos induzido por $\mathrm{VBj}$. 
Figura 12 Efeito do pré-tratamento com indometacina interação leucócitoendotélio em vênulas pós-capilares na microcirculação do músculo cremaster de camundongos induzido pelo veneno de Bothrops jararaca $(\mathrm{VBj})$

Figura 13 Efeito do pré-tratamento com celecoxib interação leucócitoendotélio em vênulas pós-capilares na microcirculação do músculo cremaster de camundongos induzido pelo veneno de Bothrops jararaca $(\mathrm{VBj})$.

Figura 14 Efeito do pré-tratamento com Ácido nordiidroguaiarético (NDGA) na interação leucócito-endotélio em vênulas pós-capilares na microcirculação do músculo cremaster de camundongos induzido pelo veneno de Bothrops jararaca (VBj)

Figura 15 Efeito do pré-tratamento com pentoxifilina na interação leucócitoendotélio em vênulas pós-capilares na microcirculação do músculo cremaster de camundongos induzido pelo veneno de Bothrops jararaca $(\mathrm{VBj})$.

Figura 16 Efeito do pré-tratamento com L-N ${ }^{G}$-nitro arginina metil ester (Lname) na interação leucócito-endotélio em vênulas pós-capilares na microcirculação do músculo cremaster de camundongos induzido pelo veneno de Bothrops jararaca (VBj)

Figura 17 Efeito do pré-tratamento com Aminoguanidina (Amino) na interação leucócito-endotélio em vênulas pós-capilares na microcirculação do músculo cremaster de camundongos induzido pelo veneno de Bothrops jararaca (VBj).

Figura 18 Efeito do pré-tratamento com soro antibotrópico (SAB) na interação leucócito-endotélio induzido pelo veneno de Bothrops jararaca (VBj) em vênulas pós-capilares na microcirculação do músculo cremaster de camundongos

Figura 19 Interação leucócito-endotélio em vênulas pós-capilares na microcirculação do músculo cremaster de camundongos induzida pelo soro antibotrópico, fenol ou soro antibotrópico sem fenol.

Figura 20 Efeito do pré-tratamento de prometazina na interação leucócitoendotélio em vênulas pós-capilares na microcirculação do músculo cremaster de camundongos induzida pelo soro antibotrópico ou fenol.

Figura 21 Efeito do pré-tratamento com soro antibotrópico sem fenol na interação leucócito-endotélio em vênulas pós-capilares na microcirculação do músculo cremaster de camundongos induzido pelo veneno de Bothrops jararaca (VBj) 
Figura 22 Efeito do pós-tratamento com soro antibotrópico sem fenol na interação leucócito-endotélio em vênulas pós-capilares na microcirculação do músculo cremaster de camundongos induzido pelo veneno de Bothrops jararaca (VBj)......

Figura 23 Efeito da associação de dexametasona com soro antibotrópico na interação leucócito-endotélio em vênulas pós-capilares na microcirculação do músculo cremaster de camundongos induzido pelo veneno de Bothrops jararaca (VBj). 


\section{LISTA DE ABREVIATURAS}

\begin{tabular}{|c|c|}
\hline ADAMS & A disintegrin and metalloproteinase \\
\hline AINEs & Fármacos antiinflamatórios não esteróidais \\
\hline BAPNA & N-benzoyl-L-arginine-p-nitroanilide \\
\hline $\mathrm{CaCl}_{2}$ & Cloreto de cálcio \\
\hline COX-1 & Cliclooxigenase- 1 \\
\hline COX-2 & Ciclooxigenase-2 \\
\hline Dx & Dexametasona \\
\hline ESL-1 & E-selectin ligand-1 \\
\hline $\mathbf{F}\left(\mathbf{a b} \mathbf{b}^{\prime}\right)_{2}$ & Fragmento da molécula do anticorpo de IgG \\
\hline Fab & Fragmento da molécula do anticorpo de IgG \\
\hline $\mathbf{F L A}_{2}$ & Fosfolipase $\mathrm{A}_{2}$ \\
\hline GlyCAM & Glycosylation dependent cell adhesion molecule-1 \\
\hline $\mathrm{HCl}$ & Ácido clorídrico \\
\hline ICAM-1 & intercellular adhesion molecule-1 \\
\hline ICAM-2 & intercellular adhesion molecule-2 \\
\hline IgG & Imunoglobulina $\mathrm{G}$ \\
\hline IL-1 & Interleucina -1 \\
\hline IL-6 & Interleucina -6 \\
\hline INF- $\gamma$ & Interferon $-\gamma$ \\
\hline MadCAM & $\begin{array}{l}\text { Mucosal addressin cellular adhesion molecule-1 } \\
\text { Cloreto de sódio }\end{array}$ \\
\hline \multicolumn{2}{|r|}{ 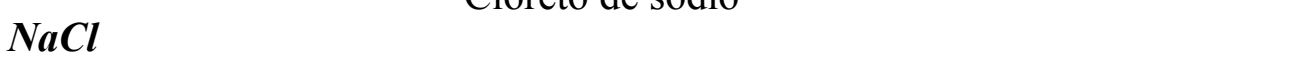 } \\
\hline & Ácido nordiidroguaiarético \\
\hline \multicolumn{2}{|l|}{$N D G A$} \\
\hline & Óxido nítrico \\
\hline \multicolumn{2}{|r|}{ 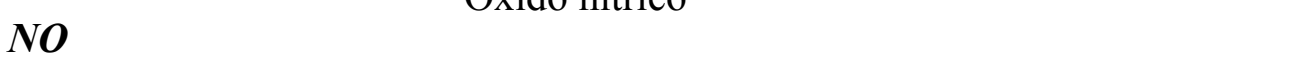 } \\
\hline & Óxido nítrico sintase \\
\hline \multicolumn{2}{|l|}{ NOS } \\
\hline OF & 1,10-fenantrolina \\
\hline p-BPB & Brometo de $p$-bromafenacila \\
\hline PECAM-1 & platelet endothelial cell adhesion molecule-1 \\
\hline $\mathbf{P G E}_{2}$ & Prostaglandina $\mathrm{E}_{2}$ \\
\hline $\mathbf{P G I}_{2}$ & Prostaciclina \\
\hline PMSF & Fluoreto de fenil-metil-sulfonila \\
\hline PSGL-1 & P-selectina glycoprotein ligand-1 \\
\hline PTX & Pentoxifelina \\
\hline SAB & Soroantibotrópico \\
\hline TACE & TNF-converting enzyme \\
\hline TNF- $\alpha$ & Fator de necrose tumoral - $\alpha$ \\
\hline $\mathbf{V B j}$ & Veneno de Bothrops jararaca \\
\hline VCAM-1 & Vascular cell adhesion molecule-1 \\
\hline
\end{tabular}




\section{SUMÁRIO}

$1 \quad$ INTRODUÇ̃̃O

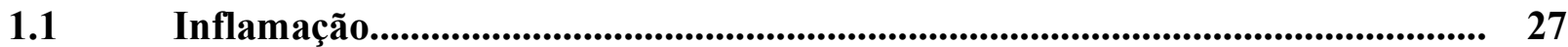

1.1.1 Mediadores inflamatórios................................................................................... 28

1.2 Interação leucócito-endotélio........................................................................ 32

$1.2 .1 \quad$ Rolling.................................................................................................................... 33

1.2.2 Firme adesão......................................................................................... 34

1.2.3 Migração celular..................................................................................................... 35

1.3 Resolução da inflamação....................................................................................... 36

$1.4 \quad$ Fármacos antiinflamatórios....................................................................... 37

$1.5 \quad$ Soroterapia.................................................................................................................. 38

2 OBJETIVO

3 MATERIAL E MÉTODOS........................................................................ 42

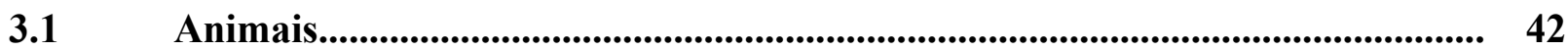




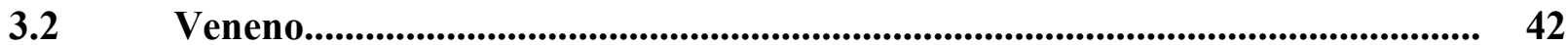

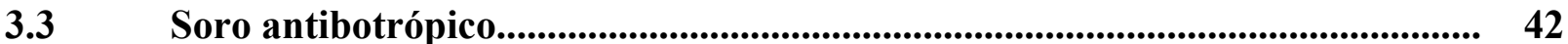

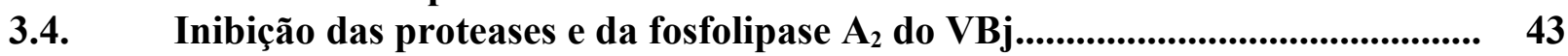

3.4.1 Inibição das proteases......................................................................................... 43

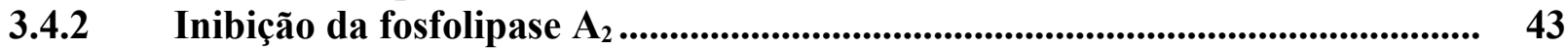

3.5 Avaliação do efeito inibitório das atividades das toxinas do VBj..................... 44

3.5.1 Atividade de metaloproteases.............................................................................. 44

3.5.2 Atividade de serinoproteinases............................................................................. 44

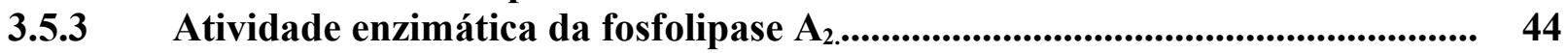

3.6 Avaliação da interação leucócito-endotélio......................................................... 45

3.7 Tratamentos farmacológicos e soroterapia........................................................... 46

$3.8 \quad$ Análise Estatística................................................................................................... 48

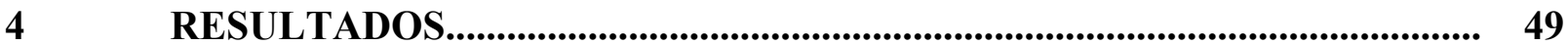

4.1 Cinética dos eventos de interação leucócito-endotélio induzidos pelo $\mathrm{VBj}$...... 49

4.2 Atividade inibitória de proteases e da fosfolipase $A_{2}$ do VBj........................... 49

4.3 Interações leucócito-endotélio induzidas por VBj com proteases ou FLA

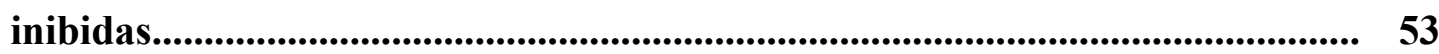

4.4 Mediação farmacológica da interação leucócito-endotélio induzida por VBj. 53

4.4.1 Participação da histamina na interação leucócito-endotélio induzida por VBj............................................................................................................... 53

4.4.2 Participação da serotonina na interação leucócito-endotélio induzida por VBj......................................................................................................

4.4.3 Participação dos metabólitos da degradação do ácido araquidônico na interação leucócito-endotélio induzida por VBj.............................................. 57

4.4.3.1 Pré-tratamento com dexametasona..................................................................... 57

4.4.3.2 Pós-tratamento com dexametasona........................................................................ 60

4.4.4 Participação dos produtos originados pela via das ciclooxigenases na interação leucócito-endotélio induzida por VBj............................................. 60

4.4.5 Participação dos produtos originados pela via das ciclooxigenase-2 na interação leucócito-endotélio induzida por VBj................................................ 63

4.4.6 Participação dos produtos originados pela via lipoxigenase na interação leucócito-endotélio induzida por VBj................................................................... 63

4.4.7 Participação do fator de necrose tumoral- $\alpha$ na interação leucócito-endotélio induzido por VBj................................................................................................. 66

4.4.8 Participação do óxido nítrico sintase na interação leucócito-endotélio induzido por $\mathrm{VBj}$.

4.4.9 Participação do óxido nítrico sintase indizível na interação leucócito-

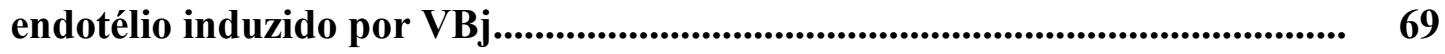

4.5 Soroneutralização........................................................................................................

4.5.1 Interação leucócito-endotélio induzida por $\mathrm{VBj}$ em animais pré-tratados com soro antibotrópico................................................................................................. 72

4.5.2 Interação leucócito-endotélio induzida por $\mathrm{SAB}$, fenol e $\mathrm{SAB}$ sem fenol ........ 74

4.5.3 Participação da histamina na reação induzida pelo SAB ou fenol..................... 77 
4.5.4 Soroneutralização pelo SAB sem fenol......................................................... 77

4.5.4.1 Pré-tratamento de SAB sem fenol.............................................................................. 77

4.5.4.2 Pós-tratamento de SAB sem fenol..................................................................... 80

4.6 Associação farmacológica de dexametasona com SAB com fenol .................... 80

5 DISCUSSÃO

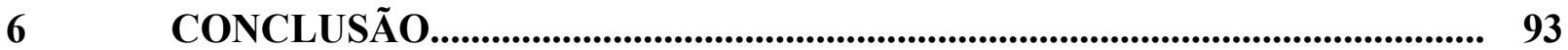

REFERÊNCIAS BIBLIOGRÁFICAS................................................................................... 94 



\section{INTRODUÇÃO}

No Brasil, os acidentes ofídicos representam um problema de Saúde Pública, devido a sua gravidade e freqüência - cerca de 25.000 casos notificados ao ano. Destes, cerca de $90 \%$ são causadas por serpentes do gênero Bothrops (Ministério da Saúde, 2001). Esse gênero compreende mais de 30 espécies e subespécies que estão distribuídas do Sul do México até a Argentina e em algumas ilhas do Caribe. Em nosso país, esse gênero compreende várias espécies, dentre as quais estão as serpentes popularmente conhecidas como jararaca (Bothrops jararaca) (Figura 1), jararacussu (Bothrops jararacussu), urutu cruzeiro (Bothrops alternatus), jararaca pintada (Bothrops neuwiedi), caissaca (Bothrops moojeni) (Melgarejo, 2003).

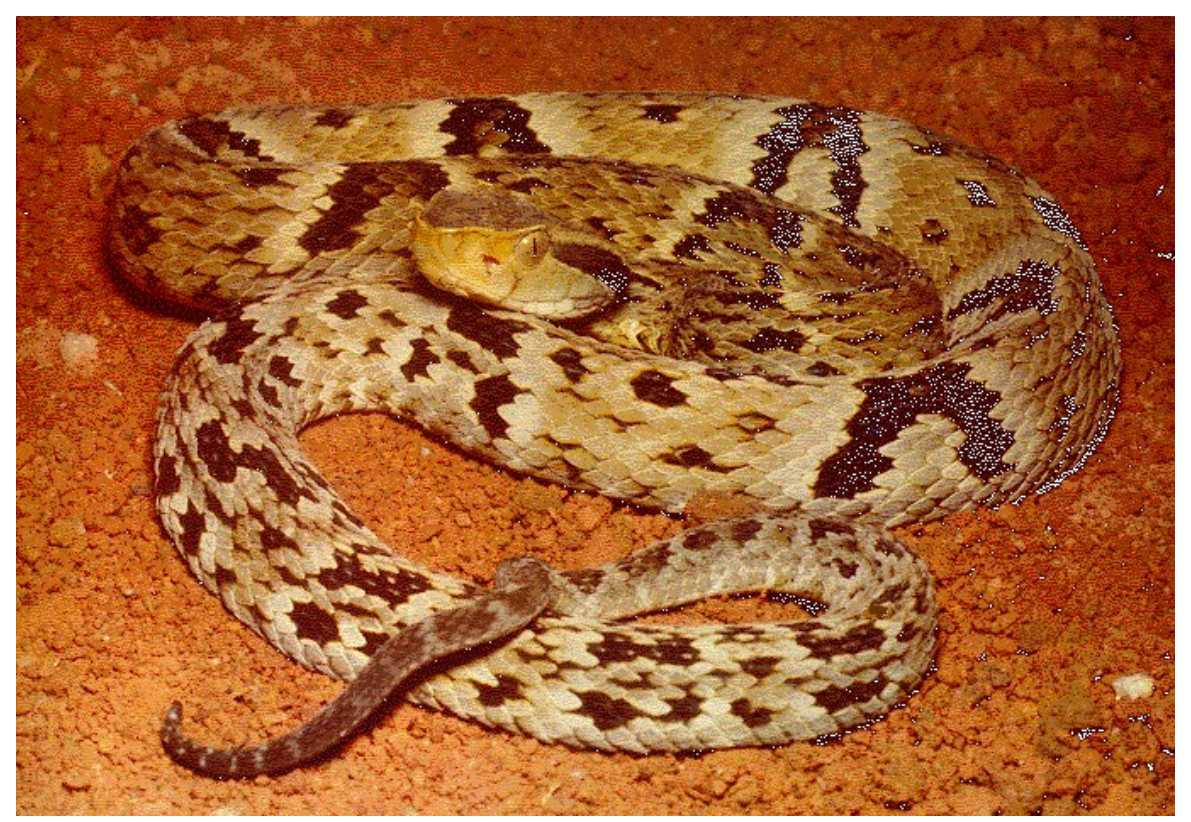

Figura 1. Serpente Bothrops jararaca

Nos envenenamentos botrópicos ocorrem sérios distúrbios hemostáticos e intensa reação inflamatória no local da picada, com a presença de edema e dor, além de hemorragia, podendo haver necrose, resultando em graves perdas teciduais com seqüelas que podem desabilitar o indivíduo ao trabalho (Rosenfeld, 1971; Cardoso et al., 1993; França e Málaque, 2003).

O veneno de Bothrops jararaca afeta a coagulação sangüínea atuando diretamente sobre o fibrinogênio, sobre outros fatores da coagulação e sobre a agregação plaquetária. As toxinas que atuam sobre o fibrinogênio, chamadas de "tipo-trombina", são serinoproteases que hidrolisam somente a região $\mathrm{N}$-terminal da cadeia $\mathrm{A} \alpha$ do fibrinogênio, liberando apenas o 
fibrinopeptídeo A (Hessell e Blomback, 1971), diferentemente do que ocorre com a trombina endógena que atua também na cadeia $\mathrm{B} \beta$ do fibrinogênio, liberando o fibrinopeptídeo B. Este veneno também possui toxinas pró-coagulantes, classificadas como metaloproteases, que atuam sobre os fatores II e X da coagulação, levando à formação de trombina endógena (Denson e Rousseau, 1970; Furukawa e Hayashi, 1977). Metaloproteases hemorrágicas também podem contribuir para os distúrbios de coagulação, por possuírem uma ação fibrinogenolítica (Maruyama et al., 1992; Kamiguti et al., 1994) e por inibirem a agregação plaquetária (Kamiguti et al., 1996). Além destas toxinas proteolíticas, os venenos botrópicos possuem fosfolipases $\mathrm{A}_{2}$ que podem apresentar atividade anticoagulante (Alvarado e Gutiérrez, 1988) e lectinas com atividade antitrombina (Zingali et al., 1993).

Toxinas responsáveis por reações locais específicas, tais como hemorragia e miotoxicidade, também são bem caracterizadas. As hemorragias locais são causadas por metaloproteases dependentes de zinco, agrupadas na família das SVMP (snake venom metalloproteases) (Bjarnason e Fox, 1994). De acordo com sua estrutura molecular, estes fatores hemorrágicos são divididos em 4 classes. A classe P1 possui apenas um pró-domínio e um domínio catalítico; a P2 apresenta um pró-dominio, um domínio catalítico e um domínio disintegrina. A classe P3 apresenta, além destes, um domínio rico em cisteína e, finalmente, a classe P4 apresenta ainda um domínio tipo lectina (Fox e Serrano, 2005; Ramos e Selistre Araújo, 2006).

Nove destas metaloproteases hemorrágicas foram isoladas do veneno de $B$. jararaca (Mandelbaum et al., 1976; 1982; Paine et al., 1992; Maruyama et al., 1992; 1993). Destas, a melhor caracterizada até o momento é a jararagina (Paine et al., 1992), uma metaloprotease que contém um domínio ECD-disintegrina e um domínio rico em cisteína, sendo, portanto classificada como uma P3. Essa toxina apresenta homologia com enzimas proteolíticas da família ADAM (a disintegrin and metalloproteinase), dentre as quais se encontra a TACE (TNF-converting enzyme). Estudos demonstram que a jararagina pode processar o precursor do fator de necrose tumoral- $\alpha$ (TNF- $\alpha$ ) (Moura da Silva et al., 1996). Além disso, essa toxina pode inibir a agregação plaquetária induzida por colágeno (Kamiguti et al., 1996) e hidrolisar o fibrinogênio (Kamiguti et al., 1994).

A morfologia da lesão hemorrágica é variada podendo se observar hemorragia per rhexis, quando ocorre ruptura de células endoteliais com saída de eritrócitos (Ownby et al., 1978; Moreira et al., 1994), ou hemorragia per diapedesis, quando os eritrócitos saem dos vasos por entre as junções interendoteliais, sem lesão aparente de células endoteliais 
(Gonçalves e Mariano, 2000). Em ambos os casos, a ação hemorrágica local é extremamente rápida e existem evidências de que a hemorragia local induzida pelo veneno de Bothrops jararaca seja parcialmente mediada por serotonina e por mediadores de origem neurogênica (Gonçalves e Mariano, 2000).

A hemorragia é um evento que ocorre rapidamente após o contato do veneno com o tecido. Um minuto após a injeção subcutânea de uma dose baixa de veneno de Bothrops jararaca na bolsa escrotal de ratos, já se observam alterações importantes no tecido conjuntivo, tais como desestruturação de fibras colágenas próximas a vasos e feixes nervosos, desgranulação de mastócitos e hemorragia (Gonçalves e Mariano, 2000). Estudos de microscopia intravital demonstram que o veneno botrópico atua na microcirculação, inicialmente induzindo alterações de calibre e permeabilidade de vênulas, seguindo-se pelo aparecimento de microcoágulos, aumento da interação leucócito-endotélio e aparecimento de focos hemorrágicos, preferencialmente em vênulas pós-capilares, mas também presentes em capilares (Farsky et al., 1999).

Lesões musculares podem ser causadas diretamente, pela ação de miotoxinas, ou indiretamente, como conseqüência da isquemia resultante de distúrbios vasculares. As miotoxinas isoladas até o momento possuem estrutura de fosfolipases $A_{2}$, podendo ou não apresentar atividade enzimática (Gutiérrez e Lomonte, 1995). Nem todas as fosfolipases $\mathrm{A}_{2}$ de venenos possuem atividade miotóxica. O veneno de Bothrops jararaca possui fosfolipases (Serrano et al., 1999), porém não possui quantidade significativa de miotoxinas (Moura da Silva et al., 1991).

Diferentemente dos efeitos descritos acima, a reação inflamatória local observada em envenenamentos botrópicos não é causada apenas por uma toxina isolada, e sim por um efeito somatório ou sinérgico de diferentes toxinas e enzimas presente nestes venenos. Gutiérrez e Lomonte (1989) relacionaram componentes de venenos botrópicos que poderiam contribuir para a resposta inflamatória, particularmente para o edema. São eles: 1) toxinas hemorrágicas que, rompendo vasos da microcirculação, induzem extravasamento; 2) toxinas que atuam diretamente sobre células endoteliais de capilares e vênulas, aumentando sua permeabilidade; 3) componentes que induzem liberação de histamina de mastócitos; 4) fosfolipases $A_{2}$ que liberam ácido araquidônico a partir dos fosfolipídeos de membrana, levando a produção de prostaglandinas e leucotrienos; 5) proteases que atuam no cininogênio plasmático liberando cininas (bradicinina) e 6) toxinas que atuam sobre componentes da cascata do complemento, particularmente $\mathrm{C}_{3 \mathrm{a}}$ e $\mathrm{C}_{5 \mathrm{a}}$ que participam da reação inflamatória. 
Os venenos botrópicos desencadeiam uma reação inflamatória aguda. Estudos demonstraram que após o envenenamento, os derivados do ácido araquidônico são os principais componentes mediadores da formação do edema induzido pelo veneno da serpente Bothrops jararaca (Trebien e Calixto, 1989; Perales et al., 1992, Gonçalves e Mariano, 2000). Em ratos, aminas vasoativas e adrenoceptores $\alpha_{1}$ e $\alpha_{2}$ também participam desse processo e, aparentemente, a bradicinina não é um dos mediadores responsáveis pelo edema induzindo por esse veneno (Trebien e Calixto, 1989). Diferentemente do observado em ratos, histamina não participa da mediação do edema induzido pelo veneno de $B$. jararaca em camundongos (Perales et al., 1992; Gonçalves e Mariano, 2000).

Quanto ao infiltrado celular inflamatório, Búrigo et al. (1996) demonstraram que este veneno induz reação inflamatória de longa duração quando injetados na cavidade pleural de ratos. Estes autores verificaram que o veneno induz um aumento de fluído e de migração celular para esta cavidade, e que vários mediadores, tais como histamina, serotonina e produtos do ácido araquidônico, participam desse efeito (Búrigo et al.,1996). Farsky et al. (1997) demonstraram que o veneno de B. jararaca induz aumento das concentrações de leucotrieno $\mathrm{B}_{4}$ e tromboxano $\mathrm{A}_{2}$, correlacionando o aumento destes mediadores ao acúmulo de células inflamatórias. Os mesmos autores observaram em estudos in vitro, que o veneno per se não é capaz de induzir a migração orientada de neutrófilos, porém é capaz de induzir a geração de fatores quimiotáticos séricos, derivados do sistema complemento (Farsky et al., 1997).

Outros mediadores endógenos participam do processo inflamatório induzido por veneno botrópico. Dentre eles, podemos citar componentes do sistema complemento (Farsky et al., 2000), óxido nítrico (Guzzo et al., 2000; Zamuner et al., 2001) e citocinas, como o TNF- $\alpha$, interleucina (IL)-1 $\beta$ e IL-6 (Lomonte et al., 1993; Moura-da-Silva et al., 1996; Petricevich et al., 2000; Rucavado et al., 2002).

\subsection{Inflamação}

A palavra inflamação, do grego phlogosis e do latim flamma, significa fogo, área em chamas. Descrições das características clínicas da inflamação foram encontradas em papiros egípcios, datados de aproximadamente 3000 a.C., mas o primeiro autor a listar os quatro sinais cardinais da inflamação foi Celsius, no século I d.C., que relatou o aumento do fluxo sanguíneo e a dilatação dos pequenos vasos: rubor; a permeabilidade vascular aumentada: 
tumor; que levaria a um aumento na temperatura local: calor, à passagem de células do sangue circulante e dor local: dor (Rocha e Silva e Garcia Leme, 1972). A perda de função, quinto sinal clínico, foi adicionada posteriormente por Virchow.

Em 1793 John Hunter, observou que a inflamação não é uma doença, mas uma resposta inespecífica que tem um efeito salutar sobre seu hospedeiro. No século XX, Thomas Lewis estabeleceu o conceito de que substâncias químicas, como a histamina, induzidas localmente pela lesão, medeiam as alterações vasculares da inflamação. A inflamação é uma resposta protetora cujo objetivo é livrar o organismo da causa inicial da lesão (Kumar et al., 2005). A inflamação por definição é uma reação do tecido vivo vascularizado a uma lesão local, podendo ser aguda ou crônica, dependendo do tipo e persistência do agente lesivo. Esta lesão pode ser ocasionada por estímulos mecânicos, químicos, por invasão de microorganismos ou devido a reações de hipersensibilidade (Kumar et al., 2005). Ao contrário da resposta imune, a inflamação é uma resposta inespecífica e não possui memória (Rankin, 2004), compreendendo eventos vasculares, celulares e linfáticos (Osborn, 1990).

\subsubsection{Mediadores inflamatórios}

É característico da resposta inflamatória aguda, o aumento de fluxo sanguíneo com vasoconstrição no primeiro momento, seguida de uma vasodilatação, causando calor e vermelhidão no local da injúria. Essas alterações levam ao aumento da permeabilidade vascular e conseqüente extravasamento de proteínas plasmáticas, ocasionando a formação do edema e também migração de células inflamatórias para o local da lesão (Kumar et al., 2005).

Estes eventos ocorrem principalmente devido à liberação substâncias endógenas liberadas após o estímulo lesivo, denominadas de mediadores inflamatórios (Saadi et al., 2002). Vários são os mediadores inflamatórios envolvidos nesse processo. Dentre eles, citamos os metabólitos lipídicos derivados do ácido araquidônico, como as prostaglandinas, os leucotrienos e as lipoxinas, gerados a partir de fosfolipídeos de membrana. Além destes, outros mediadores tais como aminas vasoativas, citocinas, entre outros, atuam como importantes moduladores da resposta inflamatória (Cabral et al., 2005).

As aminas vasoativas, histamina e serotonina são os primeiros mediadores a serem liberados no processo inflamatório. A histamina pré-formada está presente em mastócitos e é liberada pela degranulação dessas células em resposta a vários estímulos, causando dilatação das arteríolas e aumento na permeabilidade das vênulas. Na microcirculação ela age por meio 
de sua ligação aos receptores $\mathrm{H}_{1}$ nas células endoteliais. A serotonina (5-hidroxitriptamina) é um mediador semelhante à histamina, sendo liberada por plaquetas quando ocorre agregação plaquetária após contato com colágeno, trombina, difosfato de adenosina (ADP) e complexo antígeno-anticorpo (Kumar et al., 2005). Majno et al (1961), demonstrou que a serotonina atua da mesma forma que a histamina na microcirculação músculo cremaster de ratos, onde foi observado aumento de permeabilidade sanguínea e separação das junções intercelulares das células endoteliais.

Os mediadores lipídicos são produzidos pela a ação da enzima fosfolipase $\mathrm{A}_{2}$ sobre fosfolipídeos de membrana. Principalmente degradando ácido araquidônico liberando seus derivados, os eicosanóides, que são mediadores de diversas condições patológicas especialmente nos processos inflamatórios (Cabral et al., 2005).

O ácido araquidônico pode ser metabolizado pela via da lipoxigenase, que o converte em derivados hidroperóxidos (5-HPETE-ácido hidroperoxieicosatetraenóico) nos leucócitos, dando origem aos leucotrienos (Majno e Joris, 2004). O leucotrieno $\mathrm{B}_{4}$ é um potente agente quimiotático e ativador das respostas dos neutrófilos, tais como adesão ao endotélio vascular, geração de radicais livres e liberação de enzimas lisossomais e os leucotrienos $C_{4}, D_{4}$ e $E_{4}$ causam vasoconstrição, broncoespasmo e aumento da permeabilidade vascular (Kumar et al., 2005). Ainda, o ácido araquidônico pode ser metabolizado pela via das ciclooxigenases, mediada por enzimas que catalisam a biosíntese das prostaglandinas. As ciclooxigenases (COX) possuem duas isoformas distintas, a COX-1 e a COX-2 (Majno e Joris, 2004). A COX-1 é expressa constitutivamente em vários tecidos, e possui um papel citoprotetor importante do estômago, e também está envolvida na sinalização entre células e na homeostase tecidual. A COX-2, por sua vez, não é expressa constitutivamente, não sendo detectada em tecidos não lesados, mas é induzida por células inflamatórias, dando origem a diversos prostanóides, como por exemplo, as prostaglandinas envolvidas nas reações inflamatórias, que são importantes na vasodilatação (Kumar et al., 2005).

As prostaglandinas também estão envolvidas nos processos da dor na inflamação. Estão divididas em séries, com base nas características estruturais, e identificadas por letras e um número subscrito que indica o número de ligações duplas no composto, algumas dessas enzimas apresentam restrição na distribuição tecidual (Kumar et al., 2005). A prostaglandina $\mathrm{E}_{2}\left(\mathrm{PGE}_{2}\right)$, produzida por macrófagos, estimulados, possui efeito vasodilatador que, combinado com outros agentes, causa extravasamento de fluídos para tecidos adjacentes, promovendo o edema. Também participa da mediação da hiperalgesia e da febre. Outro 
derivado, a prostaciclina ( $\mathrm{PGI}_{2}$ ) encontrada na parede dos vasos, além de ser um inibidor de agregação plaquetária, possui efeito vasodilatador e causa aumento do fluxo em vênulas póscapilares (Majno e Joris, 2004). A $\mathrm{PGD}_{2}$ é o principal metabólito da via da ciclooxigenase nos mastócitos e causa vasodilatação e aumento da permeabilidade das vênulas pós-capilares, potencializando o edema (Kumar et al., 2005).

Os mediadores podem agir em um ou em alguns tipos de células, terem vários alvos ou mesmo apresentar efeitos em diferentes tipos celulares, sendo uma vez ativados e liberados pelas células, a maioria desses mediadores têm uma meia-vida curta (Kumar et al., 2005).

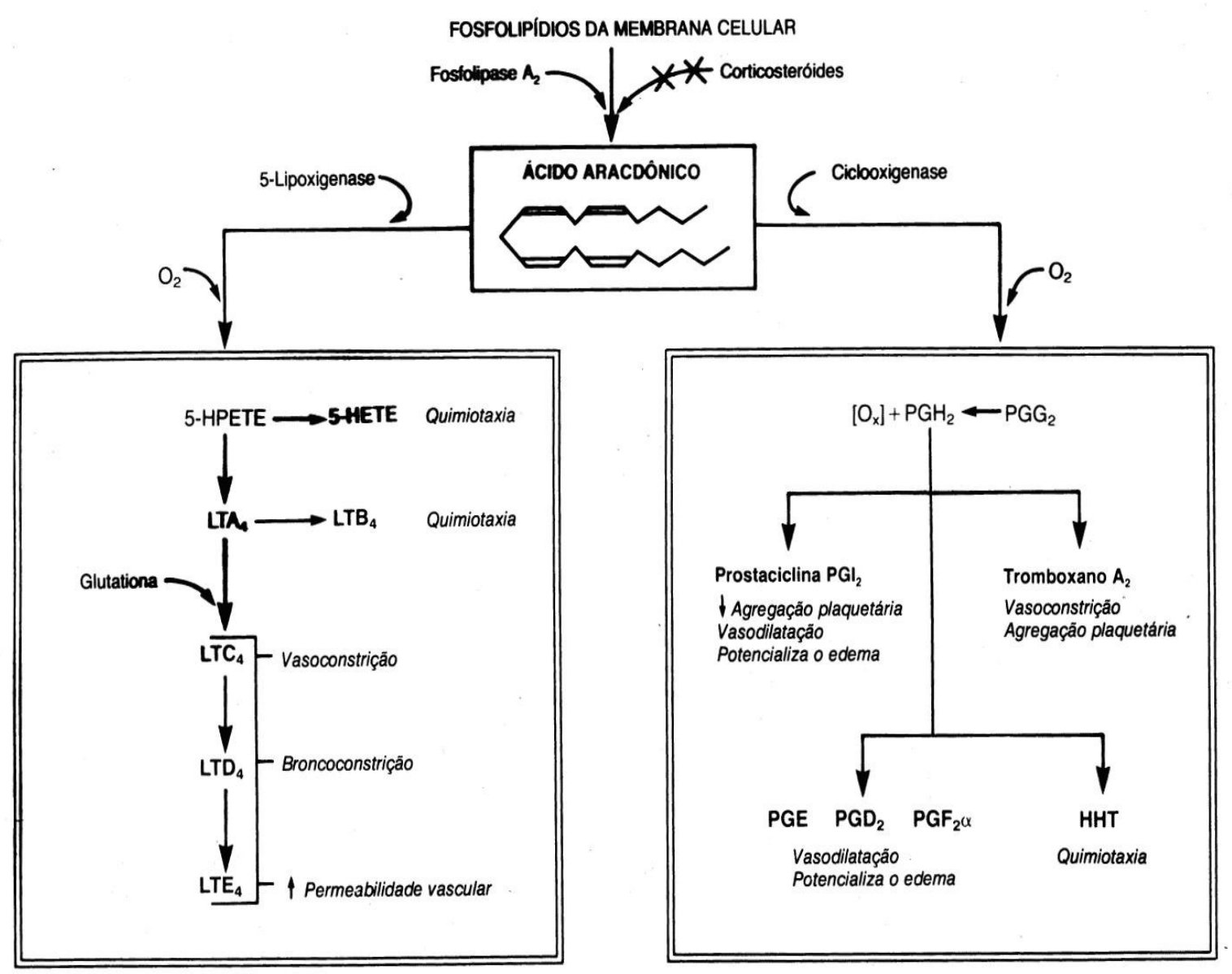

Figura 2. Mediadores químicos derivados de fosfolipídeos (Cotran et al., 1999). 
A secreção de citocinas e quimiocinas amplifica a resposta inflamatória. As citocinas são proteínas produzidas por vários tipos celulares, principalmente linfócitos e macrófagos ativados, mas também por células do endotélio, epitélio e tecido conjuntivo. A IL-1 e o TNF$\alpha$ são as duas principais citocinas que participam do processo inflamatório. No endotélio elas induzem síntese de moléculas de adesão, mediadores químicos, incluindo outras citocinas e quimiocinas, fatores de crescimento, eicosanóides e óxido nítrico (NO), além de produzirem enzimas associadas ao remodelamento da matriz. O TNF também induz o priming dos neutrófilos, levando a um aumento das respostas dessas células a outros mediadores (Kumar et al., 2005).

O óxido nítrico (NO), um mediador pleitrópico da inflamação, é um gás solúvel produzido pelas células endoteliais, pelos macrófagos e por células nervosas, incluindo neurônios e células da glias. O NO é sintetizado a partir da L-arginina pela enzima óxido nítrico sintase (NOS). Existem duas isoformas de NOS: a constitutiva (cNOS), dependente de íons cálcio e de calmodulina, que está envolvida na sinalização celular, e a induzível (iNOS, tipo II), não expressa em condições normais. Essa isoforma é induzida por citocinas e/ou endotoxinas em uma variedade de células, incluindo macrófagos, linfócitos, células endoteliais, neutrófilos e plaquetas (Moncada, et al., 1988). As isoformas constitutivas compreendem a NOS neuronal (nNOS, tipo I), presente em neurônios, e a NOS endotelial (eNOS, tipo III), presente em células endoteliais e plaquetas (Moncada, et al., 1988; Radomnski et al., 1990).

O NO produzido pela eNOS tem papel essencial no processo de relaxamento vascular, que em condições fisiológicas ocorre quando receptores da membrana das células endoteliais são ativados por estímulos solúveis (acetilcolina, bradicinina, serotonina, entre outros) ou quando há um aumento do atrito exercido pelas células circulantes sobre a camada endotelial (Busconi e Michel, 1993). Por outro lado, a ativação da iNOS possui ação citostática e citotóxica, resultante da ação direta ou indireta de outros compostos liberados durante o processo inflamatório. Durante o processo inflamatório ou infeccioso, macrófagos, neutrófilos e células endoteliais ativadas secretam simultaneamente $\mathrm{NO}$ e intermediários reativos de oxigênio. Uma ação tóxica cooperativa de NO e ânion superóxido resulta com esses intermediários na formação de peroxinitrito, um poderoso oxidante de proteínas, aumentando efetivamente a ação tóxica do NO (Dusse et al., 2003).

Adicionalmente, as lipoxinas, mediadores endógenos gerados pela via das lipoxigenases, possuem atividade antiinflamatória. A lipoxina $\mathrm{A}_{4}$ inibe a migração de 


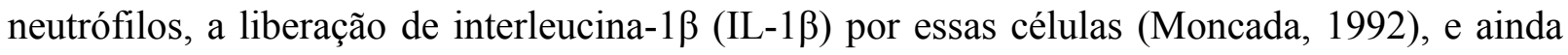
estimula a fagocitose de neutrófilos apoptóticos por macrófagos (Godson et al., 2000). As lipoxinas $\mathrm{A}_{4}$ e $\mathrm{B}_{4}$ são geradas pela ação das enzimas 12-lipoxigenase de plaquetas ou da 15lipoxigenase de macrófagos sobre o leucotrieno $\mathrm{A}_{4}$ liberado pelos neutrófilos (Serhan e Sheppard, 1990; Levy et al., 1993; Bonnans et al., 2002). As principais ações das lipoxinas são inibir o recrutamento leucocitário e os componentes celulares da inflamação, retardando a entrada de novos leucócitos nos locais inflamados. Inibindo a quimiotaxia dos neutrófilos e sua adesão ao endotélio (Kumar et. al., 2005; Serhan e Savill, 2005).

Ainda nos eventos vasculares, deve ser destacada a participação dos seguintes mediadores: os fragmentos C3a e C5a do sistema complemento; os fibrinopeptídeos, oriundos da degradação da fibrina; a bradicinina, proveniente do sistema das cininas, além do fator de ativação plaquetária (PAF) (Kumar et al., 2005).

\subsection{Interação leucócito-endotélio}

A microscopia intravital vem sendo amplamente utilizada para a caracterização de agentes inflamatórios e para pesquisa de novas drogas antiinflamatórias, onde é possível obter informações dos eventos dinâmicos na microvasculatura in vivo. Com esta técnica é possível estudar as interações leucócito-endotélio durante o processo inflamatório, observando os eventos celulares de rolling, adesão e migração, em uma determinada vênula pós-capilar (Gavim e Chatterjee, 2004).

O processo inflamatório depende da migração de células inflamatórias do interior de vênulas para o local da injúria, fenômeno denominado de diapedese. Estas são mediadas por quimiocinas e algumas citocinas, como IL-1 $\beta$ e TNF- $\alpha$, e a saída destas células em vênulas pós-capilares é mediada por moléculas de adesão (Ptzalis et al., 2002). Antes da saída, os leucócitos passam por processos distintos: aumento do número destas células, marginação e diminuição da velocidade com que os leucócitos se deslocam sobre as células endoteliais, processo chamado de rolling; firme adesão de leucócitos em células endoteliais; e subseqüente migração destas células para o tecido extravascular, através das junções de uma única camada de células endoteliais presentes em vênulas pós-capilares (Ebnet e Vestweber, 1999). 


\subsubsection{Rolling}

Após um estímulo inflamatório, vênulas pós-capilares sofrem uma rápida vasoconstrição seguida de uma vasodilatação. Neste período aumenta a expressão de selectinas, moléculas transmembrânicas dependentes de cálcio, expressas na superfície de leucócitos (L-selectina ou CD62L), em grânulos secretores de plaquetas (P-selectinas ou CD62P) ou em células endoteliais (E-selectinas ou CD62E). Estas famílias de moléculas de adesão são responsáveis predominantemente pelo contato inicial dos leucócitos com o endotélio vascular ao longo da margem da vênula (Butcher, 1991, Springer, 1994, Rankin, 2004).

As selectinas possuem domínios que interagem com ligantes de glicoproteína, esta ligação é de baixa afinidade e apresenta uma velocidade de ligação e degradação rápida; essa propriedade permite que as selectinas sejam intermediárias da ligação inicial e subseqüentes rolamento dos leucócitos no endotélio rolamento dos leucócitos no endotélio frente ao sangue que flui (Kumar et al., 2005). A E-selectina interage com os ligantes ESL-1 (E-selectin ligand-1), que contém domínios sialomucina e não são expressos constitutivamente. Já a Pselectina é expressa constitutivamente em grânulos secretórios, $\alpha$-grânulos de plaquetas e em corpos de Weibel-Palade em células endoteliais (Modur et al., 1997; Woltmann et al., 2000). A PSGL-1 (P-selectina glycoprotein ligand-1) ou CD24 é o ligante da P-selectina. A Lselectina interage com os ligantes GlyCAM-1 (Glycosylation dependent cell adhesion molecule-1); CD34 e MadCAM (Mucosal addressin cellular adhesion molecule-1) (Ebnet e Vestweber, 1999) A estrutura básica de todos estes ligantes é modificada pelos carboidratos específicos que são reconhecidos pelas selectinas.

As selectinas começam, mas não mantém as interações. Vários estímulos são necessários para ativar os leucócitos e a superfície endotelial., com conseqüente adesão celular e subseqüente migração pela barreira endotelial.

Em experimentos com animais foi demonstrado que, com a expressão de E-selectina em células endoteliais, as integrinas CD18, expressas em leucócitos, induzem a diminuição da velocidade do rolling. Essa diminuição ou lentidão no rolamento contribui para o processo de contato do leucócito ao endotélio, necessário para ocorrer a firme adesão (Rankin, 2004). 


\subsubsection{Firme adesão}

A expressão de integrinas resulta em uma maior interação leucócito-endotélio, primeiro passo antes do processo de diapedese de células inflamatórias. A expressão destas moléculas se inicia por estímulos de quimiocinas e mediadores inflamatórios (Rampart, 1994). As integrinas coordenam os sinais dos ligantes extracelulares com as respostas das células dependentes do citoesqueleto, ou seja, motilidade, mudança de formato e fagocitose (Kumar et al., 2005).

As integrinas representam a família transmembrânica heterodimérica de glicoproteínas, compostas pela subunidade $\alpha$, também conhecida como CD11, e subunidade $\beta$, como $\mathrm{CD18}$, unidas por ligações não covalentes. Estas subunidades possuem um longo domínio transmembrânico e um domínio citoplasmático curto associado a proteínas do citoesqueleto (Hynes, 1992). O complexo CD11/CD18 é responsável pela firme adesão do leucócito ao endotélio (Rankin, 2004). Este complexo se liga aos seus respectivos ligantes denominados famílias das imunoglobulinas, representadas por: ICAM-1 (intercellular adhesion molecule-1), ICAM-2 ou VCAM-1 (vascular cell adhesion molecule-1).

A ICAM-1 (CD54) é uma proteína expressa em baixos níveis por células endoteliais vasculares, tendo sua expressão aumentada nestas células, pela ação da IL-1, TNF- $\alpha$ e do interferon- $\gamma$ (INF- $\gamma$ ). Já a ICAM-2 (CD102) é expressa constitutivamente em células endoteliais. A VCAM-1 é expressa em neutrófilos e interage com seu ligante VLA-4, expresso nas células endoteliais. A VCAM-1 também participa da adesão de linfócitos, monócitos, eosinófilos e basófilos (Dansky et al., 2001). A expressão destas moléculas são essências para a conversão de rolling em adesão. 


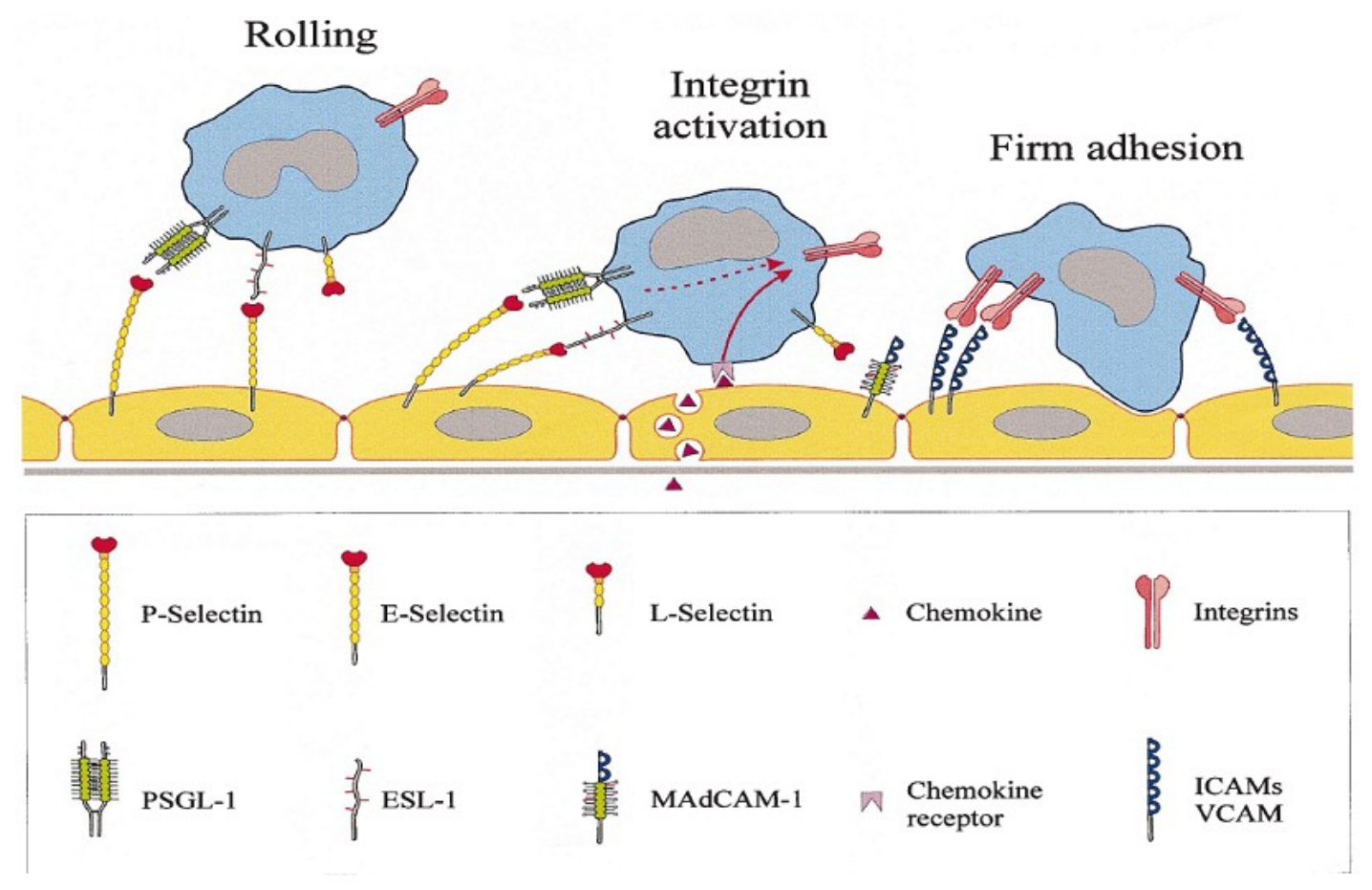

Figura 3. Cascata de múltiplas interações de moléculas de adesão (modificado de Ebnet e Vestweber, 1999).

\subsubsection{Migração celular}

Após a adesão celular, os leucócitos emitem pseudópodes entre as junções das células endoteliais, atravessam a membrana basal e finalmente migram para o tecido extravascular em direção ao foco inflamatório (Oda et al., 1995). Essa migração direcionada é um processo chamado de quimiotaxia, que envolve a interação de agentes quimiotáticos com receptores específicos, presentes nas membranas de leucócitos (Kumar et al., 2005).

As quimiocinas possuem papel fundamental para a migração através de vênulas póscapilares, elas estão envolvidas em vários processos fisiopatológicos, tais como estímulo da angiogênese, disseminação de tumores, choque séptico, interação leucócito-endotélio, agindo nos leucócitos aderidos e estimulando as células a migrarem através dos espaços endoteliais na direção do gradiente quimiotático (Kumar et al., 2005).

A IL-8 é descrita como uma citocina estimulante de células endoteliais e de matriz sub-endotelial, formando um gradiente para a migração de neutrófilos (Huber et al., 1991). Similarmente, a IL-1 estimula células endoteliais na forma de MCP-1 (monocyte chemoattractant protein-1) solúvel que promove a migração de monócitos (Randolph e 
Furier, 1995). Dentre as moléculas de adesão, a PECAM-1 (platelet endothelial cell adhesion molecule-1 ou CD31), é a principal envolvida na migração dos leucócitos, pois está presente na junção intercelular do endotélio (Kumar et al., 2005).

A diapedese dos leucócitos, semelhantes a permeabilidade vascular, ocorre predominantemente nas vênulas pós-capilares, exceto nos pulmões, onde ocorre nos capilares. As células direcionadas ao local da injúria são principalmente os neutrófilos e células mononucleares, cuja intenção é eliminar o agente lesivo ou debris celulares, no sentido de efetuar a resolução do processo inflamatório (Majno e Joris, 2004).

\subsection{Resolução da inflamação}

A resposta inflamatória é um processo fisiológico, que inclui a liberação de substâncias pró - e antiinflamatórias pelo organismo afetado, na tentativa de regular o processo, retornando a homeostasia. (Cabral et al., 2005). A resolução completa do processo inflamatório ocorre com a neutralização ou degradação de mediadores, com o retorno da permeabilidade vascular a condições fisiológicas, com o término da infiltração leucocitária e da apoptose de neutrófilos e com a remoção de líquido e proteínas do edema, de leucócitos, de agentes estranhos e de fragmentos necróticos do local.

Alguns mediadores gerados a partir do ácido araquidônico podem estar envolvidos nesta resolução, como as lipoxinas, que possuem uma relação inversa entre a quantidade de leucotrienos formados, sugerindo que as lipoxinas possam ser reguladores negativos da ação dos leucotrienos, um potente agente quimiotático (Serhan e Savill, 2005). As resolvins, uma nova classe de mediadores derivados do ácido araquidônico, também estão envolvidas neste processo de resolução. Elas inibem o recrutamento e ativação dos leucócitos, em parte através da inibição das citocinas (Kumar et. al., 2005; Serhan e Savill, 2005).

Os vasos linfáticos e as células fagocitárias participam desses eventos, tendo como conseqüência reparo e substituição do tecido lesado (Kumar et al., 2005).

No entanto, estes eventos podem causar danos ao organismo quando a resolução do processo inflamatório não é satisfatória. Pode ocorrer substituição de tecido por fibrose, formação de abscesso ou progressão dessa resposta para uma inflamação crônica (Cabral et al., 2005). 


\subsection{Fármacos antiinflamatórios}

A homeostasia tecidual é restabelecida quando a inflamação é limitada por respostas antiinflamatórias, intrínsecas ao organismo, que são rápidas, reversíveis, localizadas, adaptativas a mudanças na origem e integradas ao sistema nervoso (Tracey et al., 2002; Nathan et al., 2002). Quando as forças de contenção intrínsecas falham ou não são suficientes faz-se uso de auxiliares extrínsecos, substâncias que quando administradas ao organismo possuem ação antiinflamatória e atuam na recuperação da homeostasia corpórea (Rang et al., 2004).

Os principais fármacos antiinflamatórios são os glicocorticóides (esteróides) que inibem tanto manifestações iniciais quanto tardias da inflamação, e os fármacos nãoesteróidais, que estão entre os mais utilizados no mundo atualmente (Rang et al., 2004).

Os fármacos antiinflamatórios esteroidais, como a dexametasona, após penetrarem nas células, ligam-se a receptores específicos de alta afinidade Após esta interação, o receptor ativado migra para o núcleo e liga-se a elementos de resposta aos esteróides no DNA. O efeito consiste em repressão ou indução da transcrição gênica. A repressão é obtida através da inibição da ação de fatores de transcrição como AP-1 (activator protein-1) e NF-kB (nuclear factor-kappa B), que inibem os genes da COX-2, de várias citocinas e fatores de moléculas de adesão, bem como a iNOS (Rang et al.,2004). Já o efeito indutível promove o aumento da síntese de uma proteína, a lipocortina-1 ou anexina-1, que tem efeito inibitório sobre a expressão da fosfolipase $\mathrm{A}_{2}$, como conseqüência há uma diminuição na produção de produtos derivados do ácido araquidônico, tanto os gerados pela via ciclooxigenase, como os da via lipoxigenase (Czock et al., 2005).

Os fármacos antiinflamatórios não esteróidais (AINEs) vem sendo utilizados amplamente, a fim de inibir seletivamente a ação de determinados mediadores químicos inflamatórios, assim existem uma lista de mais de 50 AINEs diferentes no mercado para controlar ou modificar os sinais e sintomas da inflamação.

A indometacina é um exemplo de AINEs, que inibe as enzimas COX-1 e COX-2 impedindo dessa forma a síntese de prostanóides e tromboxanos (Rang et al., 2004). O celecoxib é outro antiinflamatório que possui efeito seletivo, inibindo especificamente a COX-2, que impede conseqüentemente a síntese de prostaglandinas, evitando assim, reações adversas que afetam particularmente o trato gastrointestinal como à observada com o uso de um antiinflamatório não seletivo para ciclooxigenase (Rang et al., 2004). Além disso, existem 
fármacos derivados da planta Larrea divaricata que atuam inibindo a via da 5-lipoxigenase e possuem uma potente ação antioxidante, como é o caso do ácido nordiidroguaiarético (NDGA- Nordihydroguaiaretic acid) (Werz, 2007).

Outros fármacos podem influenciar a ação de receptores de mediadores químicos específicos, por exemplo, a metissergida, que atua como um antagonista específico dos receptores de serotonina $\left(5-\mathrm{HT}_{2}\right)$, e a prometazina, que atua como um antagonista dos receptores do tipo $\mathrm{H}_{1}$ da histamina, reduzindo o aumento de permeabilidade vascular e reações alérgicas (Rang et al., 2004).

Ainda, outros fármacos podem atuar como inibidores de citocinas, como é o caso da pentoxifelina, um derivado da metilxantina que atua na modulação da produção de TNF- $\alpha$ no nível pré-transcricional (Edwards et al., 1992). O L-N ${ }^{\mathrm{G}}$-nitro arginine methyl ester (L-NAME) é um fármaco antiinflamatório não seletivo que inibe a síntese das enzimas óxido nítrico sintetase (eNOS, iNOS, nNOS). Consistem em análogos da arginina, competindo com a arginina da NOS e, em alguns casos competem também pelo carregador que transporta a arginina nas células endoteliais (Rang et al.,2004). Além destes inibidores, a aminoguanidina também inibe a NOS e apresenta uma seletividade relativa para a isoforma iNOS.

\subsection{Soroterapia}

A eficácia da soroterapia no tratamento dos envenenamentos ofídicos é inquestionável (Warrel, 1992; Fan, 2003). Desde a introdução do tratamento com antivenenos, observou-se uma redução significativa do número de óbitos causados por acidentes ofídicos (Ministério da Saúde, 2001).

A soroterapia específica tem se mostrado altamente eficaz contra a letalidade e no tratamento das alterações sistêmicas induzidas por esses venenos, tanto é que a eficiência do tratamento pode ser monitorada pela reversão do quadro de incoagulabilidade sangüínea (Rosenfeld, 1971; Cardoso et al., 1993; Sano-Martins et al., 1994). A dose de soro empregada no tratamento é determinada de acordo com a sintomatologia do envenenamento, classificada em leve, grave ou moderada (Ministério da Saúde, 2001).

Apesar da eficiência da soroterapia em neutralizar os sintomas sistêmicos, as reações locais induzidas pelos venenos botrópicos nem sempre respondem satisfatoriamente a esse tratamento. Tal fato se deve à rápida manifestação destas reações locais e pelo fato de que os antivenenos não são capazes de reverter às lesões já estabelecidas ou desencadeadas, e nem de neutralizar os mediadores endógenos que participam do processo (Rosenfeld, 1971). O fato de 
a soroterapia ser pouco eficaz no tratamento das reações locais induzidas pelos venenos botrópicos estimula a procura de tratamentos complementares que possibilitem a melhora desse quadro.

A resistência de serpentes e de alguns animais ofiófagos aos efeitos tóxicos dos venenos de algumas serpentes é bastante conhecida (Domont et al., 1991). Vários fatores presentes no sangue de animais têm sido isolados, sendo descritos como fatores antihemorrágicos (Domont et al., 1991; Bjarnason e Fox, 1994; Thwin e Gopalakrishnakone, 1998; Gonçalves e Chudzinski-Tavassi, 2004). No plasma de serpentes Bothrops jararaca foram descritos alguns desses fatores (Tanizaki et al., 1991; Valente et al., 2001; Gonçalves e Chudzinski-Tavassi, 2004). Um deles apresenta homologia com o cininogênio de alta massa molecular encontrado no plasma de mamíferos e, baseado nessa informação, verificou-se que essa proteína do plasma humano também apresenta atividade inibitória sobre metaloproteases hemorrágicas do veneno de B. jararaca (Gonçalves e Chudzinski-Tavassi, 2004).

Alguns estudos sugerem a utilização destes fatores no tratamento de envenenamentos ofídicos (Perez e Sanchez, 1999), ou ainda a utilização de outros inibidores de proteases administrados localmente no tratamento de reações locais induzidas por veneno botrópicos, associados à soroterapia convencional (Gutierrez et al., 1998; Leon et al., 1998). Entretanto, outros trabalhos demonstram que esses inibidores são eficientes somente quando injetados até poucos minutos após o veneno (Escalante et al., 2000) ou quando pré-incubados com o veneno (Rucavado et al., 2004).

A literatura demonstra que o pré-tratamento de animais com antiinflamatórios, principalmente inibidores de fosfolipase $\mathrm{A}_{2}$ e da via da $\mathrm{COX}$, resulta numa redução significante no edema de pata induzido por venenos botrópicos (Trebien e Calixto, 1989; Perales et al.,1992; Gonçalves e Mariano, 2000; De Faria et al.,2001; Barbosa et al., 2003; Guimarães et al., 2004; Araújo et al., 2007).

Apesar das evidências da participação de mediadores endógenos, liberados do tecido no local da inoculação do veneno, a utilização de antiinflamatórios ou outras drogas associadas à soroterapia não é uma prática comum no Brasil (Ministério da Saúde, 2001). 
Em conjunto, os dados apresentados evidenciam que o veneno de Bothrops jararaca é uma mistura complexa de proteínas, peptídeos e toxinas classificadas como serinoproteases, metaloproteases e fosfolipases $\mathrm{A}_{2}$, fatores que podem induzir as reações inflamatórias, contribuindo para a gravidade dos sintomas locais observados nesse envenenamento. Entretanto, a contribuição efetiva de cada uma destas classes de toxinas no efeito inflamatório induzido pelo veneno total não é bem compreendida. Ainda, este veneno possui um efeito rápido e de grande magnitude, devido à liberação de mediadores químicos, que potencializam o efeito inflamatório deste veneno. Desta forma, além de verificar o efeito das três classes de toxinas existente no veneno sobre a interação leucócito-endotélio no processo inflamatório, também foi verificada mediação farmacológica envolvida nesta interação também é de grande relevância. Este estudo permite o entendimento do desencadeamento do processo inflamatório induzido por este veneno, na tentativa de associação de fármacos específicos ao soro antibotrópico, como terapia complementar, uma vez que a soroterapia é pouco eficaz em reverter os efeitos locais causados no envenenamento. 


\section{OBJETIVO}

O objetivo deste trabalho foi caracterizar a contribuição de serinoproteases, metaloproteases e fosfolipases $\mathrm{A}_{2}$ presentes no veneno total de serpentes Bothrops jararaca na interação leucócito-endotélio induzida por este veneno. E a mediação farmacológica desta interação. Foi também objetivo deste trabalho verificar a eficácia da soroterapia, associada ou não à fármacos antiinflamatórios e soroterapia na reversão deste efeito

Para tanto, os seguintes parâmetros foram investigados:

$\checkmark$ Avaliação do efeito do veneno de Bothrops jararaca sobre a interação leucócitoendotélio, em ensaio de microscopia intravital no músculo cremaster de camundongos;

$\checkmark$ Caracterização do envolvimento de serinoproteases, metaloproteases e fosfolipases $\mathrm{A}_{2}$ presentes nesse veneno durante a interação leucócito-endotélio;

Determinação dos mediadores inflamatórios envolvidos nessa interação celular após o envenenamento;

$\checkmark$ Avaliação da interação de antiinflamatórios e soro antibotrópico no tratamento das reações inflamatórias locais induzidas pelo veneno de Bothrops jararaca 


\section{MATERIAL E MÉTODOS}

\subsection{Animais}

Foram utilizados camundongos Swiss albinos machos, pesando entre 23 e $27 \mathrm{~g}$, fornecidos pelo Biotério Central do Instituto Butantan. Os animais foram mantidos no biotério do laboratório, com livre acesso a água filtrada e ração peletizada, por um período mínimo de dois dias antes de serem utilizados nos experimentos. A utilização dos animais seguiu as recomendações éticas da Sociedade Internacional de Toxinologia e do Colégio Brasileiro de Experimentação Animal. Os protocolos experimentais foram aprovados pela Comissão de Ética no Uso de Animais do Instituto Butantan (Protocolo 199/2005).

\subsection{Veneno}

Foi utilizado um veneno liofilizado extraído de vários exemplares adultos de serpentes Bothrops jararaca (VBj), fornecido pelo Laboratório de Herpetologia do Instituto Butantan. $\mathrm{O}$ veneno foi mantido a $-20{ }^{\circ} \mathrm{C}$ e as soluções foram preparadas com salina $(\mathrm{NaCl} 0.15 \mathrm{M})$ estéril, no momento do uso.

\subsection{Soro antibotrópico}

Foi utilizado o soro antibotrópico (SAB) produzido pelo Instituto Butantan. O SAB é obtido pela imunização de cavalos com uma mistura de venenos de serpentes Bothrops jararaca, Bothrops jararacussu, Bothrops moojeni, Bothrops neuwiedii e Bothrops alternatus. Durante o processo de produção, o antiveneno sofre vários tratamentos para a obtenção da fração $\left.\mathrm{F}(\mathrm{ab})_{2}\right)_{2}$ do IgG. O SAB é condicionado em ampolas de $10 \mathrm{~mL}$. Cada mL de SAB neutraliza $5 \mathrm{mg}$ do veneno de referência de serpentes Bothrops jararaca, em testes de soroneutralização realizados em camundongos. $\mathrm{O} \mathrm{SAB}$ foi mantido a $4{ }^{\circ} \mathrm{C}$ até o momento da utilização. Também foi utilizado um soro antibotrópico sem o conservante fenol (SAB sem fenol), mantido nas mesmas condições e com potência semelhante ao SAB. 


\subsection{Inibição das proteases e da fosfolipase $A_{2}$ do $\mathrm{VBj}$}

\subsubsection{Inibição das proteases}

As metaloproteases do VBj foram inibidas pelo tratamento com 1,10-fenantrolina (OF; 1,10-Phenanthroline monohydrate, Sigma Chemical Co., St. Louis, MO), conforme a metodologia descrita por Borkow et al. (1997). Para inibição de serinoproteases foi utilizado fluoreto de fenil-metil-sulfonila (PMSF; Phenyl-methyl-sulfonyl-fluoride, Sigma), conforme a metodologia descrita por Radvanyi e Bon (1982). Amostras de $3 \mathrm{mg}$ de veneno/mL de salina $(\mathrm{NaCl}, 0,15 \mathrm{M})$ foram incubadas com $\mathrm{OF}$ ou com PMSF na concentração final de $2 \mathrm{mM}$, por 1 hora à $37^{\circ} \mathrm{C}$, e dialisados durante toda a noite contra uma solução de $\mathrm{NaCl} 0,03 \mathrm{M}$. Após a diálise, as amostras tratadas foram aliquotadas e congeladas a $-80{ }^{\circ} \mathrm{C}$. Como controle, foram utilizadas soluções de veneno submetidas aos mesmos procedimentos, porém, sem a adição de inibidores. As amostras permaneceram congeladas até o momento do uso.

\subsubsection{Inibição da fosfolipase $\mathrm{A}_{2}$}

Para inibição de fosfolipase $\mathrm{A}_{2}$ foi utilizado $3 \mathrm{mg} / \mathrm{mL}$ de $\mathrm{VBj}$ dissolvido em $1 \mathrm{~mL}$ de Tris/ $\mathrm{HCl} 0,1 \mathrm{M}$ pH 8.0, e $125 \mu \mathrm{L}$ do inibidor Brometo de $p$-bromafenacila ( $p$-BPB; 4Bromophenacyl bromide, Sigma) em solução $1,5 \mathrm{mg} / \mathrm{mL}$ de etanol. Esta mistura foi incubada 24 horas a temperatura ambiente e não foi necessário fazer diálise da solução (Diaz-Oreiro e Gutierrez, 1996). Como controle também foi utilizada uma solução de veneno submetido aos mesmos procedimentos, porém sem a adição do inibidor. As amostras permaneceram congeladas até o momento do uso. 


\subsection{Avaliação do efeito inibitório das atividades das toxinas do VBj}

\subsubsection{Atividade de metaloproteases}

A atividade de metaloproteinases foi avaliada pela ação hemorrágica local do veneno, segundo método descrito por Kondo et al. (1960), adaptado para camundongos por Gutiérrez et al. (1985). Uma dose de 2,5 $\mu \mathrm{g}(0,05 \mathrm{~mL})$ de veneno (bruto ou tratado) foi injetado pela via intradérmica em camundongos previamente tricotomizados. Após 3 horas, os animais foram sacrificados, a pele retirada e a área hemorrágica, medida na face interna da pele, contra uma fonte de luz.

\subsubsection{Atividade de serinoproteinases}

A atividade de serinoproteinases foi avaliada pelo substrato cromogênico BAPNA (N-benzoyl-L-arginine-p-nitroanilide). Quando hidrolisado o substrato libera p-nitroanilide, que possui coloração amarelada, podendo ser estimada colorimetricamente. Uma mistura contendo $400 \mu \mathrm{L}$ Tris/ $\mathrm{HCl}$ 0,05M pH 8.0, e $1000 \mu \mathrm{L}$ de BAPNA $1 \mathrm{mM}$, recebeu $1 \mu \mathrm{g}$ veneno (normal ou tratado), mantendo-se a $37^{\circ} \mathrm{C}$ por 15 minutos. A reação foi bloqueada com 500 $\mu \mathrm{L}$ de ácido acético e, em seguida, efetuou-se a leitura em espectrofotômetro a $405 \mathrm{~nm}$ (Erlanger et al., 1961).

\subsubsection{Atividade enzimática da fosfolipase $\mathbf{A}_{2}$}

A atividade enzimática da fosfolipase $\mathrm{A}_{2}\left(\mathrm{FLA}_{2}\right)$ foi determinada de acordo com o método proposto por Seibert et al. (2006). O veneno tratado e seus respectivos controles foram diluídos serialmente e cada amostra foi avaliada em triplicata. Cinco microlitros dessas amostras foram adicionados a $150 \mu \mathrm{L}$ de reagente $(100 \mathrm{mM} \mathrm{NaCl} ; 10 \mathrm{mM} \mathrm{CaCl} 2 ; 7 \mathrm{mM}$ Triton X 100 lecitina de soja 0,27\%; fenol vermelho 98,8 $\mu \mathrm{M}, \mathrm{pH} 7,6$ ) nos poços de uma 
placa a $37^{\circ} \mathrm{C}$. O registro da reação foi realizado no aparelho Spectramax 190 acoplado a um computador, e as leituras forma realizadas no programa SoftMax Pro 4.8. A diminuição na absorbância $\left(\Delta \mathrm{A}_{558 \mathrm{~nm}}\right)$ foi registrada por 3 minutos para calcular a velocidade máxima (U/min) da reação. Uma unidade da atividade $\mathrm{FLA}_{2}$ foi definida como a quantidade de enzima necessária para determinar a $\Delta \mathrm{A}_{558 \mathrm{~nm}}=1 / \mathrm{min}$ a $558 \mathrm{~nm}$ (Seibert et al., 2006).

\subsection{Avaliação da interação leucócito-endotélio}

Essa interação foi avaliada por ensaios de microscopia intravital. O VBj $(1 \mu \mathrm{g} / 100$ $\mu \mathrm{L})$ e salina $(100 \mu \mathrm{L})$ foram injetados no subcutâneo da bolsa escrotal, e o leito vascular do músculo cremaster foi preparado. Diferentes tratamentos foram associados como descrito posteriormente.

$\mathrm{Na}$ hora do ensaio, após 2 ou 24 h do último tratamento, os camundongos foram anestesiados com uma associação de Cloridrato de Quetamina e Xilazina (8,3mg e 3,3mg/100g de peso corpóreo, respectivamente) e com auxílio de uma tesoura de ponta fina foi realizada a exposição do músculo cremaster e a secção do epidídimo para o desprendimento do músculo cremaster. Após esse procedimento, a preparação foi mantida sobre uma placa com temperatura controlada $\left(37^{\circ} \mathrm{C}\right)$, dotada de uma área transparente, através da qual o leito microvascular é visualizado (Baez et al., 1973). A preparação foi mantida úmida e aquecida por irrigação com solução tampão de Ringer-Locke a $37{ }^{\circ} \mathrm{C}$. A preparação foi analisada em um microscópio de luz (Zeiss Axioskop) com objetiva 10x e acoplado a uma câmera para captação de imagens (JVC TK-C600). As imagens foram transmitidas a um aparelho de televisão ligado a um vídeo cassete $\overline{\bar{z}}$ e a um computador provido de uma placa de captura de vídeo, permitindo a captação de imagens estáticas e dinâmicas, e posterior gravação em DVD. As medições foram feitas com auxílio do programa de análise de imagens KONTRON, KS 300 (Carl Zeiss). 
Uma a três vênulas pós-capilares $(20$ e $40 \mu \mathrm{m})$, com cumprimento de $100 \mu \mathrm{m}$, foram selecionadas em cada animal, sendo analisados os leucócitos em rolling, aderentes e migrados. O rolling foi contado durante um período de $1 \mathrm{~min}$, após $10 \mathrm{~min}$ da exposição da microcirculação. Foram considerados leucócitos aderidos os que estavam estacionados por um tempo $>30$ seg. E a migração celular foi avaliada pela contagem das células presentes em uma distância de até $50 \mu \mathrm{m}$ de cada lado do segmento vascular.

\subsection{Tratamentos farmacológicos e soroterapia}

$\checkmark$ Prometazina (Promethazine hydrochloride, Sigma): inibidor de receptor $\mathrm{H}_{1}, 10 \mathrm{mg} / \mathrm{kg}$, dissolvida em salina estéril e administrada por via i.p. 30 min antes da injeção veneno (Gonçalves e Mariano, 2000);

$\checkmark$ Metissergida (Methysergide maleate salt, Sigma): antagonista de receptor serotoninérico 5HT, $0,8 \mathrm{mg} / \mathrm{kg}$, dissolvida em salina estéril e administrada por via subcutânea (s.c.) 30 min antes da injeção do veneno (Gonçalves e Mariano, 2000);

$\checkmark$ Dexametasona (Decadron ${ }^{\circledR}$ Promade, Brasil): inibidor de fosfolipase $A_{2}, 1,0 \mathrm{mg} / \mathrm{kg}$, dissolvida em salina estéril e administrada por via intraperitoneal (i.p.) $1 \mathrm{~h}$ antes ou $1 \mathrm{~h}$ após a injeção veneno (Gonçalves e Mariano, 2000);

$\checkmark$ Indometacina (Indomethacin, Sigma): inibidor de ciclooxigenase, $3 \mathrm{mg} / \mathrm{kg}$, dissolvida em tampão TRIS 1M, pH 8 , a $37{ }^{\circ} \mathrm{C}$ e solução salina estéril $(1: 10)$. O composto foi administrado por via i.p. 30 min antes da injeção do veneno (Araújo et al., 2007);

$\checkmark$ Celecoxib (Celebra ${ }^{\circledR}$ Pfizer, Brasil): inibidor de ciclooxigenase-2 administrado por via oral 30 min antes da injeção do veneno. Para cada comprimido contendo 200mg adiciona-se $2,5 \mathrm{~mL}$ uma solução de carboximetil (CMC) 1\%, desta solução foi utilizada uma dose de 30mg/kg (Wallace et al., 1999); 
Ácido nordiidroguaiarético (Nordihydroguaiaretic acid - NDGA, Sigma): inibidor 5lipoxygenase administrado por via i.p. 30min antes da injeção do veneno. Para cada 30 $\mathrm{mg} / \mathrm{kg}$ do composto, adicionou-se $2 \mathrm{~mL}$ de solução contendo etanol-salina (1:9), sendo o pH ajustado pra 7,5 com $\mathrm{NaOH} 0,1 \mathrm{~N}$;

$\checkmark$ Pentoxifilina (Pentoxifylline, Sigma): inibidor de fofodiesterase que reduz seletivamente a concentração de mRNA para TNF- $\alpha, 100 \mathrm{mg} / \mathrm{kg}$, dissolvida em salina estéril e administrada por via i.p., 30min antes da injeção do veneno (Edwards et al., 1992);

$\checkmark$ L-NAME (L-N $\mathrm{N}^{\mathrm{G}}$-nitro arginina metil ester, Sigma): inibidor inespecífico da enzima óxido nítrico sintase (NOS), $100 \mathrm{mg} / \mathrm{kg}$, dissolvida em salina estéril e administrada por via s.c. 30min antes da injeção do veneno (Dal Secco et al., 2003);

Aminoguanidina (Aminoguanidine hydrochloride, Sigma): inibidor seletivo da enzima óxido nítrico induzível (iNOS), $50 \mathrm{mg} / \mathrm{kg}$ dissolvida em salina estéril e administrada por via i.p. 30min antes da injeção do veneno (Dal Secco et al., 2003);

$\checkmark$ Soro antibotrópico (SAB) e SAB sem fenol (Instituto Butantan, Brasil): foi administrado $200 \mu \mathrm{L}$ por via endovenosa (i.v.) 30min antes ou 1h após a injeção do veneno.

$\checkmark$ Fenol : foi administrado $200 \mu \mathrm{L}$ de uma solução a $0.25 \%$ por via endovenosa (i.v.)

Os resultados foram comparados aos obtidos em grupos de animais tratados com $\mathrm{NaCl}$ 0,15 M. A prometazina foi associada tanto ao SAB com fenol como ao fenol, e a dexametasona também foi utilizada associada ao SAB pelas mesmas vias especificadas.

\subsection{Análise Estatística}


Os resultados foram expressos como média \pm erro padrão da média (e.p.m.) e analisados estatisticamente pelo ANOVA, seguido pelo teste de Tukey. As análises estatísticas foram determinadas com o programa GraphPad Instat e os resultados foram representados graficamente com a utilização do programa GraphPad Prism software (versão 4.0). Foram considerados significantes os resultados com $p<0,05$. 


\section{RESULTADOS}

\subsection{Cinética dos eventos de interação leucócito-endotélio induzidos pelo VBj}

Quando comparado ao grupo controle, animais injetados com salina, os camundongos injetados com VBj apresentaram diminuição significativa de leucócitos em rolling nos tempos de 30min, 1 e 2h, e um aumento significativo de leucócitos com essa interação $24 \mathrm{~h}$ após a injeção do veneno (Figura 4A). Os animais injetados com VBj apresentaram um aumento marcante de adesão celular em quase todos os tempos estudados, sendo o pico de adesão observado entre a $2^{\mathrm{a}}$ e $4^{\mathrm{a}}$ horas após a injeção do veneno (Figura 4B). Os grupos injetados com $\mathrm{VBj}$ apresentaram o maior número de células migradas na $4^{\mathrm{a}}$ hora, permanecendo esse número alto até a $24^{\mathrm{a}}$ hora e diminuindo significativamente $48 \mathrm{~h}$ após a injeção do veneno (Figura 4C).

\subsection{Atividade inibitória de proteases e da fosfolipase $A_{2}$ do VBj}

Nos testes específicos de avaliação de atividades verificamos que o veneno tratado com $\mathrm{OF}$, inibidor de metaloproteases, apresentou atividade hemorrágica completamente inibida. Os venenos tratados com PMSF, inibidor de serinoproteases, e $p$-BPB, inibidor da fosfolipases $\mathrm{A}_{2}$, apresentaram atividade hemorrágica semelhante ao veneno bruto, indicando que apenas o tratamento com OF inibiu a atividade de metaloproteases do VBj (Tabela 1).

Apenas o veneno tratado com PMSF apresentou inibição aproximadamente a $90 \%$, quando testado sobre o substrato BAPNA. Os venenos submetidos aos outros dois tratamentos apresentaram atividade semelhante ao veneno sem tratamento, indicando uma inibição específica de serinoproteases (Tabela 1). O tratamento com $p$-BPB resultou em 87\% de inibição de atividade fosfolipásica, enquanto os outros tratamentos não alteraram essa atividade quando comparada ao veneno bruto, mostrando uma inibição específica de fosfolipases do VBj (Tabela 1). Também foram feitos controles com a concentração final de álcoois metílico, isopropílico e etílico, diluentes de OF, PMSF e $p$-BPB, respectivamente. Estes tratamentos não alteraram as atividades dos venenos em relação ao veneno bruto, em nenhum dos ensaios avaliados. 

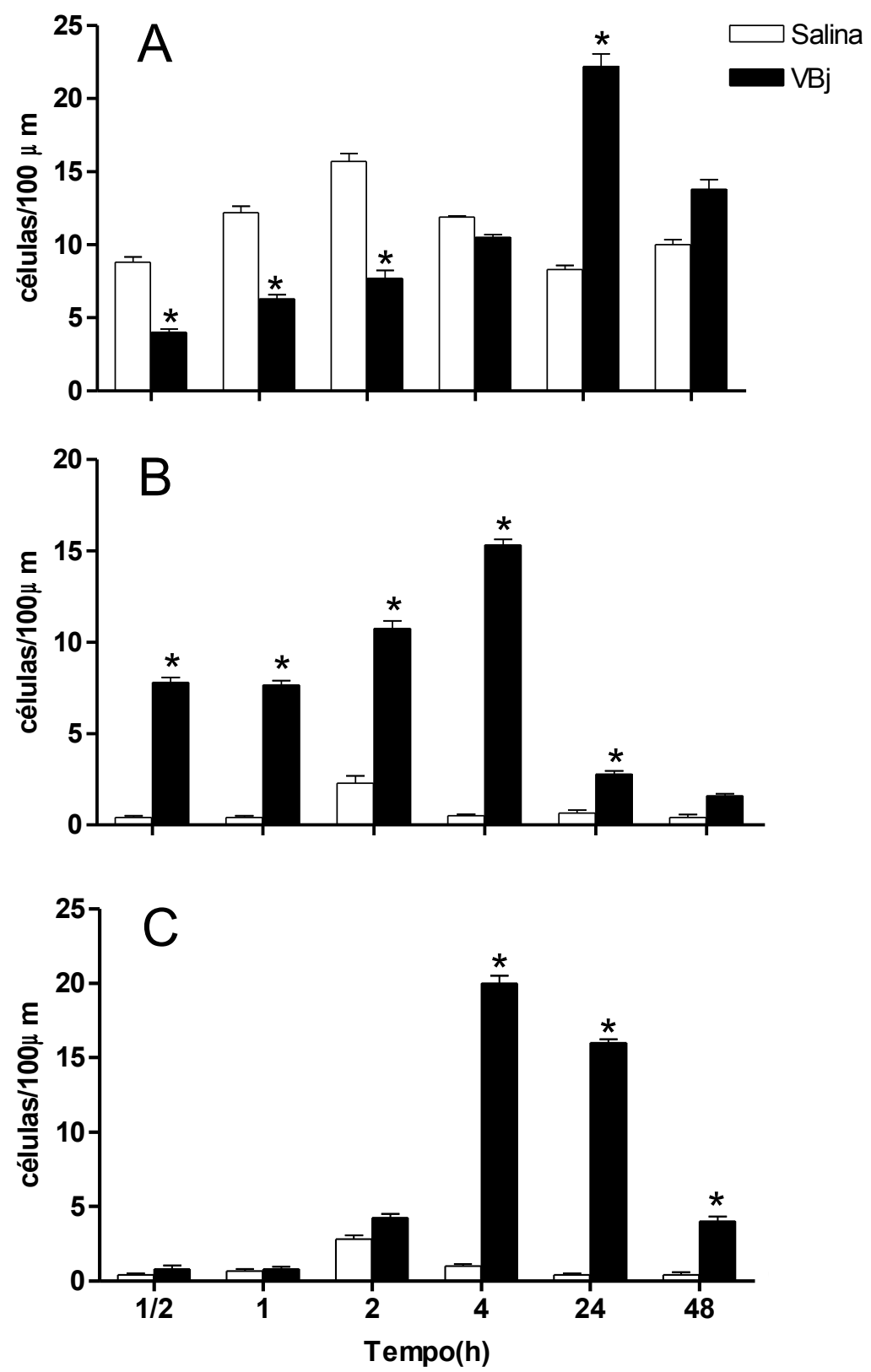

Figura 4 Cinética da interação leucócito-endotélio em vênulas pós-capilares na microcirculação do músculo cremaster de camundongos induzida pelo veneno de Bothrops jararaca $(\mathrm{VBj})$.

Os animais foram injetados com $\operatorname{VBj}(1 \mu \mathrm{g} / 100 \mu \mathrm{L})$ ou salina no subcutâneo da bolsa escrotal. Leucócitos em rolling (A), aderidos (B) e migrados (C) foram analisados em diferentes intervalos de tempo (1/2, 1, 2, 4, 24 ou 48h) após a injeção do veneno. Resultados correspondem à média \pm e.p.m. $\left(\mathrm{n}=5\right.$ animais por grupo). ${ }^{*} \mathrm{p}<0,05$ por comparação ao grupo salina. 
Tabela 1. Avaliação do efeito inibitório de metaloproteases, serinoproteases e de fosfolipase $A_{2}$ $\left(\mathrm{FLA}_{2}\right)$ em ensaios biológicos de atividade hemorrágica, hidrólise com BAPNA e atividade enzimática da $\mathrm{FLA}_{2}$, respectivamente, após tratamento do VBj com OF, PMSF e $p$-BPB.

\begin{tabular}{cccc}
\hline Grupos & Atividade hemorrágica & Hidrólise com & Atividade de FLA 2 \\
& $(\%)$ & BAPNA $(\%)$ & $(\%)$ \\
\hline OF & 0 & 100 & 100 \\
PMSF & 100 & 12 & 100 \\
$p$-BPB & 100 & 100 & 13 \\
\hline
\end{tabular}

OF (1,10-fenantrolina) - inibidor de metaloproteases

PMSF (fluoreto de fenil-metil-sulfonila) - inibidor de serinoproteases

$p$-BPB ( $p$-bromafenacila) - inibidor de fosfolipase $\mathrm{A}_{2}$ 


\subsection{Interações leucócito-endotélio induzidas por VBj com proteases ou FLA $A_{2}$ inibidas}

Utilizando venenos tratados para inibição de proteases ou $\mathrm{FLA}_{2}$ verificou-se que os tratamentos com PMSF ou com $p$-BPB não induziram diferenças nos parâmetros de interação leucócito-endotélio, quando comparados ao grupo injetado com o veneno bruto, após 2 ou 24 h do tratamento (Figuras 6 e 7 , respectivamente).

Já a injeção do veneno tratado com OF resultou em uma diminuição significativa de células aderidas e de células migradas na $2^{\mathrm{a}}$ e na $24^{\mathrm{a}}$ hora, quando comparado com os eventos de interação leucócito-endotélio observados após a injeção do veneno bruto (Figuras 6 e 7 , respectivamente).

\subsection{Mediação farmacológica da interação leucócito-endotélio induzida por VBj}

\subsubsection{Participação da histamina na interação leucócito-endotélio induzida por VBj}

Para se verificar a possível participação da histamina nos eventos de interação leucócito-endotélio induzidos pela injeção de $\mathrm{VBj}$, os animais foram pré-tratados com prometazina, antagonista de receptor $\mathrm{H}_{1}$ de histamina, 30min antes da injeção do veneno.

Os eventos de adesão e migração não apresentaram diferenças estatísticas quando comparado ao grupo injetado com $\mathrm{VBj}$, nos dois tempos estudados (Figura 8A e 8B). Já o número de células em rolling após $2 \mathrm{~h}$ da injeção do veneno pré-tratado com prometazina não apresentou diferenças significantes em relação ao grupo salina, ocorrendo um aumento do número de células em rolling quando comparado com o veneno bruto sem tratamento (Figura 8A). Não foi observada alteração no rolling leucocitário $24 \mathrm{~h}$ após a injeção de prometazina mais veneno, quando comparado com o grupo injetado com veneno não tratado e o grupo controle (Figura 8B). 

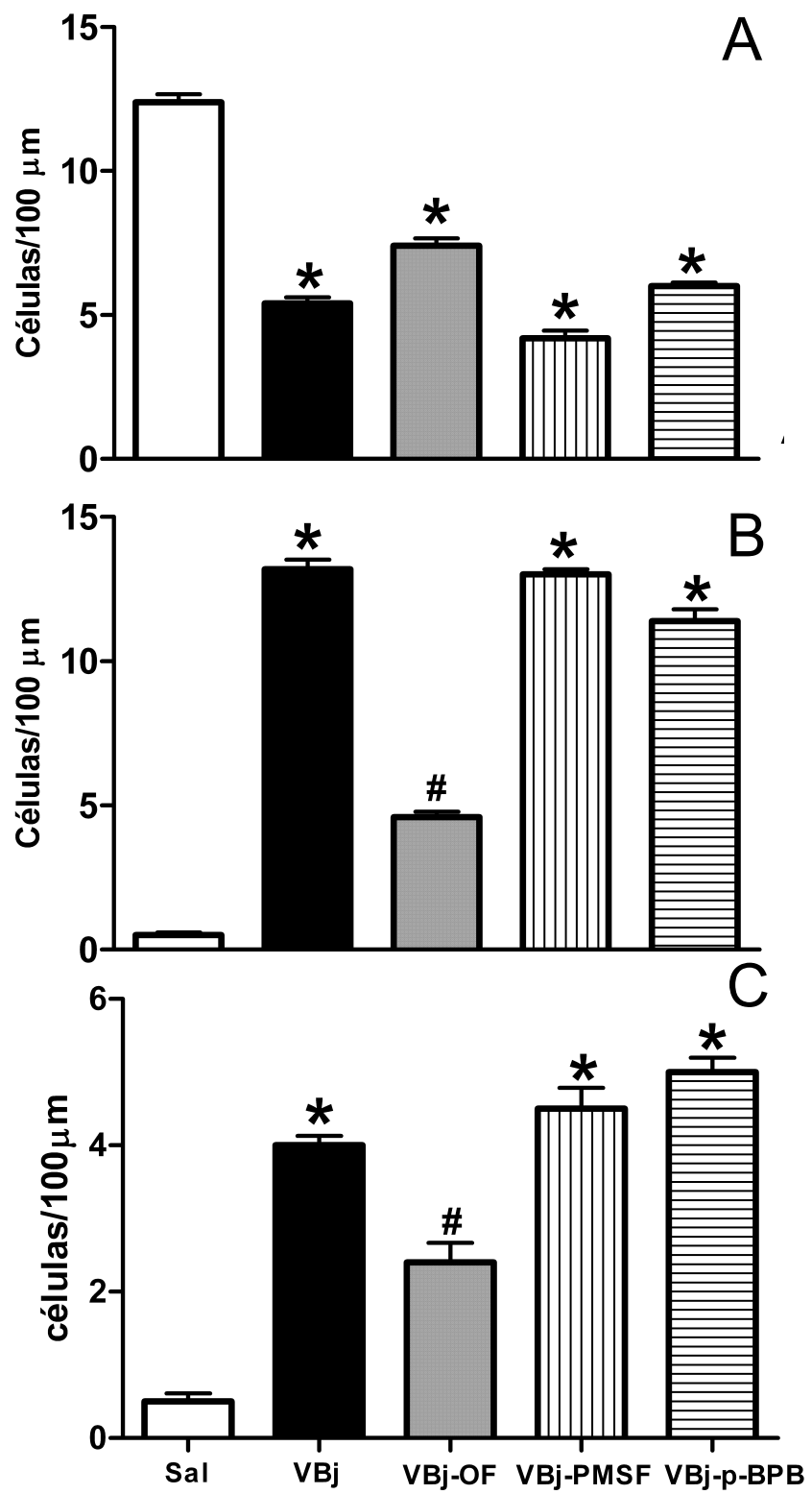

Figura 6. Interação leucócito-endotélio induzida pelo veneno de Bothrops jararaca (VBj) tratado quimicamente com inibidores de proteases e de fosfolipase $A_{2}$.

O VBj foi previamente tratado com OF, PMSF ou $p$-BPB (inibidores de metaloproteases, serinoproteases e fosfolipase $\mathrm{A}_{2}$, respectivamente). Após $2 \mathrm{~h}$ da injeção do VBj tratado ou não tratado $(1 \mu \mathrm{g} / 100 \mu \mathrm{L}$, s.c.) ou da salina (Sal), o cremaster foi exposto e leucócitos em rolling (A), aderidos (B) e migrados (C) foram analisados em vênulas pós-capilares na microcirculação do músculo cremaster de camundongos. Resultados correspondem à média \pm e.p.m. ( $n=5$ animais por grupo). ${ }^{*} \mathrm{p}<0,05$ em comparação ao grupo salina; $\# \mathrm{p}<0.05 \mathrm{em}$ comparação aos outros grupos. 

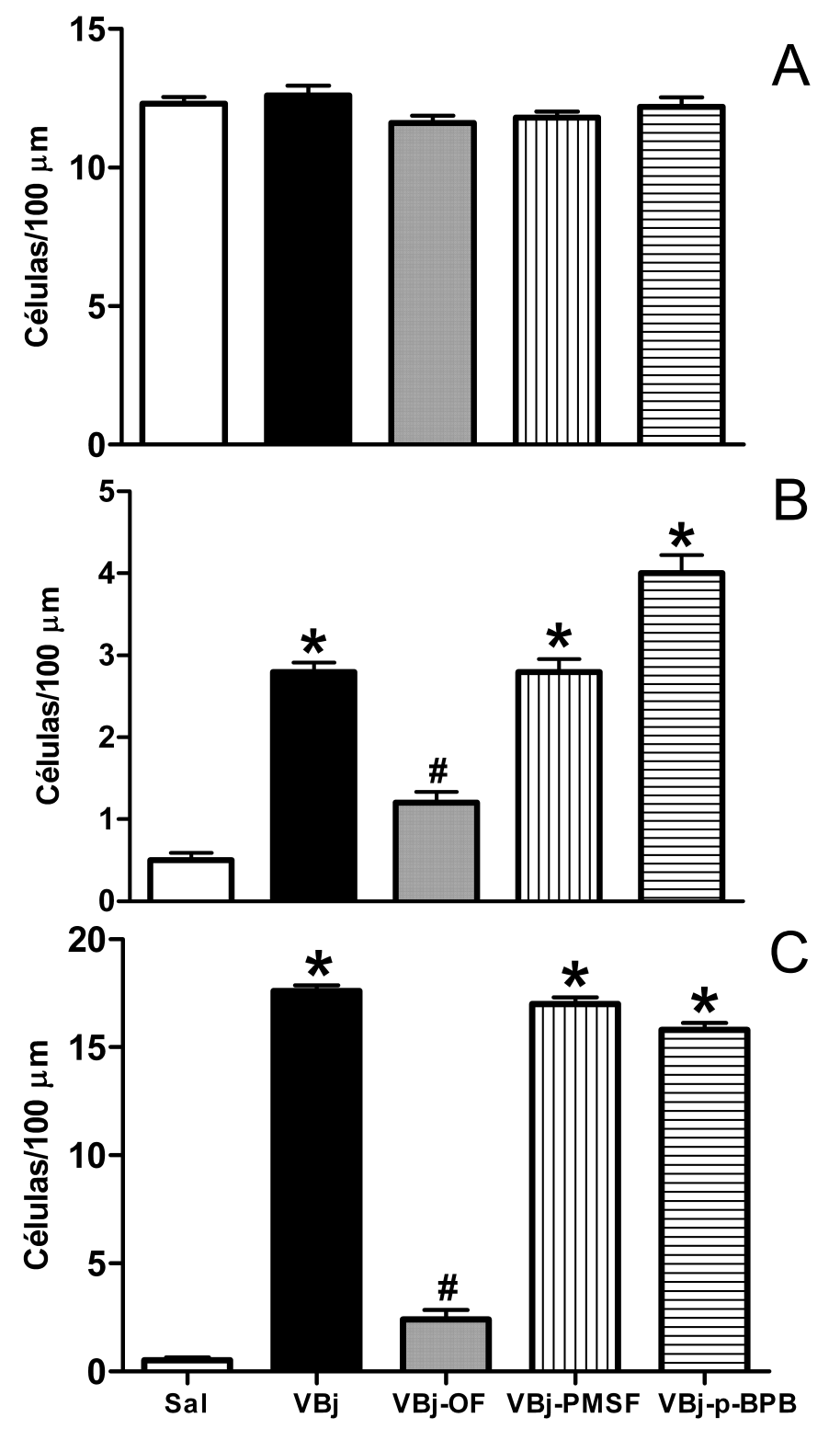

Figura 7. Interação leucócito-endotélio induzida pelo veneno de Bothrops jararaca (VBj) tratado quimicamente com inibidores de proteases e de fosfolipase $A_{2}$.

$\mathrm{O} V \mathrm{Vj}$ foi previamente tratado com OF, PMSF ou $p$-BPB (inibidores de metaloproteases, serinoproteases e fosfolipase $\mathrm{A}_{2}$, respectivamente). Após $24 \mathrm{~h}$ da injeção do $\mathrm{VBj}$ tratado ou não tratado $(1 \mu \mathrm{g} / 100 \mu \mathrm{L}$, s.c.) ou da salina (Sal), o cremaster foi exposto e leucócitos em rolling (A), aderidos (B) e migrados (C) foram analisados em vênulas pós-capilares na microcirculação do músculo cremaster de camundongos. Resultados correspondem à média \pm e.p.m. ( $\mathrm{n}=5$ animais por grupo). ${ }^{*} \mathrm{p}<0,05$ por comparação ao grupo salina; $\# \mathrm{p}<0.05 \mathrm{em}$ comparação aos outros grupos. 

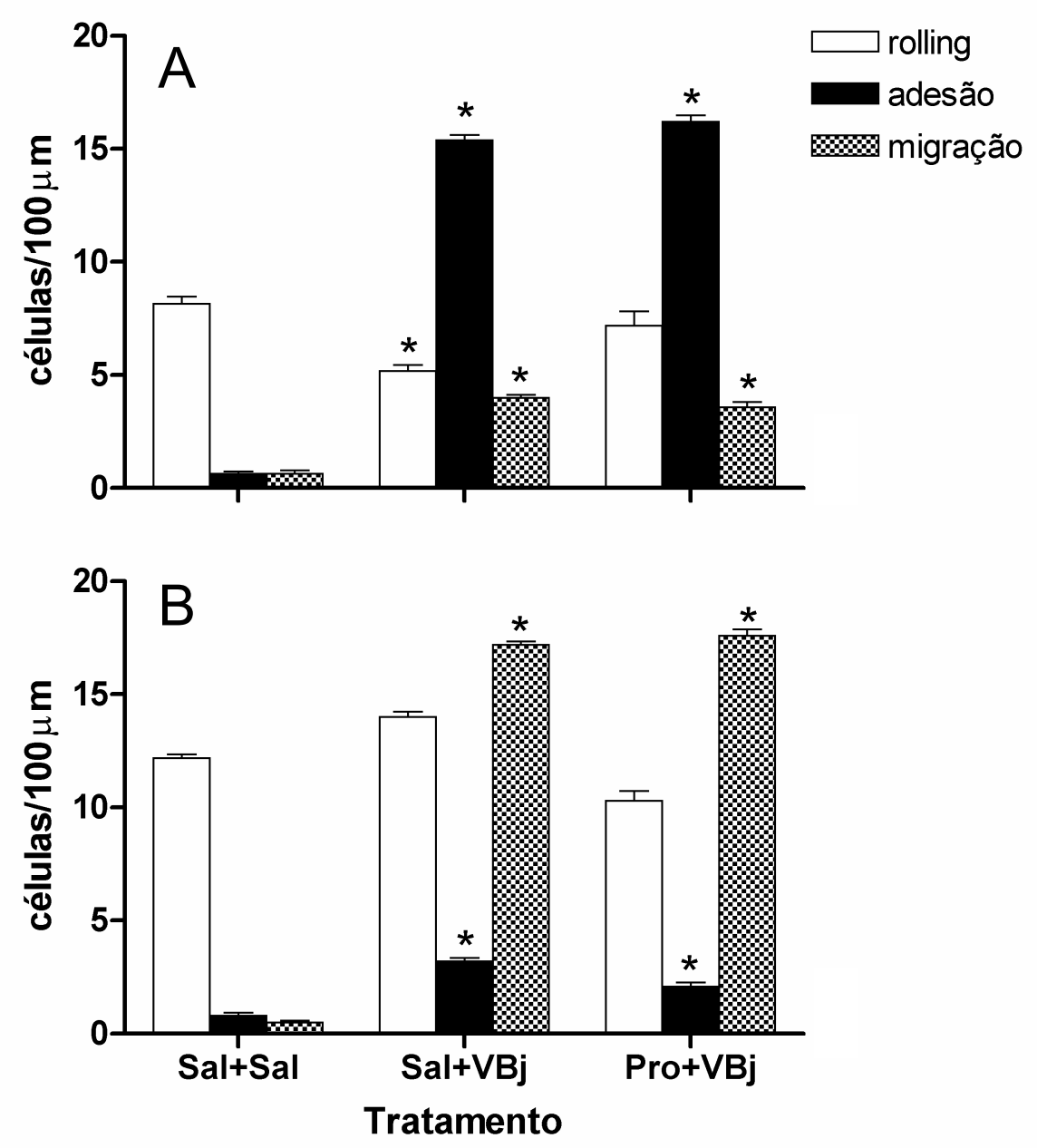

Figura 8. Efeito do pré-tratamento com prometazina (Pro) na interação leucócito-endotélio em vênulas pós-capilares na microcirculação do músculo cremaster de camundongos induzido pelo veneno de Bothrops jararaca (VBj).

Os animais receberam tratamento com prometazina (Pro, $10 \mathrm{mg} / \mathrm{kg}$ ) ou salina (Sal), 30min antes da injeção de $\mathrm{VBj}(1 \mu \mathrm{g} / 100 \mu \mathrm{L})$ ou salina no subcutâneo da bolsa escrotal. Após $2 \mathrm{~h}$ (A) ou 24h (B) da injeção do VBj, o músculo cremaster foi exposto e os eventos celulares (rolling, adesão e migração) foram avaliados por microscopia intravital. Resultados correspondem à média \pm e.p.m. ( $\mathrm{n}=5$ animais por grupo). ${ }^{*} \mathrm{p}<0,05$ por comparação ao grupo controle (Sal+Sal). 


\subsubsection{Participação da serotonina na interação leucócito-endotélio induzida por VBj}

A possível participação da serotonina nos eventos de interação leucócito-endotélio induzidos pela injeção de VBj foi analisada a partir do pré-tratamento com metissergida, inibidor do receptor de serotonina (5-HT $)$, 30min antes da injeção do veneno.

Os parâmetros analisados de adesão e migração celular não foram alterados nos animais tratados quando comparados com o grupo injetado com $\mathrm{VBj}$ bruto, nos dois tempos estudados (Figura 9). Em relação ao número de células em rolling o grupo tratado com metissergida mais veneno apenas na $2^{\text {a }}$ hora avaliada não apresentou diferença quando comparado grupo salina (Figura 9A), entretanto na $24^{\mathrm{a}}$ hora apresentou uma diminuição significante quando comparado ao grupo injetado com salina ou com VBj sem tratamento (Figura 9B).

\subsubsection{Participação dos metabólitos da degradação do ácido araquidônico na interação leucócito-endotélio induzida por VBj}

\subsubsection{Pré-tratamento com dexametasona}

Foi realizado o pré-tratamento com dexametasona (Dx) 1h antes da injeção do veneno, para verificação da participação dos metabólitos da degradação do ácido araquidônico nos eventos de interação leucócito-endotélio induzidos pela injeção de VBj.

O grupo tratado com Dx apresentou um aumento bastante significativo do número de células em rolling após $2 \mathrm{~h}$ da injeção do veneno, quando comparado ao grupo controle e ao grupo injetado com veneno sem tratamento (Figura 10A). Já após 24 h o grupo submetido ao tratamento apresentou uma diminuição bastante considerável, tanto em relação aos animais controle como para o grupo de VBj sem tratamento (Figura 10B).

Em relação à adesão celular o grupo tratado com Dx apresentou uma diminuição significante quando comparado ao grupo injetado com veneno sem tratamento e não apresentou diferença estatística do grupo controle, nos dois tempos analisados (Figura 10). Esta mesma diminuição foi observada no evento de migração celular em relação ao grupo de veneno sem tratamento (Figura 10). 


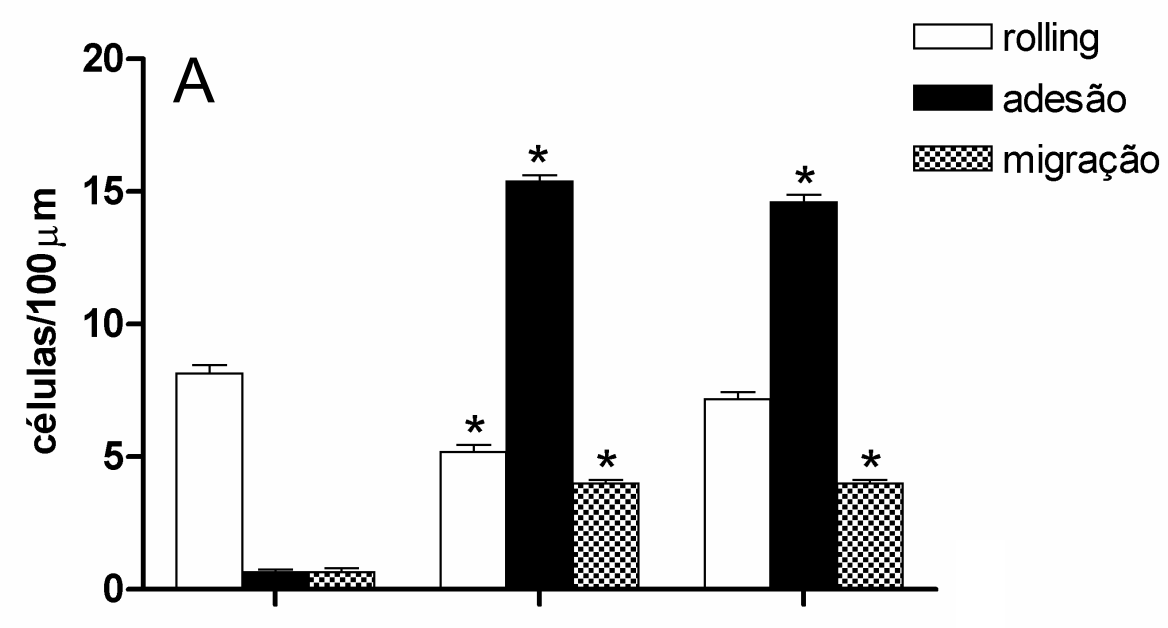

Tratamento

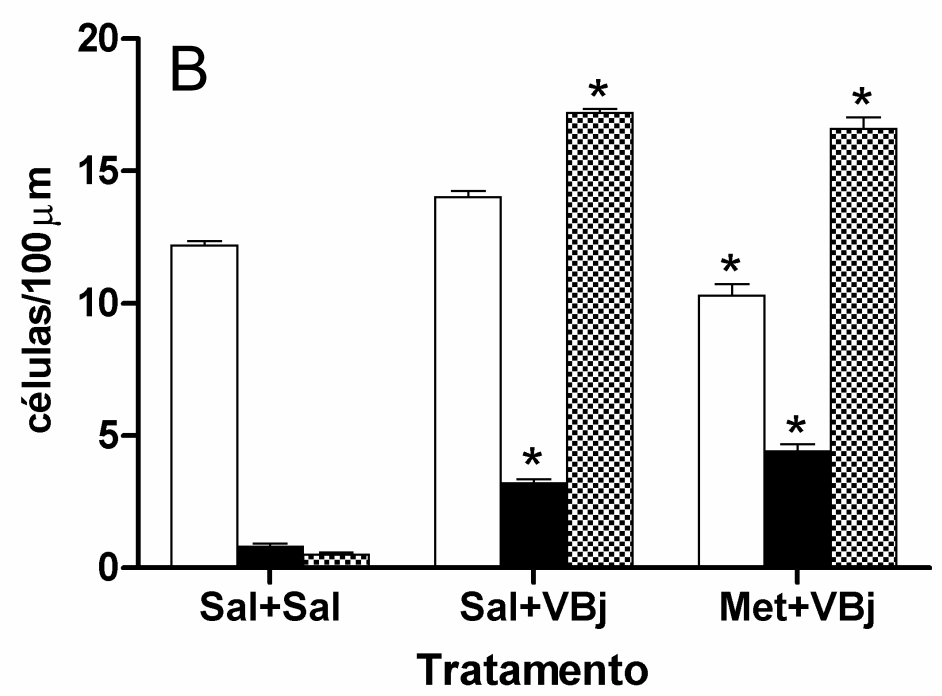

Figura 9. Efeito do pré-tratamento com metissergida (Met) na interação leucócito-endotélio em vênulas pós-capilares na microcirculação do músculo cremaster de camundongos induzido pelo veneno de Bothrops jararaca (VBj).

Os animais receberam tratamento com metissergida (Met, $0,8 \mathrm{mg} / \mathrm{Kg}$ ) ou salina (Sal), 30 min antes da injeção de $\mathrm{VBj}(1 \mu \mathrm{g} / 100 \mu \mathrm{L})$ ou salina no subcutâneo da bolsa escrotal. Após $2 \mathrm{~h}$ (A) ou 24h (B) da injeção do $\mathrm{VBj}$, o músculo cremaster foi exposto e os eventos celulares (rolling, adesão e migração) foram avaliados por microscopia intravital. Resultados correspondem à média \pm e.p.m. ( $\mathrm{n}=5$ animais por grupo). ${ }^{*} \mathrm{p}<0,05$ por comparação ao grupo controle (Sal+Sal). 

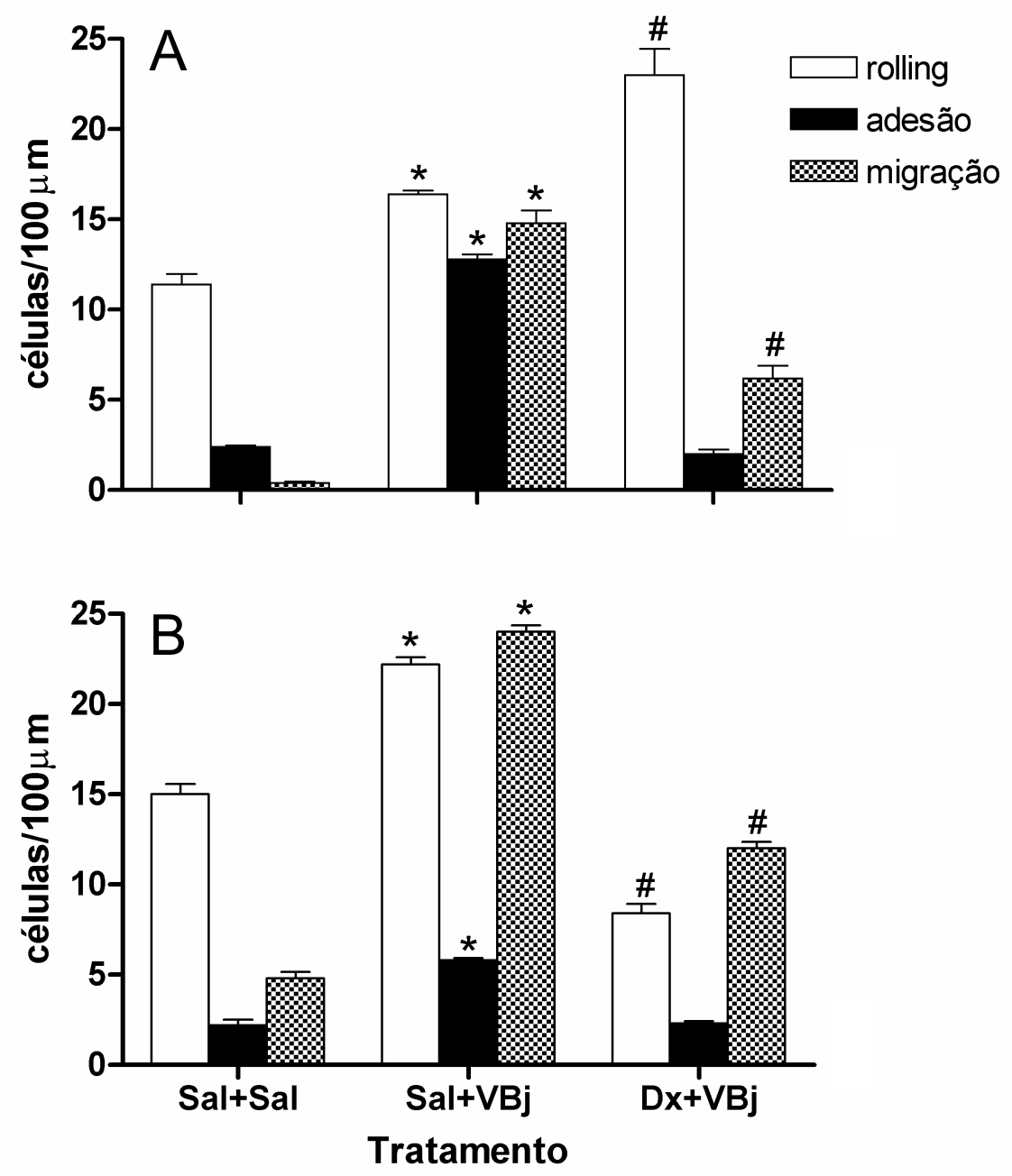

Figura 10. Efeito do pré-tratamento com dexametasona (Dx) na interação leucócito-endotélio em vênulas pós-capilares na microcirculação do músculo cremaster de camundongos induzido pelo veneno de Bothrops jararaca $(\mathrm{VBj})$.

Os animais receberam tratamento com dexametasona (Dx, $1,0 \mathrm{mg} / \mathrm{kg}$ ) ou salina (Sal), $1 \mathrm{~h}$ antes da injeção de $\operatorname{VBj}(1 \mu \mathrm{g} / 100 \mu \mathrm{L})$ ou salina no subcutâneo da bolsa escrotal. Após $2 \mathrm{~h}$ (A) ou $24 \mathrm{~h}(\mathrm{~B})$ da injeção do VBj, o músculo cremaster foi exposto e os eventos celulares (rolling, adesão e migração) foram avaliados por microscopia intravital. Resultados correspondem à média \pm e.p.m. ( $\mathrm{n}=5$ animais por grupo). ${ }^{*} \mathrm{p}<0,05$ em comparação ao grupo controle $(\mathrm{Sal}+\mathrm{Sal})$; $\# \mathrm{p}<0,05$ em comparação aos outros grupos. 


\subsubsection{Pós-tratamento com dexametasona}

Para verificar se a dexametasona reverte o efeito inflamatório induzido pelo envenenamento de $\mathrm{Bj}$, foi feito um pós-tratamento com este fármaco $1 \mathrm{~h}$ depois da injeção do VBj no subcutâneo da bolsa escrotal dos camundongos.

Após $2 \mathrm{~h}$ da injeção do veneno o grupo tratado com Dx apresentou uma significante diminuição de células em estado rolling e um aumento no tempo de $24 \mathrm{~h}$, quando comparado aos outros grupos experimentais (Figura 11).

O grupo experimental tratado com Dx apresentou uma significante diminuição de células aderidas nos dois tempos estudados, quando comparado ao grupo injetado com veneno e não apresentou diferenças estatísticas em relação ao grupo controle (Figura 11). Esta diminuição também foi observada no evento de migração celular, quando comparado ao grupo envenenado (Figura 11).

\subsubsection{Participação dos produtos originados pela via das ciclooxigenases na interação leucócito-endotélio induzida por VBj}

Para verificar a participação das enzimas ciclooxigenases (COX) nos eventos celulares da microcirculação, foi utilizado o inibidor seletivo de COX, indometacina, pré-tratando os animais 30min antes da injeção de VBj no subcutâneo da bolsa escrotal de camundongos.

Nos grupos tratados com indometacina observou-se um aumento de células em estado de rolling e uma diminuição significativa de células aderidas e migradas na $2^{\mathrm{a}}$ hora após a injeção, quando comparado ao grupo injetado com o veneno sem tratamento (Figura 12A). Na $24^{\text {a }}$ hora observou-se uma significativa diminuição nos três eventos analisados em relação aos animais injetados com veneno (Figura 12B). 

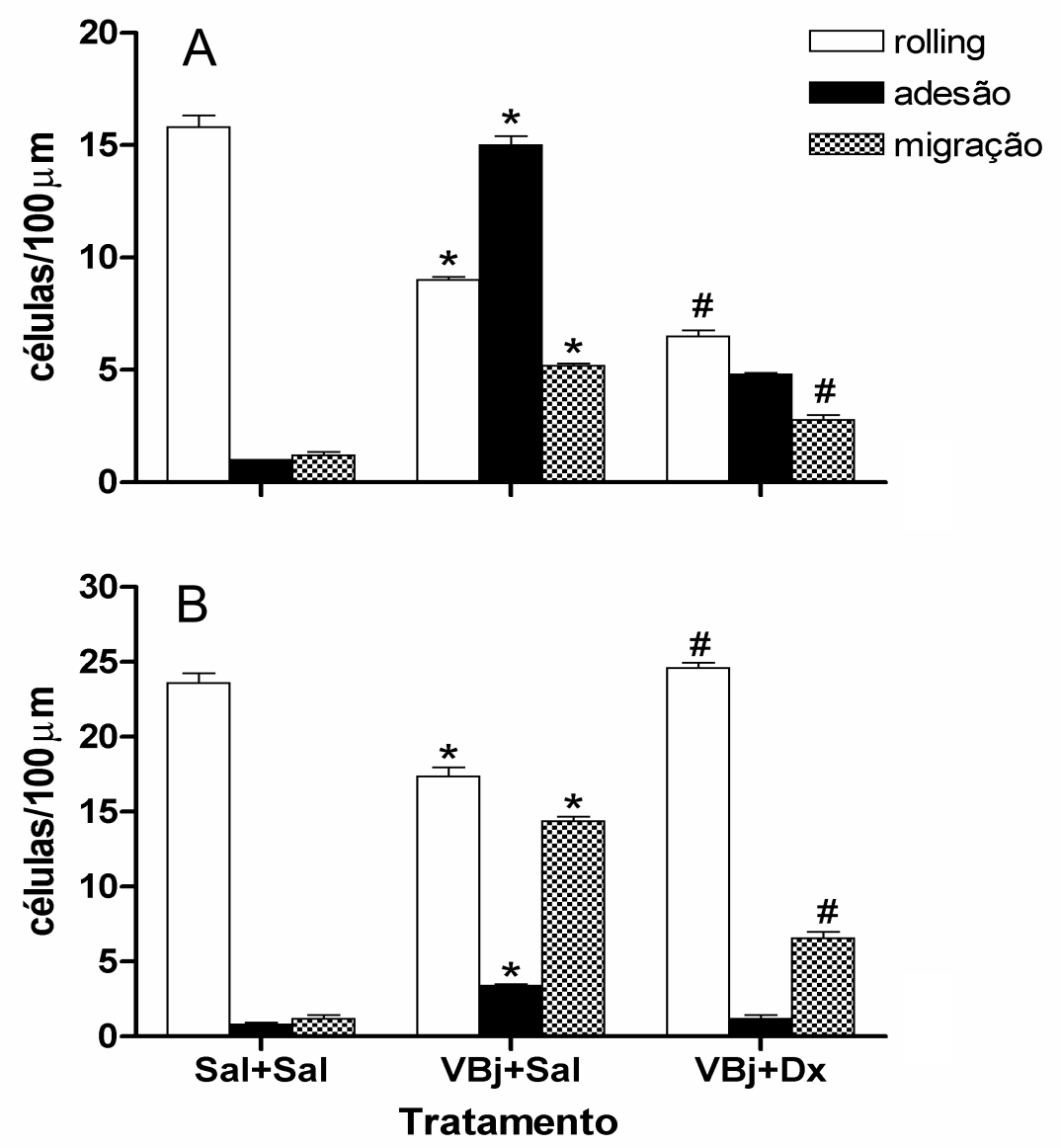

Figura 11. Efeito do pós-tratamento com dexametasona (Dx) na interação leucócito-endotélio em vênulas pós-capilares na microcirculação do músculo cremaster de camundongos induzido pelo veneno de Bothrops jararaca (VBj).

Os animais receberam tratamento com dexametasona (Dx, $1,0 \mathrm{mg} / \mathrm{kg}$ ) ou salina (Sal), $1 \mathrm{~h}$ após a injeção de $\operatorname{VBj}(1 \mu \mathrm{g} / 100 \mu \mathrm{L})$ ou salina no subcutâneo da bolsa escrotal. Após $2 \mathrm{~h}$ (A) ou $24 \mathrm{~h}$ (B) do envenenamento, o músculo cremaster foi exposto e os eventos celulares (rolling, adesão e migração) foram avaliados por microscopia intravital. Resultados correspondem à média \pm e.p.m. ( $\mathrm{n}=5$ animais por grupo). ${ }^{*} \mathrm{p}<0,05$ em comparação ao grupo controle $(\mathrm{Sal}+\mathrm{Sal})$; $\# \mathrm{p}<0,05$ em comparação aos outros grupos. 

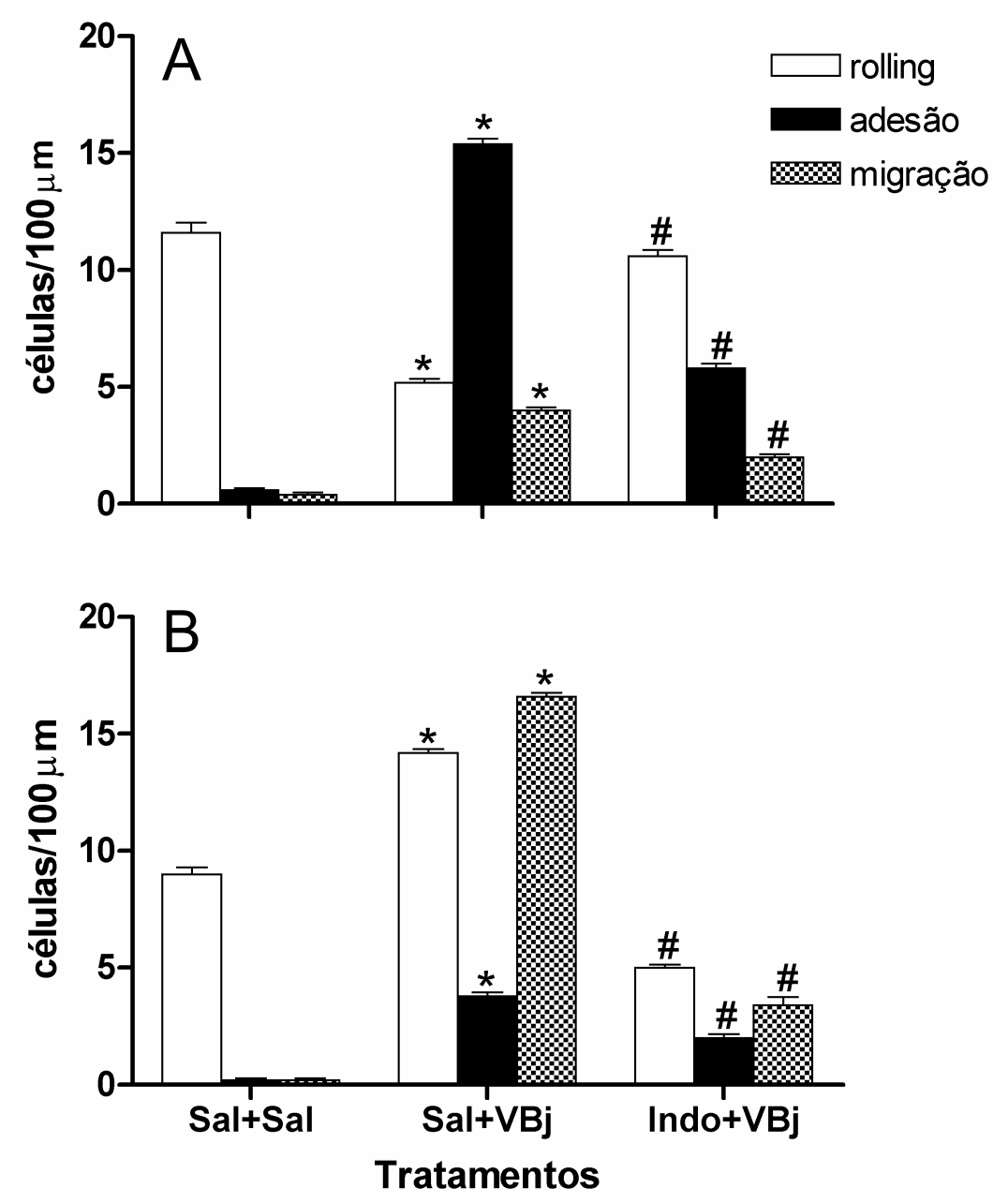

Figura 12. Efeito do pré-tratamento com indometacina (Indo) na interação leucócito-endotélio em vênulas pós-capilares na microcirculação do músculo cremaster de camundongos induzido pelo veneno de Bothrops jararaca $(\mathrm{VBj})$.

Os animais receberam tratamento com indometacina (Indo) ou salina (Sal), 30min antes da injeção de $\mathrm{VBj}(1 \mu \mathrm{g} / 100 \mu \mathrm{L})$ ou salina no subcutâneo da bolsa escrotal. Após $2 \mathrm{~h}(\mathrm{~A})$ ou 24h (B) da injeção do $\mathrm{VBj}$, o músculo cremaster foi exposto e os eventos celulares (rolling, adesão e migração) foram avaliados por microscopia intravital. Resultados correspondem à média \pm e.p.m. ( $\mathrm{n}=5$ animais por grupo). ${ }^{*} \mathrm{p}<0,05$ por comparação ao grupo controle $(\mathrm{Sal}+\mathrm{Sal})$. $\# \mathrm{p}<0,05$ em comparação ao grupo controle e ao grupo injetado com VBj. 


\subsubsection{Participação dos produtos originados pela via da ciclooxigenase-2 na interação leucócito-endotélio induzido por VBj}

Para analisar a possível participação dos produtos originados pela via ciclooxigenase-2 (COX-2) nos eventos celulares da microcirculação, foi feito com o pré-tratamento com o inibidor seletivo celecoxib, 30min antes da injeção de VBj no subcutâneo da bolsa escrotal de camundongos.

O celecoxib mostrou-se eficiente em aumentar o número de células em rolling e inibir os leucócitos aderidos na $2^{\mathrm{a}}$ hora após a injeção do veneno, quando comparado ao grupo injetado com o veneno sem tratamento (Figura 13A). Entretanto, o celecoxibe inibiu o rolling leucocitário na $24^{\mathrm{a}}$ hora após da injeção do veneno e inibiu os eventos de adesão e migração após $24 \mathrm{~h}$ do tratamento com o $\mathrm{VBj}$, apresentando diferenças significantes, principalmente em relação ao evento de migração celular (Figura 13B).

\subsubsection{Participação dos produtos originados pela via da lipoxigenase na interação leucócito-endotélio induzida por VBj}

A verificação da participação da lipoxigenase foi observada com o pré-tratamento com o inibidor ácido nordiidroguaiarético (NDGA), 30min antes da injeção de VBj no subcutâneo da bolsa escrotal de camundongos.

Não foi observado efeito inibitório das alterações da interação leucócito-endotélio nos animais tratados com NDGA (Figura 14). O número de células aderidas não diferiu estatisticamente dos animais injetado com veneno sem tratamento, nos dois tempos analisados. Em relação ao evento de rolling celular, o pré-tratamento com NDGA induziu um discreto aumento no tempo de $2 \mathrm{~h}$ e uma diminuição bastante considerável no tempo de $24 \mathrm{~h}$, com relação ao grupo injetado com veneno não tratado (Figura 14). Ainda, o grupo tratado com NDGA antes da injeção de $\mathrm{VBj}$ aumentou o número de células migradas após $2 \mathrm{~h}$ da injeção, quando comparado com o grupo controle como com o grupo de animais injetados com veneno sem tratamento (Figura 14). 

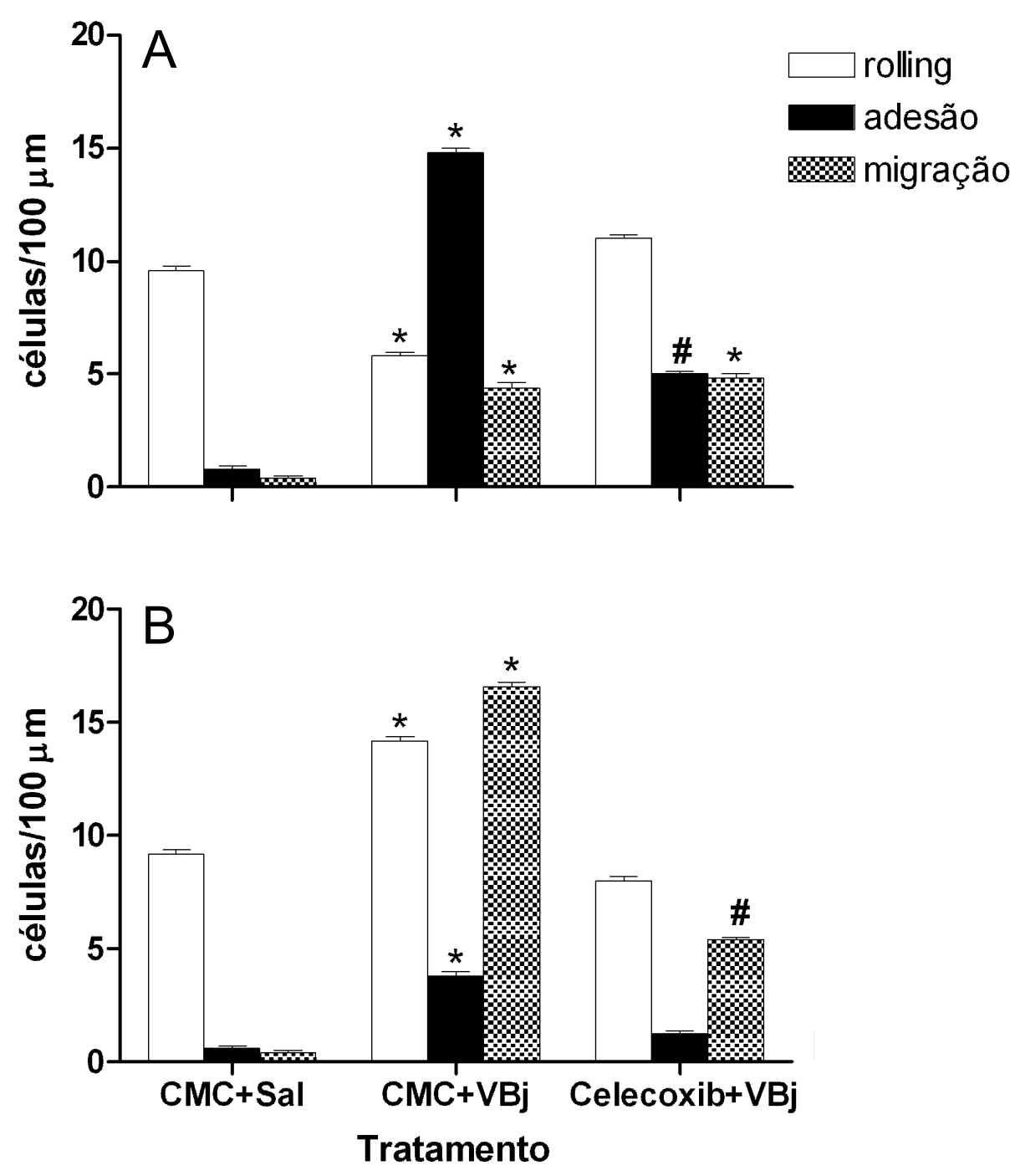

Figura 13. Efeito do pré-tratamento com celecoxib interação leucócito-endotélio em vênulas póscapilares na microcirculação do músculo cremaster de camundongos induzido pelo veneno de Bothrops jararaca $(\mathrm{VBj})$.

Os animais receberam tratamento com celecoxibe ou carboximetil (CMC), 30min antes da injeção de VBj $(1 \mu \mathrm{g} / 100 \mu \mathrm{L})$ ou salina (Sal) no subcutâneo da bolsa escrotal. Após 2h (A) ou 24h (B) da injeção do VBj, o músculo cremaster foi exposto e os eventos celulares (rolling, adesão e migração) foram avaliados por microscopia intravital. Resultados correspondem à média \pm e.p.m. ( $\mathrm{n}=5$ animais por grupo). ${ }^{*} \mathrm{p}<0,05$ por comparação ao grupo controle $(\mathrm{Sal}+\mathrm{Sal})$. $\# \mathrm{p}<0,05$ em comparação ao grupo controle e ao grupo injetado com VBj. 

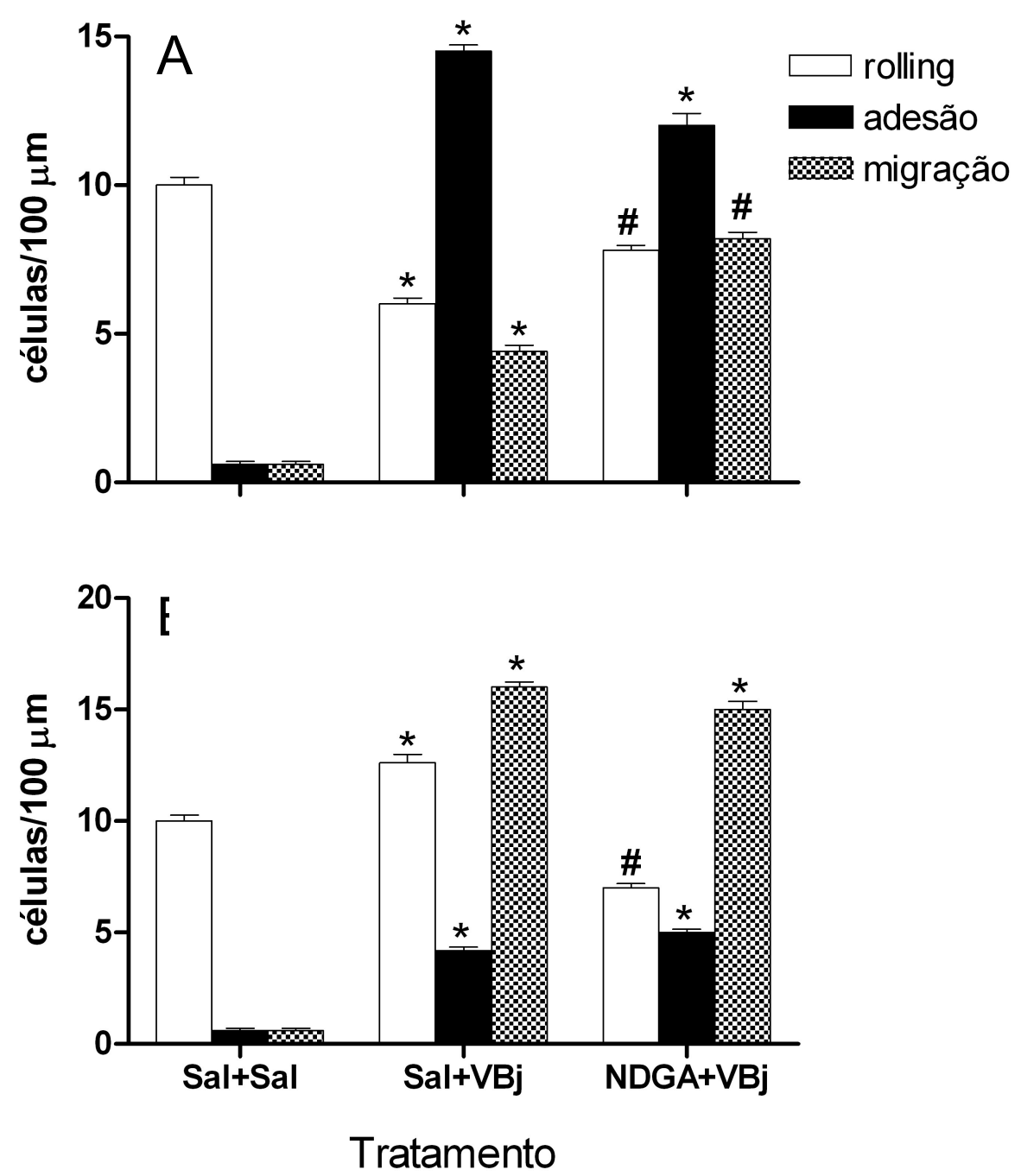

Figura 14. Efeito do pré-tratamento com ácido nordiidroguaiarético (NDGA) na interação leucócito-endotélio em vênulas pós-capilares na microcirculação do músculo cremaster de camundongos induzido pelo veneno de Bothrops jararaca (VBj).

Os animais receberam tratamento com ácido nordiidroguaiarético (NDGA) ou salina (Sal), 30min antes da injeção de $\operatorname{VBj}(1 \mu \mathrm{g} / 100 \mu \mathrm{L})$ ou salina no subcutâneo da bolsa escrotal. Após 2h (A) ou 24h (B) da injeção do VBj, o músculo cremaster foi exposto e os eventos celulares (rolling, adesão e migração) foram avaliados por microscopia intravital. Resultados correspondem à média \pm e.p.m. ( $\mathrm{n}=5$ animais por grupo). ${ }^{*} \mathrm{p}<0,05$ por comparação ao grupo controle $(\mathrm{Sal}+\mathrm{Sal})$. \#p $<0,05$ em comparação ao grupo controle e ao grupo injetado com VBj. 


\subsubsection{Participação do fator de necrose tumoral-a na interação leucócito-endotélio induzido por $\mathrm{VBj}$}

Foi feito um pré-tratamento com pentoxifilina, um inibidor específico do fator de necrose tumoral- $\alpha$ (TNF- $\alpha)$, 30min antes da injeção de VBj no subcutâneo da bolsa escrotal de camundongos para verificar sua participação neste envenenamento.

Nos grupos tratados com pentoxifilina observou-se uma diminuição significativa de células aderidas na $2^{\mathrm{a}}$ hora após a injeção do veneno, quando comparado ao grupo injetado com o veneno (Figura 15A), no entanto, não houve diferenças estatísticas em relação ao evento de rolling e migração celular. $\mathrm{Na} 24^{\mathrm{a}}$ hora observou-se uma significativa diminuição nos eventos celulares de rolling, adesão e migração em relação ao grupo injetado com veneno (Figura 15B).

\subsubsection{Participação do óxido nítrico sintase na interação leucócito-endotélio induzido por VBj}

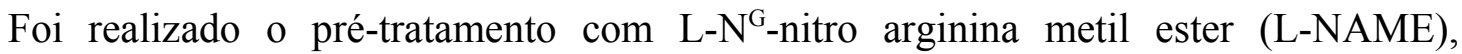
inibidor inespecífico do óxido nítrico sintase (NOS), 30mim da injeção de VBj no subcutâneo da bolsa escrotal de camundongos para verificar sua participação nestas alterações.

O pré-tratamento dos animais com L-NAME induziu uma significativa diminuição do número de células aderidas e migradas na $2^{\mathrm{a}}$ hora após a injeção do veneno, quando comparado ao grupo injetado com o veneno não tratado (Figura 16A). Ainda, o L-NAME foi capaz de inibir todos os eventos de interação leucócito-endotélio avaliados na $24^{a}$ hora após a injeção do veneno, também quando comparado ao grupo injetado com o veneno não tratado (Figura 16B). 

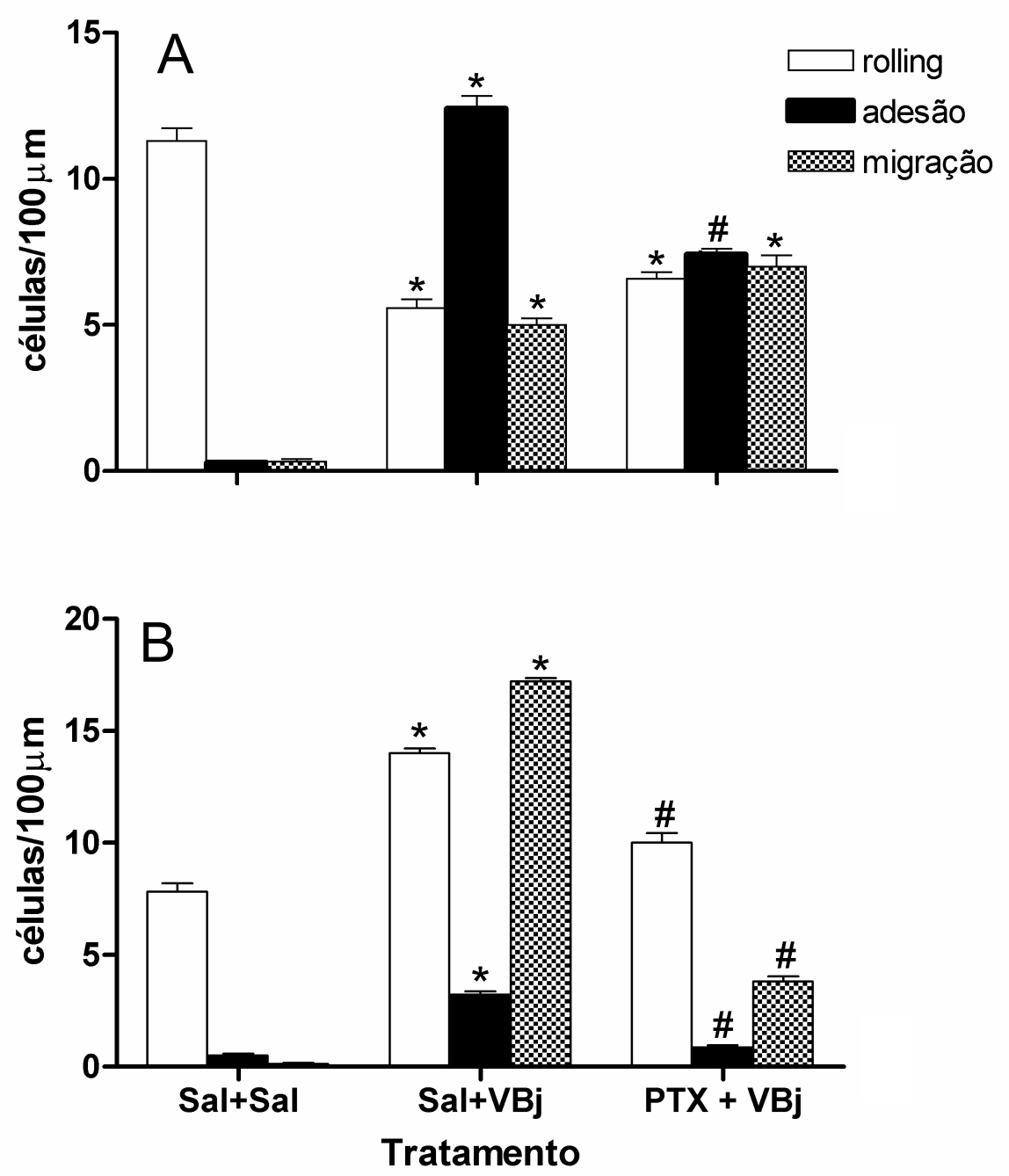

Figura 15. Efeito do pré-tratamento com pentoxifilina (PTX) na interação leucócito-endotélio em vênulas pós-capilares na microcirculação do músculo cremaster de camundongos induzido pelo veneno de Bothrops jararaca (VBj).

Os animais receberam tratamento com pentoxifilina (PTX) ou salina (Sal), 30min antes da injeção de $\mathrm{VBj}(1 \mu \mathrm{g} / 100 \mu \mathrm{L})$ ou salina no subcutâneo da bolsa escrotal. Após $2 \mathrm{~h}(\mathrm{~A})$ ou 24h (B) da injeção do $\mathrm{VBj}$, o músculo cremaster foi exposto e os eventos celulares (rolling, adesão e migração) foram avaliados por microscopia intravital. Resultados correspondem à média \pm e.p.m. ( $\mathrm{n}=5$ animais por grupo). ${ }^{*} \mathrm{p}<0,05$ por comparação ao grupo controle $(\mathrm{Sal}+\mathrm{Sal})$. $\# \mathrm{p}<0,05$ em comparação ao grupo controle e ao grupo injetado com VBj. 

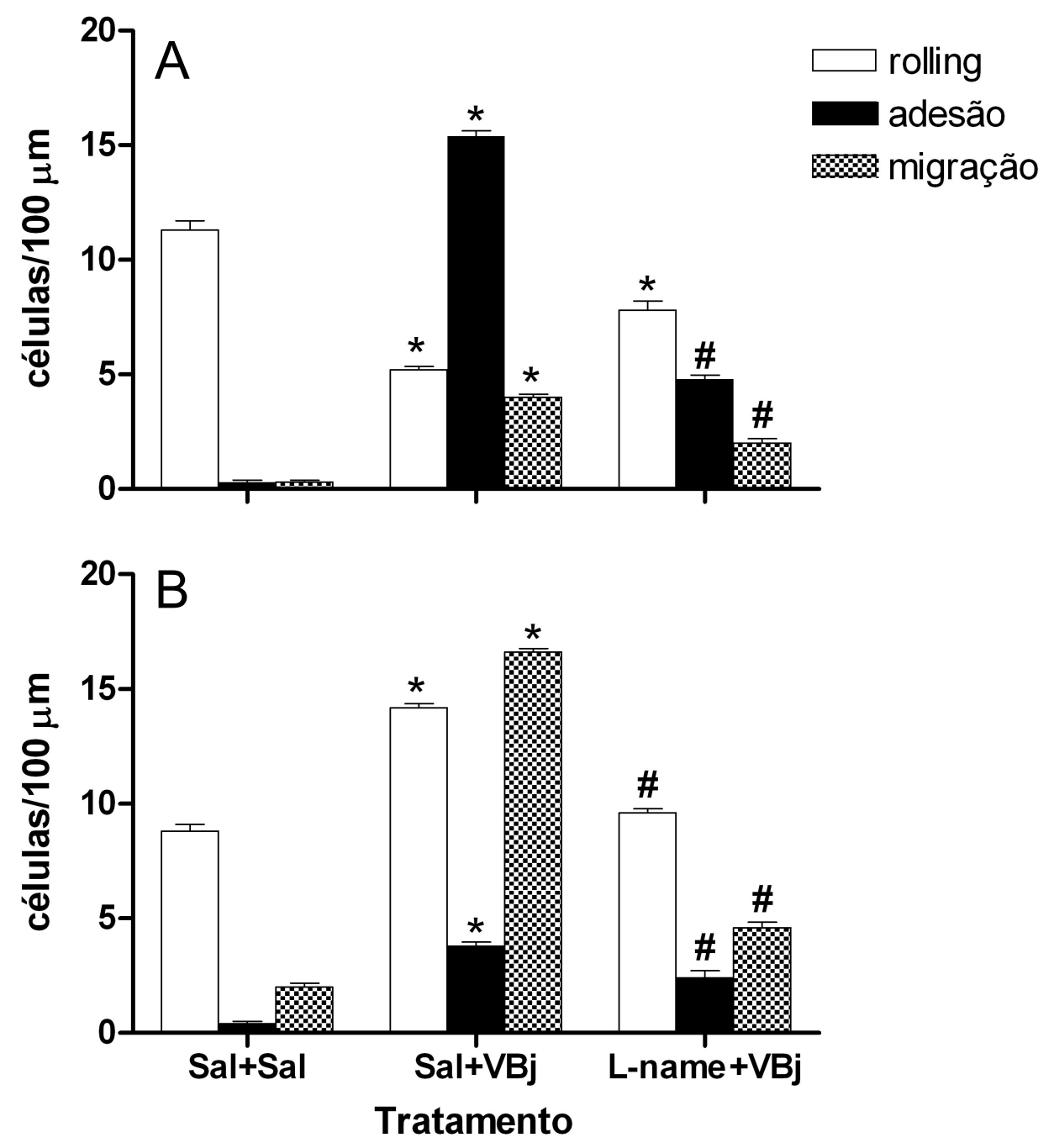

Figura 16. Efeito do pré-tratamento com $L-N^{G}$-nitro arginina metil ester (L-NAME) na interação leucócito-endotélio em vênulas pós-capilares na microcirculação do músculo cremaster de camundongos induzido pelo veneno de Bothrops jararaca (VBj).

Os animais receberam tratamento com L-NAME ou salina (Sal), 30min antes da injeção de $\operatorname{VBj}(1 \mu \mathrm{g} / 100 \mu \mathrm{L})$ ou salina no subcutâneo da bolsa escrotal. Após $2 \mathrm{~h}(\mathrm{~A})$ ou $24 \mathrm{~h}$ (B) da injeção do $\mathrm{VBj}$, o músculo cremaster foi exposto e os eventos celulares (rolling, adesão e migração) foram avaliados por microscopia intravital. Resultados correspondem à média \pm e.p.m. ( $\mathrm{n}=5$ animais por grupo). ${ }^{*} \mathrm{p}<0,05$ por comparação ao grupo controle $(\mathrm{Sal}+\mathrm{Sal})$. $\# \mathrm{p}<0,05$ em comparação ao grupo controle e ao grupo injetado com VBj. 


\subsubsection{Participação do óxido nítrico sintase indizível na interação leucócito-endotélio induzido por $\mathrm{VBj}$}

Foi feito pré-tratamento com aminoguanidina, inibidor seletivo do óxido nítrico sintase indizível (iNOS), 30mim da injeção de VBj no subcutâneo da bolsa escrotal de camundongos para verificar sua participação nestas alterações.

Duas horas após a injeção do $\mathrm{VBj}$, o pré-tratamento com aminoguanidina induziu uma diminuição significante em relação ao evento de adesão e migração celular, quando comparado ao grupo de veneno sem tratamento (Figura 17A). O número de rolling não mostrou diferença estatística do grupo controle, porém houve um aumento com relação ao grupo com veneno não tratado (Figura 17A). Em relação ao tempo de $24 \mathrm{~h}$ houve uma grande diminuição de células migradas, quando comparado ao grupo injetado com veneno, e os eventos de rolling e adesão não se mostraram diferentes do grupo controle (Figura 17B).

Os resultados obtidos com diversos tratamentos farmacológicos estão apresentados, de forma resumida, na Tabela 2. Cabe ressaltar que todos os fármacos utilizados per se não causaram alterações significativas dos padrões de interação leucócito-endotélio (dados não mostrados). 

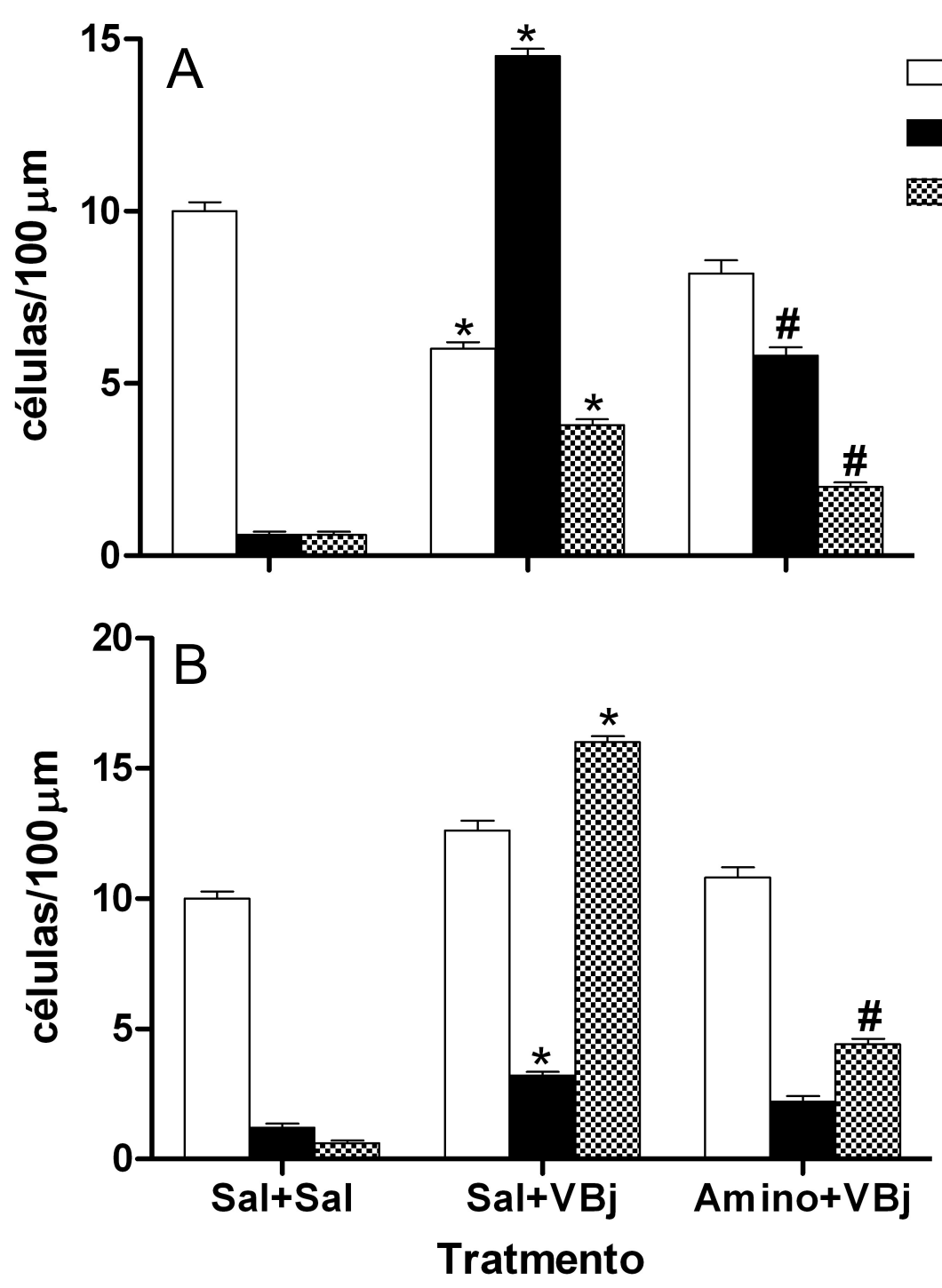

Figura 17. Efeito do pré-tratamento com Aminoguanidina (Amino) na interação leucócitoendotélio em vênulas pós-capilares na microcirculação do músculo cremaster de camundongos induzido pelo veneno de Bothrops jararaca (VBj).

Os animais receberam tratamento com Aminoguanidina (Amino) ou salina (Sal), 30min antes da injeção de $\operatorname{VBj}(1 \mu \mathrm{g} / 100 \mu \mathrm{L})$ ou salina (Sal) no subcutâneo da bolsa escrotal. Após 2h (A) ou 24h (B) da injeção do VBj, o músculo cremaster foi exposto e os eventos celulares (rolling, adesão e migração) foram avaliados por microscopia intravital. Resultados correspondem à média \pm e.p.m. ( $\mathrm{n}=5$ animais por grupo). ${ }^{*} \mathrm{p}<0,05$ por comparação ao grupo controle $(\mathrm{Sal}+\mathrm{Sal})$. $\# \mathrm{p}<0,05$ em comparação ao grupo controle e ao grupo injetado com $\mathrm{VBj}$. 
Tabela 2. Quadro de resumo dos efeitos dos diversos tratamentos farmacológicos sobre os eventos celulares da interação leucócito-endotélio no músculo cremaster de camundongos induzidos por $\mathrm{VBj}$.

\begin{tabular}{|c|c|c|c|c|c|c|}
\hline \multirow[t]{2}{*}{ Fármacos } & \multicolumn{2}{|c|}{ rolling } & \multicolumn{2}{|c|}{ adesão } & \multicolumn{2}{|c|}{ migração } \\
\hline & $2 \mathrm{~h}$ & $24 \mathrm{~h}$ & $2 \mathrm{~h}$ & $24 \mathrm{~h}$ & $2 \mathrm{~h}$ & $24 \mathrm{~h}$ \\
\hline Prometazina & $>$ & - & - & - & - & - \\
\hline Metissergida & $>$ & $<$ & - & - & - & - \\
\hline Dexametasona (pré) & $>>$ & $<<$ & $<<$ & $<<$ & $<<$ & $<<$ \\
\hline Dexametasona (pós) & $<<$ & $>>$ & $<<$ & $<<$ & $<<$ & $<<$ \\
\hline Indometacina & $>>$ & $<<$ & $<<$ & $<$ & $<$ & $<<$ \\
\hline Celecoxib & $>>$ & $<<$ & $<<$ & $<$ & - & $<<$ \\
\hline NDGA & $>$ & $<$ & - & - & $>$ & - \\
\hline Pentoxifelina & - & $<$ & $<<$ & $<$ & - & $<<$ \\
\hline L-NAME & - & $<$ & $<<$ & $<$ & $<$ & $<<$ \\
\hline Aminoguanidina & $>$ & - & $<<$ & $<$ & $<$ & $<<$ \\
\hline \multicolumn{7}{|l|}{ — sem efeito } \\
\hline \multicolumn{7}{|l|}{$>$ aumento } \\
\hline \multicolumn{7}{|l|}{ >> aumento acentuado } \\
\hline \multicolumn{7}{|l|}{$<$ diminuição } \\
\hline$<<$ diminuição acentua & & & & & & \\
\hline
\end{tabular}




\subsection{Soroneutralização}

\subsubsection{Interação leucócito-endotélio induzida por VBj em animais pré-tratados com soro antibotrópico}

Para observar a eficiência do antiveneno em inibir as alterações da interação leucócito-endotélio causadas pelo $\mathrm{VBj}$, foi feito o pré-tratamento com soro antibotrópico (SAB), 30min da injeção de VBj no subcutâneo da bolsa escrotal de camundongos.

Os grupos pré-tratados com SAB apresentaram uma diminuição significativa no número de células em rolling, quando comparados com o grupo controle, injetado apenas com salina, no tempo de $2 \mathrm{~h}$ (Figura. 18A). No tempo de $24 \mathrm{~h}$ os grupos não diferiram entre si, apenas o grupo tratado com $\mathrm{SAB}+\mathrm{VBj}$ apresentou um grande aumento de células (Figura 18B).

Em relação à adesão leucocitária, nos dois tempos observados os grupos tratados com $\mathrm{SAB}$, com $\mathrm{VBj}$ sem tratamento ou com $\mathrm{SAB}+\mathrm{VBj}$ apresentaram um aumento de células aderidas, quando comparado com o grupo salina, sendo bastante acentuado o aumento no tempo de $2 \mathrm{~h}$ quando comparados ao grupo salina (Figura 18). Houve um expressivo aumento de migração tanto no grupo submetidos ao tratamento com $\mathrm{SAB}$, quanto no grupo injetado de VBj sem tratamento, nos dois tempos estudados, quando comparados ao controle. Sendo este aumento mais expressivo no tempo de 24h (Figura 18). 

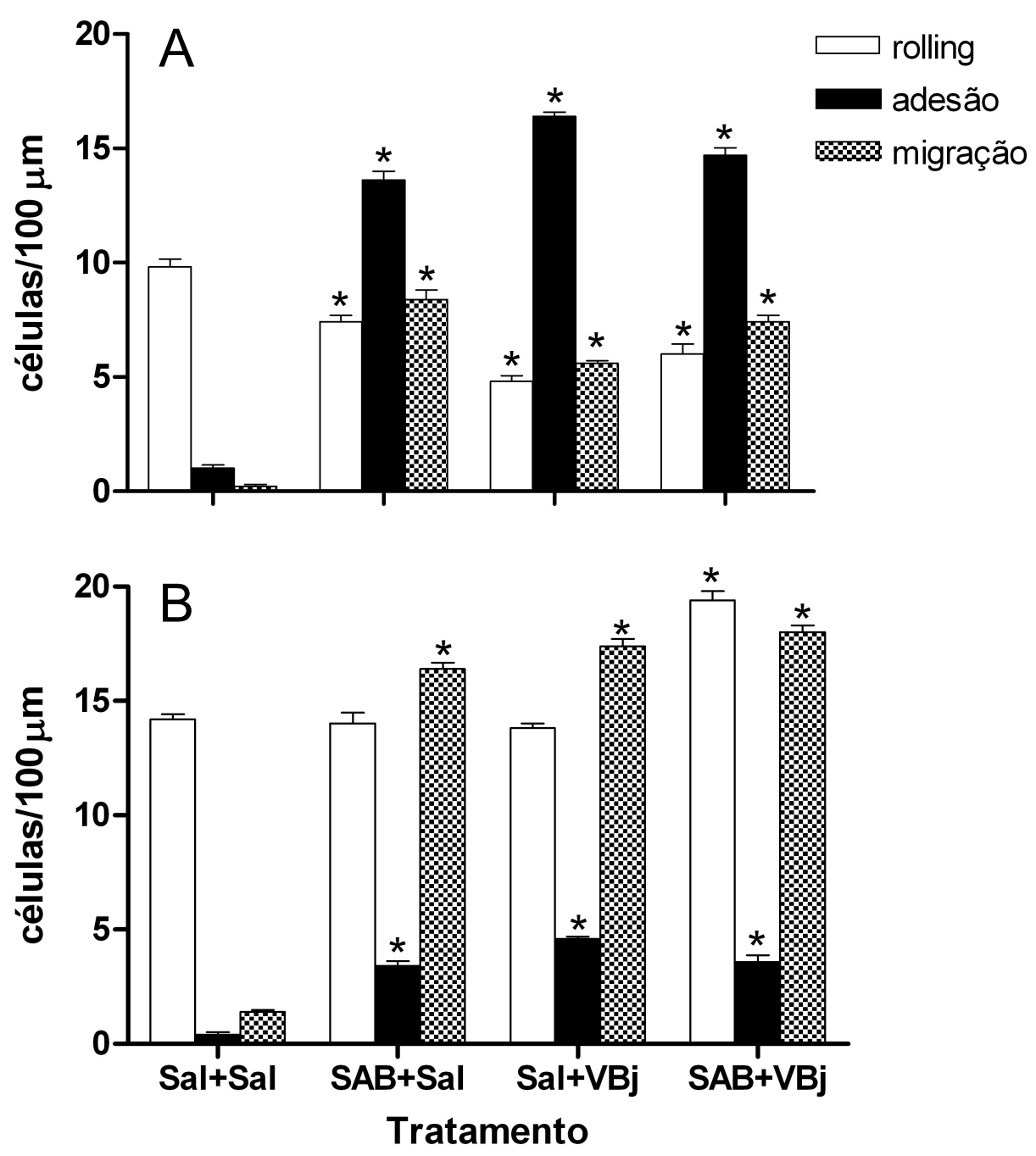

Figura 18. Efeito do pré-tratamento com soro antibotrópico na interação leucócito-endotélio induzido pelo veneno de Bothrops jararaca (VBj) em vênulas pós-capilares na microcirculação do músculo cremaster de camundongos.

Os animais receberam tratamento com soro antibotrópico (SAB, $200 \mu \mathrm{L}$, i.v.) ou salina (Sal), 30min antes da injeção de $\mathrm{VBj}(1 \mu \mathrm{g} / 100 \mu \mathrm{L})$ ou salina no subcutâneo da bolsa escrotal. Após 2h (A) ou 24h(B) da injeção do VBj, o músculo cremaster foi exposto e os eventos celulares (rolling, adesão e migração) foram avaliados por microscopia intravital. Resultados correspondem à média \pm e.p.m. ( $n=5$ animais por grupo). ${ }^{*} \mathrm{p}<0,05 \mathrm{em}$ comparação ao grupo controle (Sal+Sal). 


\subsubsection{Interação leucócito-endotélio induzida por SAB, fenol e SAB sem fenol}

Uma vez que o SAB endovenoso, per se, induziu o aumento de células aderidas e migradas semelhante ao observado nos animais injetados somente com $\mathrm{VBj}$, procurou-se verificar qual componente deste soro estaria causando esse efeito. O SAB é constituído de fração $\mathrm{F}(\mathrm{ab})_{2}$ de $\mathrm{IgG}$ e contém $0.25 \%$ de fenol, utilizado como conservante (referencia). Assim, verificou-se o efeito da injeção i.v. se uma solução de SAB sem fenol e de uma solução de fenol, na mesma concentração encontrada no SAB, comparando-se aos resultados obtidos com a injeção i.v.de SAB com fenol.

O SAB (com fenol) ou o fenol quando administrados i.v. em camundongos provocaram reações de tremores e dispnéia (Tabela 3), estas reações foram amenizadas conforme a diminuição da dose administrada ou quando injetada diluída com solução salina, e não foram observadas após a injeção do soro sem o fenol.

Após $2 \mathrm{~h}$ da injeção foi observado que o grupo injetado com fenol teve um aumento significativo no número de leucócitos em rolling e adesão em relação ao grupo injetado com salina, tal como observado no grupo injetado com SAB (com fenol) (Figura 19). Já o grupo injetado com SAB sem fenol apresentou uma diminuição de células em rolling e um aumento discreto de células aderidas quando comparado com o grupo injetado com salina, porém este aumento foi significativamente menor em relação aos outros grupos injetados com SAB ou fenol (Figura 19). 
Tabela 3. Tempo de tremores e dispnéia imediatamente após a administração i.v. de diferentes doses do soro antibotrópico com fenol.

\begin{tabular}{lc}
\hline \multicolumn{1}{c}{ SAB (i.v.) } & Tempo de tremor/dispnéia \\
\hline $200 \mu \mathrm{L}$ & $123,5 \mathrm{seg}$. \\
$100 \mu \mathrm{L}$ & $53 \mathrm{seg}$ \\
$50 \mu \mathrm{L}$ & $7,3 \mathrm{seg}$ \\
$100 \mu \mathrm{L}(\mathrm{SAB})+100 \mu \mathrm{L}(\mathrm{Sal})$ & $11,25 \mathrm{seg}$ \\
$200 \mu \mathrm{L} \mathrm{SAB} \mathrm{sem} \mathrm{fenol}$ & --- \\
\hline
\end{tabular}

SAB - soro antibotrópico

Sal - salina 


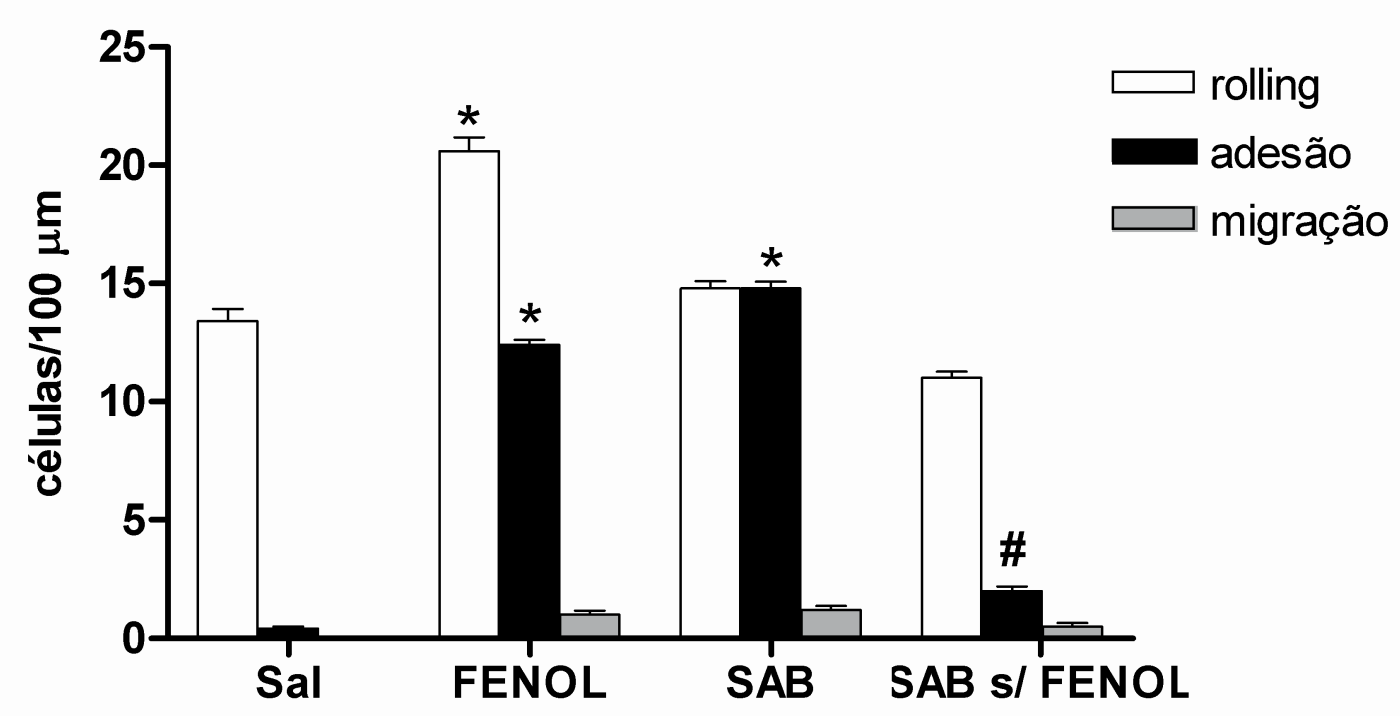

Figura 19. Interação leucócito-endotélio em vênulas pós-capilares na microcirculação do músculo cremaster de camundongos induzida por fenol, soro antibotrópico ou soro antibotrópico sem fenol.

Os animais receberam a injeção de $200 \mu \mathrm{L}$ i.v. de fenol, soro antibotrópico (SAB), SAB sem fenol ou salina (Sal). Após $2 \mathrm{~h}$, o músculo cremaster foi exposto e os eventos celulares (rolling, adesão e migração) foram avaliados por microscopia intravital. Resultados correspondem à média \pm e.p.m. ( $\mathrm{n}=5$ animais por grupo). ${ }^{*} \mathrm{p}<0,05$ por comparação ao grupo salina; $\# \mathrm{p}<0.05$ em comparação aos outros grupos. 


\subsubsection{Participação da histamina na reação induzida pelo SAB ou fenol}

Quando injetado i.v., tanto o SAB como a solução de fenol provocaram fortes tremores e dispnéia nos animais. Efeitos, estes, que se revertem espontaneamente e não são observados no grupo injetado com o SAB sem fenol.

Ao se verificarem esses tremores e dispnéia analisou-se se este efeito seria devido a uma reação anafilática do tipo I dependente da histamina, uma vez que é determinada a participação desta amina vasoativa em situações semelhantes (Fan et al., 1999). Assim foi feito um pré-tratamento com prometazina, 30min antes da injeção de SAB ou fenol, sem a injeção de VBj ou salina na bolsa escrotal dos animais.

Observamos que o tratamento com prometazina não alterou o padrão de rolling e adesão, dos grupos injetados com SAB ou fenol (Figura 20).

\subsubsection{Soroneutralização pelo SAB sem fenol}

\subsubsection{Pré-tratamento de SAB sem fenol}

Para verificar se o SAB sem fenol possui anticorpos capazes de neutralizar o VBj, foi feito o tratamento com SAB sem fenol $1 \mathrm{~h}$ antes da injeção de VBj no subcutâneo da bolsa escrotal dos animais.

O SAB sem fenol, per se, mostrou-se eficaz em inibir os eventos de rolling, adesão e migração celular em vênulas pós-capilares após a injeção de VBj (Figura 21). O prétratamento com $\mathrm{SAB}$ sem fenol, antes do $\mathrm{VBj}$, não induziu diferença no rolling leucocitário, nos dois tempos avaliados, com relação ao grupo tratado com Sal+VBj (Figura 21). No tempo de $2 \mathrm{~h}$ após, o grupo pré-tratado com o SAB sem fenol apresentou uma diminuição significativa do número de células aderidas, quando comparado ao grupo injetado somente com o VBj (Figura 21A), esta diminuição não foi estatisticamente diferente no tempo de $24 \mathrm{~h}$ (Figura 21B). Em relação ao evento de migração celular o grupo de SAB sem fenol apresentou uma diminuição significativa, nos dois tempos analisados, quando comparado ao grupo injetado somente com o VBj (Figura 21). 


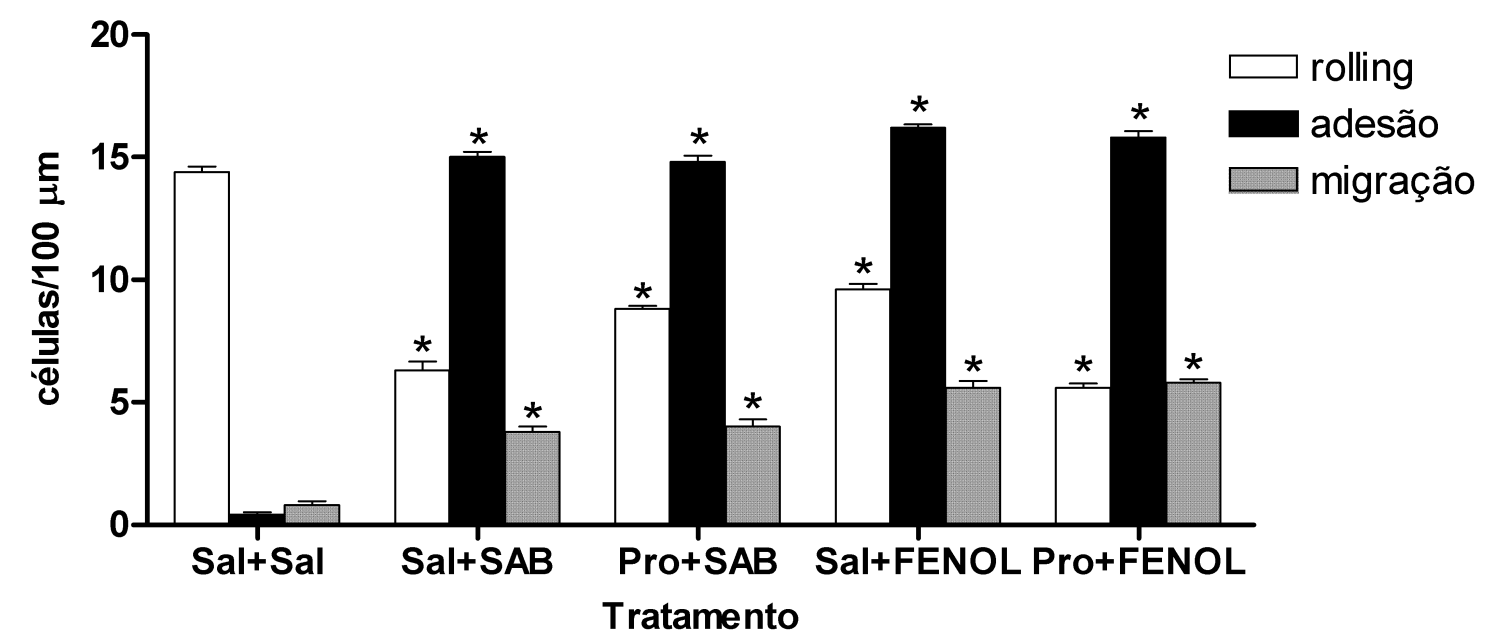

Figura 20. Efeito do pré-tratamento de prometazina na interação leucócito-endotélio em vênulas pós-capilares na microcirculação do músculo cremaster de camundongos induzida pelo soro antibotrópico ou fenol.

Os animais receberam tratamento com prometazina (Pro, $10 \mathrm{mg} / \mathrm{kg}$ i.p.) $30 \mathrm{~min}$ antes da injeção $200 \mu \mathrm{L}$ i.v. de soro antibotrópico (SAB), fenol ou salina (Sal). Após $2 \mathrm{~h}$ da injeção do SAB ou fenol, o músculo cremaster foi exposto e os eventos celulares (rolling, adesão e migração) foram avaliados por microscopia intravital. Resultados correspondem à média \pm e.p.m. ( $n=5$ animais por grupo). ${ }^{*} \mathrm{p}<0,05$ por comparação ao grupo controle (Sal+Sal); $\# \mathrm{p}<0.05$ em comparação aos outros grupos. 

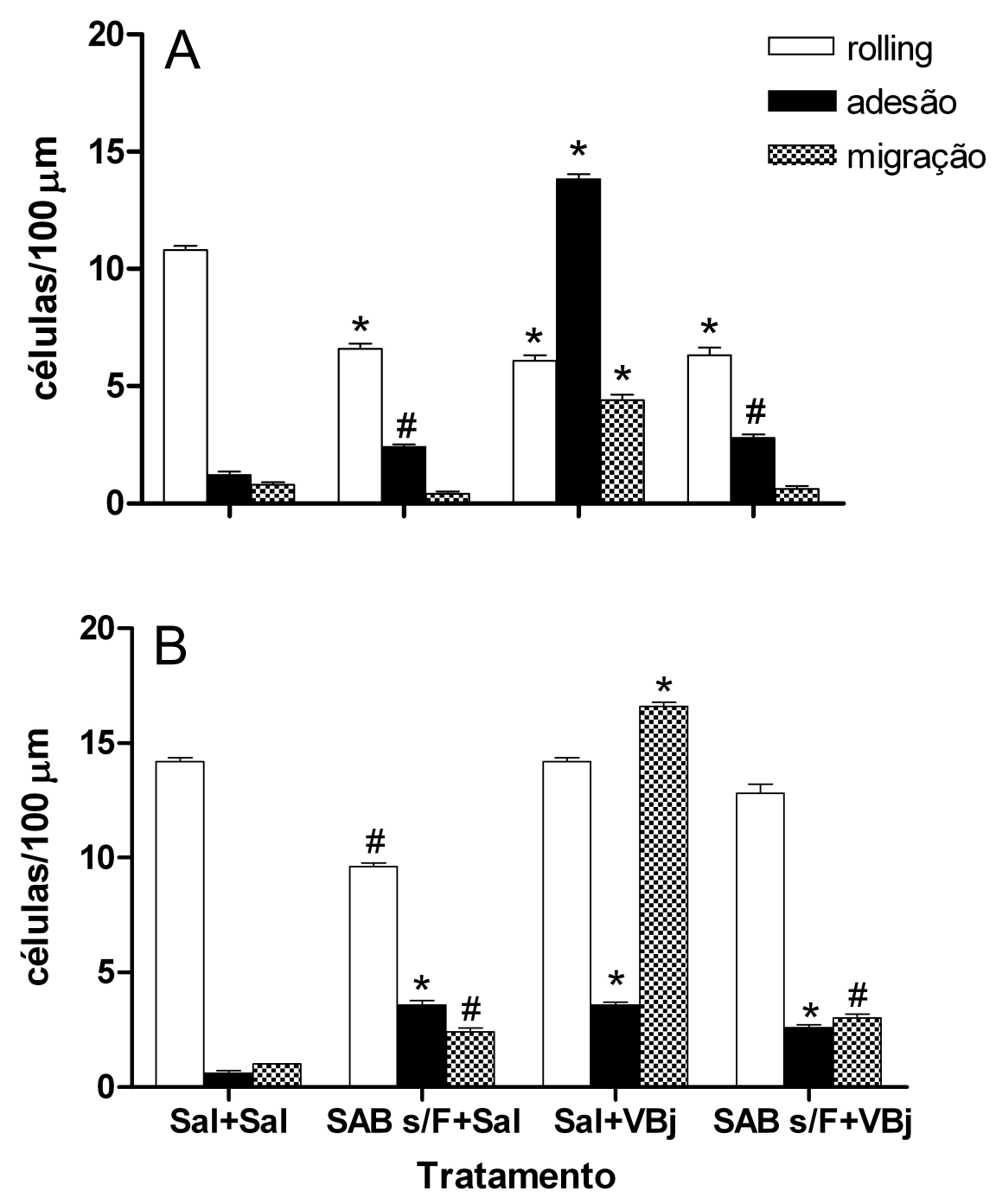

Figura 21. Efeito do pré-tratamento com soro antibotrópico sem fenol na interação leucócitoendotélio em vênulas pós-capilares na microcirculação do músculo cremaster de camundongos induzido pelo veneno de Bothrops jararaca (VBj).

Os animais receberam tratamento com soro antibotrópico (SAB) sem fenol (SAB s/F, 200 $\mu \mathrm{L}$ i.v.) ou salina (Sal), $1 \mathrm{~h}$ antes da injeção de $\mathrm{VBj}(1 \mu \mathrm{g} / 100 \mu \mathrm{L})$ ou salina no subcutâneo da bolsa escrotal. Após $2 \mathrm{~h}$ (A) ou $24 \mathrm{~h}$ (B) da injeção do $\mathrm{VBj}$, o músculo cremaster foi exposto e os eventos celulares (rolling, adesão e migração) foram avaliados por microscopia intravital. Resultados correspondem à média \pm e.p.m. $(\mathrm{n}=5$ animais por grupo). ${ }^{*} \mathrm{p}<0,05$ por comparação ao grupo controle (Sal+Sal); \#p $<0.05$ em comparação aos outros grupos. 


\subsubsection{Pós-tratamento de SAB sem fenol}

Foi também realizado o pós-tratamento com SAB sem fenol 1h após a injeção de VBj no subcutâneo da bolsa escrotal dos animais e os eventos celulares foram analisados.

O SAB sem fenol, per se, mostrou-se também eficaz em reverter os eventos de rolling, adesão e migração celular em vênulas pós-capilares, após $2 \mathrm{~h}$ do seu tratamento (Figura 22). O pós-tratamento com SAB sem fenol induziu uma significativa diminuição de células aderidas e migradas em 2 e 24 h após a injeção de $\mathrm{VBj}$, quando comparado ao grupo injetado somente com veneno (Figura 22). Em relação ao parâmetro de rolling, o grupo tratado com SAB sem fenol não apresentou diferença estatística em relação ao grupo tratado somente com veneno na $2^{\mathrm{a}}$ hora analisada (Figura 22A), porém no tempo de $24 \mathrm{~h}$ apresentou uma diminuição de células em rolling com relação ao grupo tratado somente com veneno, mas não diferiu do grupo controle (Figura 22B).

\subsection{Associação farmacológica de dexametasona com SAB com fenol}

Os grupos analisados após $2 \mathrm{~h}$ da injeção do veneno não apresentaram diferença estatística no rolling celular, apenas o grupo injetado com salina na bolsa escrotal e tratado com a associação de dexametasona (Dx) e SAB apresentou uma diminuição discreta, porém diferente estatisticamente quando comparado com o controle (Figura 23A). Na adesão leucocitária os grupos tratados com Dx associado ao SAB não apresentaram diferenças com o grupo controle. Já os grupos envenenados com ou sem tratamento do SAB apresentaram um aumento exorbitante de adesão celular (Figura 23A). O mesmo foi observado no evento de migração celular, onde o grupo envenenado tratado com o SAB teve um aumento bastante significativo em relação ao controle e até mesmo ao grupo VBj sem tratamento (Figura 23A).

Após $24 \mathrm{~h}$ da injeção de VBj ou salina na bolsa escrotal dos animais foi observada uma diminuição de rolling nos grupos tratados com a associação de Dx e SAB, em relação ao grupo controle e aos tratados com SAB (Figura 23B). No evento de adesão todos os grupos apresentaram um pequeno aumento, porém significativo estatisticamente, em relação ao controle (Figura 23B). Na migração celular também foi observado um aumento de células em todos os grupos analisados quando comparados ao controle, porém este aumento foi mais intenso nos grupos $\mathrm{VBj}$ sem nenhum tratamento, $\mathrm{Sal}+\mathrm{Dx}+\mathrm{SAB}$ e $\mathrm{VBj}+\mathrm{Sal}+\mathrm{SAB}$ do que no grupo envenenando tratado com a associação de Dx e do SAB (Figura 23B). 

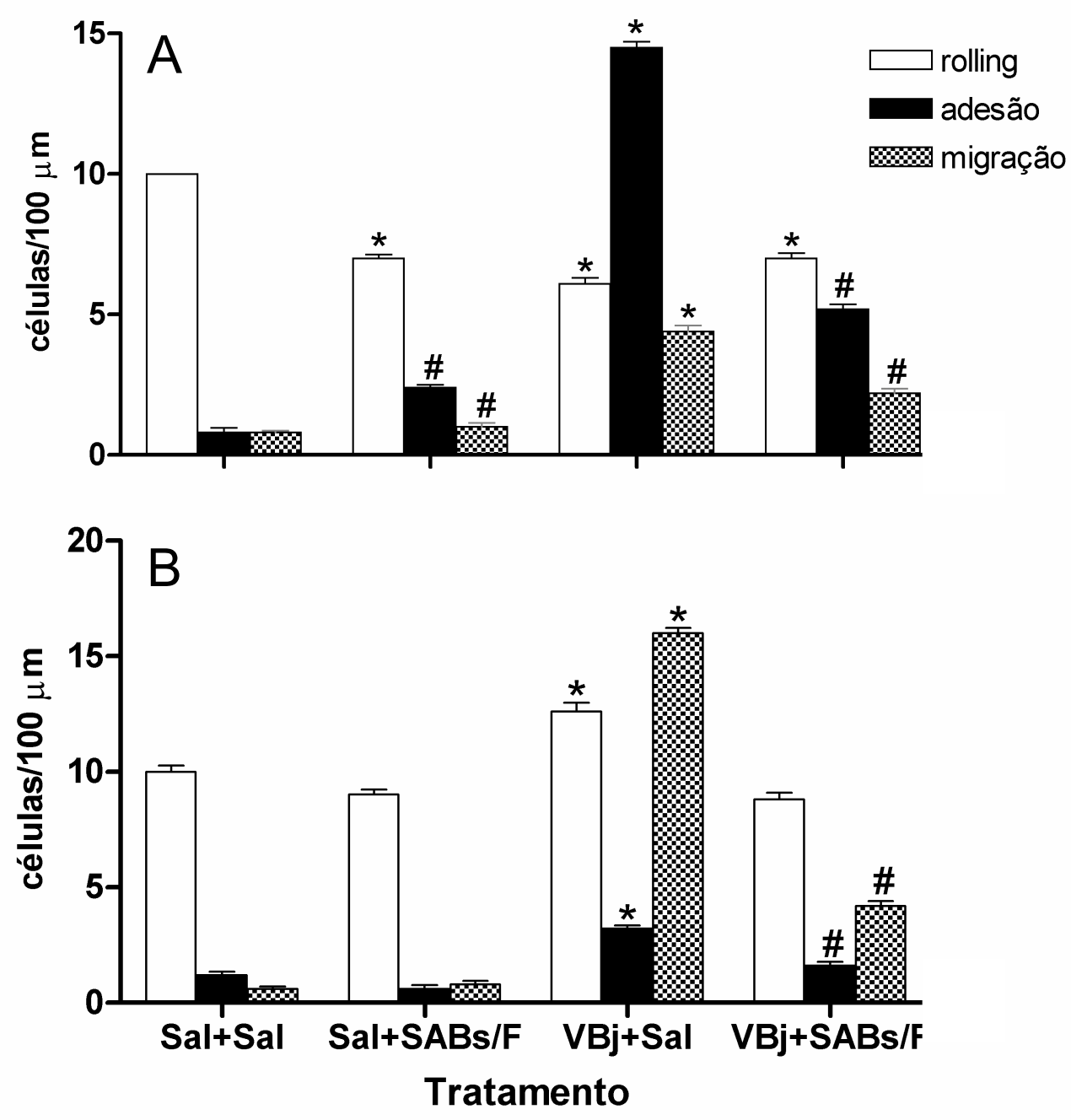

Figura 22. Efeito do pós-tratamento com soro antibotrópico sem fenol na interação leucócitoendotélio em vênulas pós-capilares na microcirculação do músculo cremaster de camundongos induzido pelo veneno de Bothrops jararaca (VBj).

Os animais receberam tratamento com soro antibotrópico (SAB) sem fenol (SABs/F, 200 $\mu \mathrm{L}$ i.v.) ou salina (Sal), $1 \mathrm{~h}$ após da injeção de $\mathrm{VBj}(1 \mu \mathrm{g} / 100 \mu \mathrm{L})$ ou salina no subcutâneo da bolsa escrotal. Após $2 \mathrm{~h}(\mathrm{~A})$ ou 24h (B) da injeção do $\mathrm{VBj}$, o músculo cremaster foi exposto e os eventos celulares (rolling, adesão e migração) foram avaliados por microscopia intravital. Resultados correspondem à média \pm e.p.m. $(n=5$ animais por grupo). ${ }^{*} \mathrm{p}<0,05$ por comparação ao grupo controle (Sal+Sal); \#p $<0.05$ em comparação aos outros grupos. 

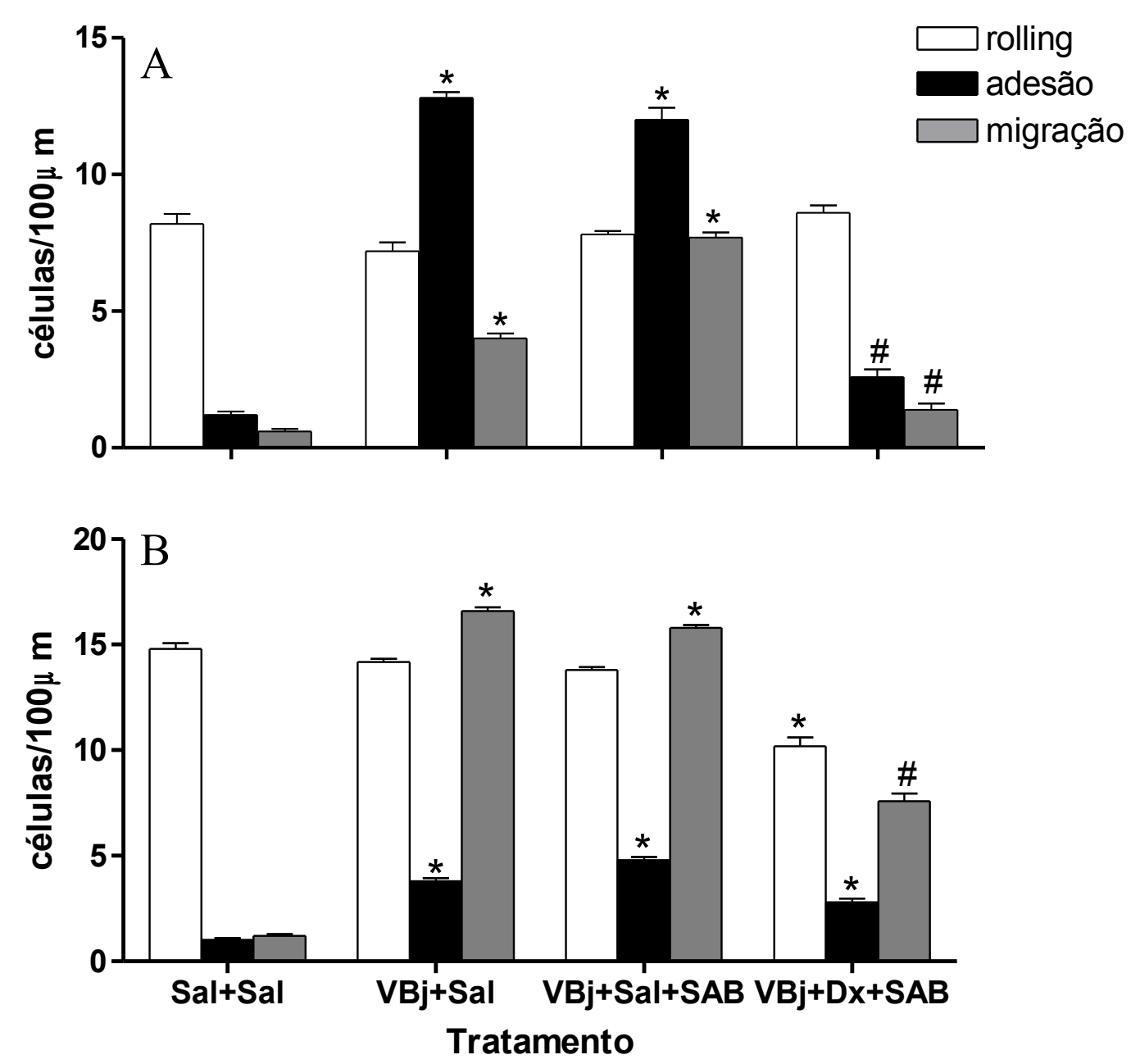

Figura 23. Efeito da associação de dexametasona com soro antibotrópico na interação leucócitoendotélio em vênulas pós-capilares na microcirculação do músculo cremaster de camundongos induzido pelo veneno de Bothrops jararaca (VBj).

Os animais receberam tratamento com dexametasona (Dx, $1,0 \mathrm{mg} / \mathrm{kg}$ i.p.), SAB (200 $\mu \mathrm{L}$, i.v.) ou salina (Sal, i.v. ou i.p.), 1h após a injeção de $\operatorname{VBj}(1 \mu \mathrm{g} / 100 \mu \mathrm{L})$ ou salina no subcutâneo da bolsa escrotal. Após $2 \mathrm{~h}$ (A) ou 24h (B) do envenenamento, o músculo cremaster foi exposto e os eventos celulares (rolling, adesão e migração) foram avaliados por microscopia intravital. Resultados correspondem à média \pm e.p.m. $(\mathrm{n}=5$ animais por grupo). ${ }^{*} \mathrm{p}<0,05$ por comparação ao grupo controle $(\mathrm{Sal}+\mathrm{Sal})$; $\# \mathrm{p}<0.05$ em comparação aos outros grupos. 


\section{DISCUSSÃO}

Apesar da eficiência da soroterapia em neutralizar os sintomas sistêmicos, as reações locais induzidas pelos venenos botrópicos nem sempre respondem satisfatoriamente a esse tratamento. Tal fato se deve à rápida manifestação destas reações locais e pelo fato de que os antivenenos não são capazes de reverter às lesões já estabelecidas ou desencadeadas, e nem de neutralizar os mediadores endógenos que participam do processo (Rosenfeld, 1971). O fato de a soroterapia ser pouco eficaz no tratamento das reações locais induzidas pelos venenos botrópicos estimula a procura de tratamentos complementares que possibilitem a melhora desse quadro, para tanto se faz necessário um maior entendimento da reação inflamatória inicial que ocorre após o envenenamento. Assim, o presente trabalho visou uma melhor caracterização da fase inicial da resposta inflamatória, a qual envolve a interação leucócitoendotélio.

Os resultados obtidos no presente trabalho corroboram as observações clínicas de que o veneno de Bothrops jararaca (VBj) induz reações locais de grande magnitude e que se instalam rapidamente (Rosenfeld, 1971; Cardoso et al., 1993; França e Málaque, 2003). O VBj induziu alteração dos parâmetros de interação leucócito-endotélio, logo nos primeiros minutos após a injeção. As alterações observadas, tais como diminuição significativa de células em rolling, acompanhado de um aumento de células aderidas, foram coerentes com resultados anteriores observados em ratos (Farsky et al., 1999). A partir dos resultados obtidos pela cinética temporal do efeito do VBj na interação leucócito-endotélio, os tempos de 2 e 24 $\mathrm{h}$ foram selecionados, por serem tempo representativos de predomínio de adesão (2h) e de migração celular $(24 \mathrm{~h})$ isoladamente, para posterior análise frente aos diferentes tratamentos.

Os resultados obtidos por venenos com metaloproteases, serinoproteases e FLA 2 inibidos sugerem fortemente que, dentre os componentes do veneno, as metaloproteases contribuem de forma mais significativa para os eventos inflamatórios analisados, uma vez que a inibição dessa classe de proteases no veneno de jararaca resultou em uma diminuição expressiva de células aderidas e migradas, em comparação aos mesmos parâmetros induzidos pelo veneno total.

Do veneno de serpentes Bothrops jararaca foram isoladas nove metaloproteases hemorrágicas (Mandelbaum et al., 1988; Maruyama et al., 1992; 1993; Paine et al., 1992), sendo a jararagina a mais bem estudada (Paine et al., 1992). Essa toxina, com massa molecular de $52 \mathrm{kDa}$ e ponto isoelétrico de 4.5 , possui sítio de ligação de zinco, domínio rico 
em cisteína e domínio tipo-disintegrina. Essa toxina apresenta homologias com enzimas da família ADAM (a disintegrin and metalloproteinase), mais especificamente com a ADAM 17, na qual se inclui a enzima conversora do fator de necrose tumoral (TACE). Verificou-se que a jararagina é capaz de induzir uma liberação endógena de TNF- $\alpha$ e que inibidores dessa citocina são capazes de inibir a atividade dermonecrosante do veneno (Moura-da-Silva et al., 1996; Clissa et al., 2001). Além disso, a jararagina induz hemorragia, hiperalgesia e edema de pata em camundongos. A inibição desta metaloprotease com EDTA ou outros inibidores, resultou em diminuição dos efeitos hiperalgésico e edematogênico e na supressão da atividade hemorrágica (Dale et al., 2004; Gonçalves e Chudzinki-Tavassi, 2004). Outros estudos também sugerem a participação de metaloproteases no edema induzido por venenos botrópicos (Trebien e Calixto, 1989; Perales et al., 1992; Chaves et al., 1995; Stroka et al., 2005).

Também foi observado que metaloproteases presentes no veneno de Bothrops asper estão associadas à desgranulação de mastócitos, ao aumento do número de macrófagos e a liberação de citocinas (Rucavado et al., 1998, 1999, 2002). Este veneno, quando injetado na cavidade peritoneal de camundongos, induz um aumento dos níveis de IL-1, acompanhado do aumento da expressão de moléculas de adesão de leucócitos (Teixeira et al., 2005). As metaloproteases presentes nos venenos de Bothrops asper são também responsáveis pela ativação do sistema complemento, resultando em um aumento de migração celular (Farsky et al., 2000). O sistema complemento também é ativado pelo veneno de B. jararaca (Farsky et al., 1997), possivelmente também pela ação de metaloproteases.

Além das metaloproteases, o veneno de B. jararaca possui toxinas classificadas como miotoxinas, as quais possuem estrutura homóloga a $\mathrm{FLA}_{2}$, porém podem ou não apresentar atividade enzimática, dependendo do aminoácido presente na posição 49 da proteína. As miotoxinas que possuem um aspartato nessa posição (Asp49) apresentam potente atividade enzimática. Por outro lado, as miotoxinas que possuem uma lisina (Lys49), apresentam pouca ou nenhuma atividade enzimática. Apesar disso, ambas possuem potente atividade miotóxica (Gutiérrez e Lomonte, 1995). Trabalhos mostram que toxinas homólogas as FLA 2 (miotoxinas) induzem edema, migração celular e hiperalgesia (Landucci et al., 1998; Castro et al., 2000; Chacur et al., 2003).

Uma vez que a atividade miotóxica pode alterar parâmetros de interação celular, fomos avaliar o papel das $\mathrm{FLA}_{2}$ presente no $\mathrm{VBj}$ na interação leucócito-endotélio. Os resultados obtidos com veneno inibido de $\mathrm{FLA}_{2}$ não demonstraram diminuição significativa 
dos eventos celulares analisados. Estes dados estão de acordo com os observados por outros autores, que demonstram que a inibição da atividade enzimática de $\mathrm{FLA}_{2}$ de venenos botrópicos não resulta na diminuição de influxo de neutrófilos, indicando que a atividade inflamatória não depende da atividade catalítica dessas toxinas (Castro et al., 2000; Teixeira et al., 2003). Porém, outros autores mostram que a inibição de $\mathrm{FLA}_{2}$, obtida pelo tratamento com $p$-BPB, inibiu a atividade edematogênica e a hiperalgésica de alguns venenos botrópicos (Landucci et al., 1998; Chacur et al., 2003).

Diferentemente de outros venenos botrópicos, o veneno de Bothrops jararaca apresenta concentrações muito baixas de $\mathrm{FLA}_{2}$ e/ou miotoxinas (Moura da Silva et al., 1991). Além disso, uma $\mathrm{FLA}_{2}$ com atividade enzimática, mas sem atividade inflamatória (edematogênica) foi isolada do veneno dessa serpente (Serrano et al., 1999). Talvez, essa classe de enzimas tenha uma maior participação nos eventos inflamatórios induzidos por venenos com uma concentração maior de $\mathrm{FLA}_{2}$ em sua composição, como nos venenos de Bothrops asper, B. jararacussu, B. moojine e B. neuwiedi (Moura da Silva et al., 1991, Gutiérrez e Lomonte, 1995).

Outra classe se protease presente no veneno de Bothrops jararaca são as serinoproteases, as quais do são capazes de induzir a liberação de bradicinina (Rocha e Silva et al., 1949). Esse peptídeo é capaz de induzir inflamação local. Porém, resultados de Trebien e Calixto (1989), mostraram que o tratamento com captopril, inibidor da degradação da bradicinina, em ratos não alterou o edema induzido por $\mathrm{VBj}$, sugeriu que as cininas não participam do edema de pata induzido por VBj. Em outro estudo, observou-se uma redução na formação de edema induzido por $\mathrm{VBj}$, quando este é pré-aquecido por 5 min a $100{ }^{\circ} \mathrm{C}$, antes da injeção em camundongos. Porém, quando o VBj é aquecido por mais 10 min à mesma temperatura, não é observada redução adicional do edema. De acordo com a interpretação dos autores, estes resultados sugerem que a formação de edema depende de enzimas proteolíticas termo-lábeis, como as metaloproteases, mas não de proteínas termosestáveis, como serinoproteases presentes no veneno, tais como as toxinas tipo-trombina ou cininogenases (Perales et al., 1992).

Os resultados obtidos com o veneno tratado com PMSF, inibido de serinoprotroteases, indicam que essas proteases possuem um papel pouco significativo na alteração da interação leucócito-endotélio induzido pelo veneno de Bothrops jararaca. 
De fato, a bradicinina participa de outros processos inflamatórios induzidos por VBj, como a dor (Chacur et al., 2002) e a artrite (Guzzo et al., 2000). Efeitos patológicos induzidos por este veneno podem possuir mediações farmacológicas distintas. Como exemplo podemos citar o efeito hiperalgésico causado pelo VBj possui mediação distinta da atividade edematogênica (Teixeira et al., 1994), bem como a atividade edematogênica possui mediação diferente da hemorrágica (Gonçalves e Mariano, 2000).

Como citado anteriormente, a reação inflamatória observada no VBj é devida a uma ação rápida das toxinas contidas no veneno e também pela rápida liberação de mediadores endógenos.

Ao pré-tratarmos os animais com prometazina, inibidor de histamina, nenhuma alteração na interação leucócito-endotélio foi observada após a injeção do veneno, sugerindo que esta amina não medeia a interação leucócito-endotélio induzida pelo veneno de Bothrops jararaca. Estudos demonstram que esse mediador também não participa da mediação do edema de pata induzido por esse veneno em camundongos (Perales et al., 1992; Gonçalves e Mariano, 2000). Já em ratos, é verificada a participação da histamina na mediação desse edema (Trebien e Calixto, 1989).

Também não foram observadas diferenças nos parâmetros da interação leucócitoendotélio induzida por $\mathrm{VBj}$ em animais pré-tratados com metissergida, inibidor de serotonina, sugerindo também a serotonina não participa nesse processo.

Os glicocorticóides são potentes imunossupressores e antiinflamatórios e são agentes efetivos em controlar processos inflamatórios crônicos, doenças alérgicas, no tratamento de doenças autoimunes e na rejeição de transplantes (Barnes et al., 1993; Jianping et al., 2001). Este grupo de antiinflamatórios atua no aumento da produção de lipocortina-1, que por sua vez inibe a expressão da $\mathrm{FLA}_{2}$, impedindo a expressão de mediadores derivados do metabolismo do ácido araquidônico, tais como, prostaglandinas e leucotrienos (Barnes et al., 1993).

Ao tratarmos os animais com o antiinflamatório dexametasona (Dx), inibidor da fosfolipase $A_{2}$, $1 \mathrm{~h}$ antes ou $1 \mathrm{~h}$ após a injeção do VBj observou-se um aumento de células em rolling e uma expressiva diminuição de células aderidas e migradas, após 2 da injeção do VBj. Vinte e quatro horas após o envenenamento, o grupo tratado apresentou uma diminuição em todos os parâmetros (rolling, adesão e migração), sugerindo a participação de eicosanóides na mediação destes eventos. 
Os eicosanóides originados da via da ciclooxigenase, mas aparentemente não os originados na via das lipoxigenase, participam da mediação da interação leucócito endotélio induzidos pelo VBj. Trabalhos demonstram a participação de produtos originados pelos eicosanóides na migração celular induzida pelo veneno de B. jararaca (Burigo et al., 1996). Ainda com relação ao papel dos glicocorticóides no recrutamento leucocitário, tem sido descrito que glicocorticóides reduzem o recrutamento de células para o local da inflamação por inibição de moléculas de adesão, pois induzem uma mudança rápida na superfície das CAMs, possivelmente por um mecanismo genômico (Czock et al., 2005), ou interferindo com a expressão da molécula de adesão ICAM-I e KC (quimiocina derivada de mastócito) na aderência de leucócitos induzida por IL-1 $\beta$ no mesentério de rato (Tailor et al., 1999). Sabese que a migração de células inflamatórias induzidas pelos venenos botrópicos é mediada principalmente por eicosanóides e que esse recrutamento é dependente da expressão de moléculas de adesão como ICAM-1, LECAM-1, LFA-1 (Lymphocyte function associated antigen-1), PECAM-1, mas não de MAC-1 (Flores et al., 1993, Burigo et al., 1996, Zamuner et al., 2002).

A expressão dessas moléculas de adesão resulta em uma maior interação leucócitoendotélio, primeiro passo antes do processo de diapedese de células inflamatórias (Rampart, 1994), e isso pode estar refletindo nas modificações dos eventos celulares observados após a injeção do VBj.

Zang e Thorlacius (2000) observaram que o pré-tratamento com dexametasona (Dx) induz diminuição de células em rolling em arteríolas, mas não em vênulas do músculo cremaster de camundongos injetados com TNF- $\alpha$. Isso pode ocorrer devido à expressão de várias selectinas (P-, E - e L-selectina), sendo que em arteríola há somente expressão de Pselectina, sugerindo que a Dx inibe a expressão de P-selectina e conseqüente diminuição de células aderidas.

Os resultados obtido com o pré-tratamento com indometacina (inibidor da via da ciclooxigenase) e com celecoxib (inibidor específico da COX-2) reforçam a importância da participação da via da ciclooxigenase, principalmente da COX-2 na mediação da interação leucócito-endotélio induzido pelo $\mathrm{VBj}$, uma vez que estes fármacos mostraram-se bastante eficazes em inibir o eventos celulares induzido pelo veneno, sendo observado uma significativa diminuição de células aderidas na $2^{\mathrm{a}}$ hora e migradas na $24^{\mathrm{a}}$ hora em relação aos grupos injetados com o veneno sem tratamento. 
Estes resultados estão de acordo com Trebien e Calixto (1989) e com Gonçalves e Mariano (2000) que demonstraram a participação de produtos da via da ciclooxigenase na formação de edema de pata induzido por VBj em ratos. Essa participação também foi observada em camundongos, tanto para produtos da via da ciclooxigenase como para a isoforma COX-2 (Olivo et al., 2007).

Apesar dos leucotrienos interagirem com receptores da superfície de neutrófilos resultando em quimiotaxia e um aumento de adesão à células endoteliais, através principalmente do aumento da expressão da $\beta_{2}$ integrina (Palmblad et al., 1990), estes produtos da via da lipoxigenase, aparente uma não participação na mediação induzida pelo $\mathrm{VBj}$, já que o tratamento dos animais com NDGA, inibidor da via da lipoxigenase, e conseqüente inibição da liberação dos leucotrienos não apresentou efeito inibitório nos parâmetros de rolling, adesão e migração celular. Apesar de leucotrienos B4 ser um dos principais agentes quimiotáticos em processos inflamatórios, aparentemente não participam da mediação de adesão e migração induzidas pelo veneno de $B$. jararaca, no presente modelo experimental. Por outro lado, os produtos derivados da via da lipoxigenase participam da migração induzida pelo veneno de B. erythromelas e B. alternatus (Flores et al., 1993).

Sabe-se que citocinas como o TNF- $\alpha$ e IL-1 $\beta$ são liberados nos envenenamentos por Bothrops jararaca (Moura-da-Silva et al., 1996; Petricevich et al., 2000). Dentre estas citocinas, o TNF- $\alpha$ tem sido relacionado com a necrose local induzida pelo veneno de Bothrops jararaca (Moura-da-Silva et al., 1996; Clissa et al., 2001) . O TNF- $\alpha$ é considerado um componente chave na resposta inflamatória devido a sua capacidade de influir em vários pontos desse processo, como induzindo a síntese de novas citocinas, induzindo a expressão de moléculas de adesão principalmente VCAM-1 e ICAM-1 e, assim, aumentando a interação leucócito-endotélio e a permeabilidade vascular (Luscinskas, 1991; Kumar et al., 2005; Anjos-Valotta et al., 2006). Estudos experimentais demonstram que a utilização de inibidores de TNF- $\alpha$ diminui ou inibem processos necróticos e manifestações hemodinâmicas (Mourada-Silva et al., 1996) . Os resultados observados com o tratamento com pentoxifilina, inibidor de fofodiesterase que reduz seletivamente a concentração de mRNA para TNF- $\alpha$, indicam a participação de citocinas, particularmente a participação de TNF- $\alpha$ nesse processo.

Alguns dados na literatura demonstram que o mediador óxido nítrico (NO) apresenta um papel modulador na interação leucócito-endotélio, e inibidores seletivos das isoformas das enzimas óxido nítrico sintases endotelial (eNOS) e induzível (iNOS) aumentam o número dos 
eventos celulares observados na interação leucócito-endotélio (Kubes et al.,1991; Dal Secco et al., 2003). Ainda, foi demonstrado que inibidores de NOS não seletivos, como L-NAME, não inibem a expressão da molécula de adesão ICAM-1, essencial para uma firme adesão do leucócito ao endotélio quando induzido por lipopolissacarídeo (LPS) ou carragenina (Dal Secco et al., 2006). Porém, nossos resultados mostraram uma diminuição expressiva dos eventos celulares na microcirculação do músculo cremaster de camundongos após o prétratamento com inibidor de NOS (L-NAME) e com o inibidor seletivo da isoforma iNOS (aminoguanidina) quando induzido por $\mathrm{VBj}$, indicando a participação destes mediadores nesta interação leucócito-endotélio.

Estes dados estão de acordo com os observado por Farsky et al. (2004), que após a aplicação tópica de VBj na fáscia espermática de ratos pré-tratados com L-NAME, apresentou uma redução do número de células em rolling e aderidas. Este inibidor também inibiu fagocitose de leucócitos na cavidade peritoneal induzido pelo veneno de Bothrops jararaca e asper (Zamuner et al., 2001). O veneno de Bothrops atrox também é descrito como indutor dos níveis séricos de NO (Barros et al., 1998). Sabe-se que citocinas como INF- $\gamma$ e TNF- $\alpha$ são responsáveis pela indução da expressão de iNOS (Ding et al., 1988), e que o veneno de Bothrops jararaca é capaz de induzir a liberação tanto dessas citocinas como de NO (Petricevich et al., 2000).

Diferentes condições experimentais, vias administração ou estímulos inflamatórios podem determinar efeitos opostos na expressão de NO, sugerindo que este mediador atue muitas vezes com uma ação antagônica em relação à resposta inflamatória (Geffner et al., 1995; Farsky et al., 2004).

Como assinalado na Introdução, os acidentes ofídicos representam um grave problema de Saúde Pública no Brasil. A eficácia da soroterapia no tratamento destes acidentes é conhecida, porém, apesar de reverter os efeitos sistêmicos e reduzir à letalidade dos envenenamentos ofídicos, as lesões locais causadas por venenos botrópicos não são bem neutralizadas pelo soro (Cardoso et al., 1993).

Foi verificado que o pré e pós-tratamento com o SAB inibiu a formação do edema induzido por VBj em camundongos (Araújo et al., 2007). No entanto essa inibição não foi observada no grupo que recebeu o SAB 45 minutos após a injeção do VBj. Esse resultado mostra que o SAB neutraliza a formação do edema, no entanto essa diminuição é mais eficiente quando o mesmo é administrado poucos minutos após o envenenamento (Araújo et 
al., 2007). O mesmo efeito foi observado por Picolo et al. (2002) que verificaram uma diminuição do edema apenas quando o SAB é administrado imediatamente antes da injeção do veneno de Bothrops jararaca no coxim plantar de ratos.

$\mathrm{Na}$ literatura existem poucos dados sobre a utilização de soros antiofídicos no evento de migração celular, por isso neste trabalho investigou-se a capacidade do soro antibotrópico em reverter às alterações induzidas pelo $\mathrm{VBj}$ na interação leucócito-endotélio. Surpreendentemente, o SAB aplicado por via i.v. induziu, per se, uma diminuição de rolling e aumento de células aderidas e migradas, alterações semelhantes às observadas em animais injetados somente com VBj na bolsa escrotal.

Nossos resultados demonstram que esse efeito "inflamatório" do SAB pode ser devido ao fenol, utilizado como conservante encontrado no antiveneno, já que a injeção i.v. deste conservante induz as mesmas alterações verificadas pela injeção do SAB, e essas alterações não foram observadas quando um SAB sem fenol foi utilizado.

Trabalhos apontam o papel do fenol na indução da resposta inflamatória Nesse sentido, Macedo et al. (2006) demonstraram que compostos fenólicos possuem atividade próinflamatória, aumentando o número de células em rolling e aderidas em mesentério de ratos. Segundo estes autores, o aumento pode ser devido uma vasoconstrição em pequenas arteríolas, bloqueando a dilatação dependente de óxido nítrico. Outros autores também questionam a presença de conservantes, como o fenol, em soros hiperimunes, pois estes podem estar contribuindo para reações adversas ao soro causadas em pacientes (Rojas et al., 1993; García et al., 2002). Sabe-se que o fenol pode interagir com as moléculas de IgG ou com os fragmentos $\mathrm{F}\left(\mathrm{ab}^{\prime}\right)_{2}$ do antiveneno, promovendo a formação de agregados protéicos ou dímeros, aumentando a turbidez do soro. García et al. (2002) verificaram que um antiveneno polivalente obtido de cavalos imunizados com venenos de Bothrops asper, Crotalus durrissus terrificus e Lachesis stenophrys, contendo fenol, induz um efeito hipotensor em ratos, quando administrados i.v. sem diluente. Esse efeito hipotensor não ocorreu na ausência de fenol ou quando o soro foi aplicado na forma diluída.

Quando injetamos SAB ou fenol i.v. em camundongos, os animais apresentaram fortes tremores e dispnéia, efeito esse, que poderia ser devido a uma reação anafilática do tipo I, efeito esse dependente dá histamina. Esta observação nos levou a fazer um prétratamento com prometazina, um anti-histamínico de primeira geração, que promove antagonismo competitivo com a histamina na ligação aos receptores $\mathrm{H}_{1}$. Verificou-se que a 
associação do anti-histamínico com o $\mathrm{SAB}$ ou com o conservante fenol, não inibiu as alterações provocadas por estes agentes. Nossos dados corroboram com outro estudo que mostra que exposição a compostos fenólicos não altera o número e atividade de mastócitos, sugerindo que o elevado número de células em rolling e aderidas não é devida a substâncias secretadas pela degranulação de mastócitos (Macedo et al., 2003) e a não participação de histamina no processo.

O SAB sem fenol inibiu expressivamente o número de células aderidas e migradas induzidas pela injeção de VBj na bolsa escrotal, demonstrando que o SAB possui anticorpos capazes de neutralizar as toxinas do veneno que induzem estas reações inflamatórias.

Alguns trabalhos sugerem que a ineficiência da soroterapia em inibir as lesões locais induzidas por venenos botrópicos, é devida a dificuldade que a imunoglobulina tem em chegar ao local da lesão (Battellino et al., 2003), o que justificaria a utilização apenas da porção Fab da IgG total, no tratamento de envenenamentos por serpentes (Landon et al., 1995). No entanto, a literatura demonstra que não há diferença significativa de diminuição das lesões locais como edema, hemorragia e mionecrose em animais submetidos a tratamentos com os três tipos de soro, constituído com a IgG total, só com a porção $\mathrm{F}\left(\mathrm{ab}{ }^{\prime}\right)_{2}$ ou ainda com a porção Fab (Gutiérrez et al., 1998; Chaves et al., 2003).

Essa ineficiência atribuída ao antiveneno descrita anteriormente estimula estudos de terapias complementares. Nesse sentido, a associação de antiinflamatórios ao soro no tratamento das reações inflamatórias locais presentes nos envenenamentos por VBj seria uma alternativa racional, que deveria ser testada experimentalmente.

Araújo et al. (2007) demonstraram uma melhora da eficiência da soroterapia na evolução do edema inflamatório induzido pelo $\mathrm{VBj}$ em camundongos, quando administrada juntamente com a dexametasona.

Nossos dados demonstram que a utilização de Dx foi benéfica em inibir os eventos celulares da interação leucócito-endotélio induzido pelo VBj, não só comparado ao grupo controle, mas também quando comparado aos grupos que receberam somente o tratamento com o SAB. As mesmas diminuições foram observadas em animais tratados com a associação de Dx e SAB, semelhantes ao observado em animais tratados somente com Dx, nos dois tempos estudados.

Sabe-se que o VBj não induz a secreção de corticóides endógenos ou a estimulação do eixo hipotálamo-pituitária-adrenal (Cury et al., 1997). Esse fato poderia explicar o edema 
inflamatório persistente observado em pacientes picados por esta serpente e o efeito benéfico da Dx observado em nosso estudo. Nesse sentido a utilização de Dx seria importante para evitar reações inflamatórias, porém este corticóide não altera as atividades hemorrágica local e coagulante do VBj, não sendo indicado o seu uso em substituição ao soro. Porém, a associação de dexametasona ao $\mathrm{SAB}$, poderia complementar o tratamento do envenenamento por Bothrops jararaca, principalmente no que se refere às reações locais observadas em pacientes picados por esta serpente.

Assim sendo, os presentes resultados indicam que as metaloproteases do veneno de Bothrops jararaca são os principais componentes responsáveis pelas alterações observadas na interação leucócito-endotélio. Essas alterações são mediadas principalmente por eicosanóides da via das ciclooxigenases e que o SAB inibe a capacidade do VBj induzir essas alterações. Entretanto, o fenol, utilizado como conservante, pode induzir efeitos não desejados.

A melhor compreensão desses fenômenos poderá contribuir para a melhoria das terapias empregadas no tratamento das lesões locais observadas nos envenenamentos botrópicos. 


\section{CONCLUSÃO}

Os resultados obtidos nos permitem concluir que:

- O veneno de Bothrops jararaca VBj é um potente agente flogístico alterando todos os parâmetros analisados na interação leucócito-endotélio do músculo cremaster de camundongos.

- Dentre os componentes deste veneno, as metaloproteases, mas não as serinoproteases e as fosfolipases $A_{2}$, contribuem de forma significativa para os eventos analisados.

- A histamina e a serotonina não participam da mediação deste evento de interação leucócito-endotélio em camundongos.

- Os mediadores derivados do ácido araquidônico, principalmente os da via da ciclooxigenase, mas não da lipoxigenase, medeiam as alterações dos eventos celulares induzidos pelo $\mathrm{VBj}$,

- O TNF- $\alpha$ e o óxido nítrico também participam dessa alteração na interação leucócitoendotélio induzido pelo $\mathrm{VBj}$.

- O soro antibotrópico (SAB) possui anticorpos capazes de neutralizar as toxinas do $\mathrm{VBj}$ que induzem alterações na interação leucócito-endotélio.

- O fenol utilizado como conservante do soro antibotrópico induz alterações semelhantes ao do VBj sem tratamento, o que levanta o questionamento de sua concentração ou utilização no SAB.

- A associação de dexametasona a soroterapia no tratamento das reações inflamatórias locais observadas nos envenenamentos por Bothrops jararaca sugerem um efeito benéfico durante aplicação terapêutica. 


\section{REFEREÊNCIAS BIBLIOGRÁFICAS*}

Alvarado J, Gutierrez JM. Anticoagulant effect of myotoxic phospholipase A2 isolated from the venom of the snake Bothrops asper (Viperidae). Rev Biol Trop. 1988;36(2B):563-5.

Anjos-Valotta EA, Martins JO, Oliveira MA, Casolari DA, Britto LRG, Tostes RC, Fortes ZB. Inhibition of tumor necrosis factor- $\alpha$-induced intercellular adhesion molecule- 1 expression in diabetic rats: role of insulin. Inflamm Res. 2006;55:16-22.

Araújo SD, De Souza A, Nunes FPB, Gonçalves LRC. Effect of dexamethasone associated to the antibothropic serum in the treatment of the paw edema induced by Bothrops jararaca venom in mice. Inflamm Res. 2007;56:409-13.

Baez S. An open cremaster muscle preparation for the study of blood vessels by in vivo microscopy. Microvasc Res. 1973;5(3):384-94.

Barbosa AM, Do Amaral RO, Teixeira CF, Hyslop S, Cogo JC. Pharmacological characterization of mouse hind paw oedema induced by Bothrops insularis (jararaca ilhoa) snake venom. Toxicon. 2003;42(5):515-23.

Barnes JP, Adcock I. Anti-inflammatory actions of steroids: molecular mechanisms. Tips. 1993;14: 436-41.

Barros SF, Friedlanskaia I, Petricevich VL, Kipini TL. Local inflammation, lethality and citokine release in mice injected with Bothrops atrox venom. Med Inflamm. 1998;7:339-46.

Battellino C, Piazza R, Da Silva AMM, Cury Y, Farsky SHP. Assessment of efficacy of bothropic antivenom therapy on microcirculatory effects induced by Bothrops jararaca snake venom. Toxicon. 2003;41(5):583-93.

Bjarnason JB, Fox JW. Hemorrhagic metalloproteinases from snake venoms. Pharmacol Ther. 1994;62(3):325-72.

Bonnans C, Vachier I, Chavis C, Godard P, Bousquet J, Chanez P. Lipoxins are potential endogenous antiinflammatory mediators in asthma. Am J Respir Crit Care Med. 2002;165: 1531-5.

*De acordo com:

International Committee of Medical Journal Editors. Uniform requirements for manuscripts submitted to Biomedical Journal: sample references. C2003 - [updated 2005 June 15; cited 2006 May 16]. Available from: http://www.nlm.nih.gov/ bsd/uniform requirements.html. 
Borkow G, Gutiérrez JM, Ovadia M. Inhibition of the hemorrhagic activity of Bothrops asper venom by a novel neutralizing mixture. Toxicon. 1997;35(6):865-77.

Búrigo AC, Calixto JB, Medeiros YS. Pharmacological profile of rat pleurisy induced by Bothrops jararaca venom. J Pharm Pharmacol. 1996;48(1):106-11.

Busconi L, Michel T. Endothelial nitric oxide synthase. J Biol Chem. 1993:268 (12):9030-3.

Butcher EC. Leukocyte-endothelial cell recognition: three (or more) steps to specificity and diversity. Cell. 1991;67(6):1033-6.

Cabral GA. Lipids as bioeffectors in the immune system. Life Sciences. 2005;77(14):1699-710.

Cardoso JL, Fan HW, França FO, et al. Randomized comparative trial of three antivenoms in the treatment of envenoming by lance-headed vipers (Bothrops jararaca) in Sao Paulo, Brazil. Q J Med. 1993;86(5):315-25.

Castro RC, Landucci ECT, Toyama MH,.Giglio JR, Marangoni S, De Nucci G, Antunes E. Leucocyte recruitment induced by type II phospholipases $A_{2}$. Toxicon. 2000;38:1775-85.

Chacur M, Picolo G, Teixeira CFP, Cury Y. Bradykinin is involved in hyperalgesia induced by Bothrops jararaca venom. Toxicon. 2002;40(7):1047-51.

Chacur M, Longo I, Picolo G, Gutierrez JM, Lomonte B, Guerra JL, Teixeira CF, Cury Y. Hyperalgesia induced by Asp49 and Lys49 phospholipase $\mathrm{A}_{2}$ from Bothrops jararaca snake venom: pharmacological mediation and molecular determinants. Toxicon. 2003;41:667-78.

Chaves F, Barbosa M, Gutiérrez JM. Pharmacological study of edema induced by venom of the snake Bothrops asper (terciopelo) in mice. Toxicon. 1995;33(1):31-9.

Chaves F, Loría GD, Salazar A, Gutiérrez JM. Intramuscular administration of antivenoms in experimental envenomation by Bothrops asper: comparison between Fab and IgG. Toxicon. 2003;41:237-44.

Clissa PB, Laing GD, Theakston RD, Mota I, Taylor MJ, Moura-da-Silva AM. The effect of jararhagin, a metalloproteinase from Bothrops jararaca venom, on pro-inflammatory cytokines released by murine peritoneal adherent cells. Toxicon. 2001;39(10):1567-73. 
Cotran RS, Kumar V, Collins T. Acute and Chronic Inflammation. Robbins pathologic basis of disease. 6 ed. Philadelphia: W. B. Saunders; c1999. p. 50-81.

Cury Y, Teixeia CF, Farsky SH. Lack of effect of endogenous corticosteroids on the acute inflammatory reaction (edema) induced by Bothrops jararaca venom $(\mathrm{BjV})$ in rats. Toxicon. 1997;35(5):773-6.

Czock D, Keller F, Rasche FM, Haussler U. Pharmacokinetics and pharmacodynamics of systemically administered glucocorticoids. Clin Pharmacokinet. 2005;44(1):61-98.

Dale CS, Goncalves L RC, Juliano L, Juliano MA, Moura da Silva AM, Giorgi R. The Cterminus of murine S100A9 inhibits hyperalgesia and edema induced by jararhagin. Peptides. 2004;25(1):81-9.

Dal Secco D, Paron JA, Oliveira SHP, Ferreira SH, Silva JS, Cunha FQ. Neutrophil migration in inflammation: nitric oxide inhibits rolling, adhesion and induces apoptosis. Nitric Oxide. 2003;9:153-64.

Dal Secco D, Moreira AP, Freitas A, Silva JS, Rossi MA, Ferreira SH, Cunha FQ. Nitric oxide neutrophil migration by a mechanism dependent on ICAM-1: Role of soluble guanylate cyclase. Nitric Oxide. 2006;15:77-86.

Dansk HM, Barlow CB, Lominska C. Adhesion of monocytes to arterial endothelium and initiation of atherosclerosis are critically dependent on vascular cell adhesion molecule-1 gene dosage. Arterioscleriosis Throbosis Vasc Biol. 2001;21:1662-7.

De Faria L, Antunes E, Bon C, De Araújo A. Pharmacological characterization of the rat paw edema induced by Bothrops lanceolatus (Fer de lance) venom. Toxicon. 2001;39(6):825-30.

Denson KW, Rousseau WE. Separation of the coagulant components of Bothrops jararaca venom. Toxicon. 1970;8(1):15-9.

Díaz-Oreiro C, Gutiérrez JM. Chemical modification of histidine and lysine residues of myotoxic phospholipases $\mathrm{A}_{2}$ isolated from Bothrops asper and Bothrops godmani snake venoms: effects on enzymatic and pharmacological properties. Toxicon. 1997;35(2):241-52.

Ding AH, Nathan CF, Stueher DJ. Release of rective nitrogen intermediates and reactive oxygen intermediates from mouse peritoneal macrophages. J Immunol.1988;141:2407-12. 
Domont GB, Perales J, Moussatche H. Natural anti-snake venom proteins. Toxicon. 1991; 29(10):1183-94.

Dusse LMS, Vieira LM, Carvalho MG. Revisão sobre óxido nítrico. J Bras Patol Méd Lab. 2003;39 (4):343-50.

Ebnet K, Vestweber D. Molecular mechanisms that control leukocyte extravasation: the selectins and the chemokines. Histochem Cell Biol. 1999;112(1):1-23.

Edwards MJ, Todd Heniford B, Klar EA, Doak KW, Miller FN. Pentoxifylline inhibits interleukin-2-induced toxicity in C57BL/6 mice but preserves antitumor efficacy. J Clin Invest. 1992;90:637-41.

Erlanger BF, Kokowsky N, Cohen W. The preparation and properties of two new chromogenic substrates of trypsin. Arch Biochem Biophys. 1961;95:271-8.

Escalante T, Franceschi A, Rucavado A, Gutiérrez JM. Effectiveness of batimastat, a synthetic inhibitor of matrix metalloproteinases, in neutralizing local tissue damage induced by $\mathrm{BaP} 1$, a hemorrhagic metalloproteinase from the venom of the snake Bothrops asper. Biochem Pharmacol. 2000;60:269-74.

Fan HW, Marcopito LF, Cardoso JLC, et al. Seuqential randomised and double blind trial of promethazine prophylaxis against early anaphylaxis reactions to antivenom for bothrops snakebite. BMJ. 1999;318:1451-2.

Fan HW. Soroterapia. In: Cardoso JL, França FOS, Wen FH, Málaque CMS, Haddad Jr V, editors. Animais peçonhentas no Brasil: biologia. Clínica e terapêutica dos acidentes. São Paulo: Savier; 2003. pp 380-93.

Farsky SH, Walber J, Costa-Cruz M, Cury Y, Teixeira CF. Leukocyte response induced by Bothrops jararaca crude venom: in vivo and in vitro studies. Toxicon. 1997;35(2):185-93.

Farsky SH, Goncalves LRC, Cury Y. Characterization of local tissue damage evoked by Bothrops jararaca venom in the rat connective tissue microcirculation: an intravital microscopic study. Toxicon. 1999;37(7):1079-83.

Farsky SH, Gonçalves LRC, Gutiérrez JM, Correa AP, Rucavado A, Gasque P, Tambourgi DV. Bothrops asper snake venom and its metalloproteinase BaP-1 activate the complement system. Role in leucocyte recruitment. Med Inflamm. 2000;9:213-21. 
Farsky SH, Borelli P, Fock RA, Proto SZ, Ferreira Jr JMC, Mello SBV. Chronic blockade of nitric oxide biosynthasis in rats: effect on leukocyte endothelial interaction and on leukocyte recrutaiment. Inflamm Res. 2004;53:442-52.

França FOS, Málaque CMS. Acidente botrópico. In: Cardoso JL, França FOS, Wen FH, Málaque CMS, Haddad Jr V, editors. Animais peçonhentos no Brasil: biologia, clínica e terapêutica dos acidentes. São Paulo: Savier; 2003. pp 72-86.

Flores CA, Zappellini A, Prado-Franceschi J. Lipoxygenase-derived mediators may be involved in in vivo neutrophil migration induced by Bothrops erythromelas and Bothrops alternatus venoms. Toxicon. 1993;31(12):1551-9.

Fox JW, Serrano SMT. Structural considerations of the snake venom metalloproteinases, key members of the M12 reprolysin family of metalloproteinase. Toxicon. 2005;45:969-85.

Furukawa Y, Hayashi K. Factor X converting and thrombin-like activities of Bothrops jararaca snake venom. Toxicon. 1977;15(2):97-105.

García M, Monge M, León G, Lizano S, Segura E, Solano G, Rojas G, Gutiérrez JM. Effect of preservatives on IgG aggregation, complement-activating effect and hypotensive activity of horse polyvalent antivenom used in snakebite envenomation. Biologicals. 2002; 30:143-51.

Gavins FNE, Chatterjee BE. Intravital microscopy for the study of mouse microcirculation in anti-inflammatory drug research: Focus on the mesentery and cremaster preparations. J Pharmacol Toxicol Methods. 2004;49:1-14.

Geffner JR, Analía ST, D’Elia I, Diament M, Klein D, Giordano M. Involvement of nitric oxide in the regulation of peripheral blood leukocyte counts. J Leuk Biol. 1995;58:391-4.

Godson C, Mitchell S, Havey K, Petasis N, Hogg N, Brady H. Cutting edge: lipoxins rapidly nonphogistic of apoptotic neutrophils by monocyte-derived macrophages. J Immunol. 2000;164:1663-7.

Gonçalves LRC, Mariano M. Local haemorrhage induced by Bothrops jararaca venom: relationship to neurogenic inflammation. Med Inflamm. 2000;9(2):101-7.

Gonçalves LRC, Chudzinski-Tavassi AM. High molecular mass kininogen inhibits metaloproteases of Bothrops jararaca snake venom. Bioch Biophys Res Commun. 2004; 318:53-9. 
Guimarães AQ, Cruz-Hofling MA, Ferreira De Araújo PM, Bom C, Lobo De Araújo A. Pharmacological and histopathological characterization of Bothrops lanceolatus (Fer de lance) venom-induced edema. Inflamm Res. 2004;53(7):284-91.

Gutiérrez JM, Gene JA, Rojas G, Cerdas L. Neutralization of proteolytic and hemorrhagic activities of Costa Rican snake venoms by a polyvalent antivenom. Toxicon. 1985;23(6):887-93.

Gutiérrez JM, Lomonte B. Local tissue damage induced by Bothrops snake venoms. A review. Mem. Inst. Butantan. 1989;51:211-23.

Gutiérrez JM, Lomonte B. Phospholipase A2 myotoxins from Bothrops snake venoms. Toxicon. 1995;33(11):1405-24.

Gutiérrez JM, Leon G, Rojas G, Lomonte B, Rucavado A, Chaves F. Neutralization of local tissue damage induced by Bothrops asper (terciopelo) snake venom. Toxicon. 1998; 36(11):1529-38.

Gutiérrez JM, Rucavado A, Ovadia M. Metalloproteinase inhibitors in snakebite envenomations. Drug Discov Today. 1999;4(11):532-33.

Guzzo ML, Farsky SH, De Neuci G, Antunes E, Silva MA, Mello SB. Role of kinins and nitric oxide on the rabbit arthritis induced by Bothrops jararaca venom. Toxicon. 2000;38:1535-46.

Hessel B, Blomback M. The proteolytic action of the snake venom enzymes arvin and reptilase on N-terminal chain-fragments of human fibrinogen. FEBS Lett. 1971;18(2):318-20.

Huber AR, Kunkel SL, Todd RF, 3rd Weiss, S. J. Regulation of transendothelial neutrophil migration by endogenous interleukin-8. Science. 1991;254(5028):99-102.

Hynes RO. Integrins: versatility, modulation, and signaling in cell adhesion. Cell. 1992; 69(1):11-25.

Jianping P, Dianwen J, Qingqing W, Minghui Z, Dajing X, Lihuang Z, Hai Y, Xuetao C. Dexamethasone inhibits the antigen presentation of dendritic cells in MHC class II pathway.Immunology Letters. 2001;76:153-61. 
Kamiguti AS, Slupsky JR, Zuzel M, Hay CR. Properties of fibrinogen cleaved by Jararhagin, a metalloproteinase from the venom of Bothrops jararaca. Thromb Haemost. 1994;72(2):244-9.

Kamiguti AS, Hay CR, Zuzel M. Inhibition of collagen-induced platelet aggregation as the result of cleavage of $\alpha 2 \beta 1$-integrin by the snake venom metalloproteinase jararhagin. Biochem J. 1996;320:635-41.

Kondo H, Kondo S, Ikezawa H, Murata R, Ohsaka A. Studies on the quantitative method for determination of hemorrhagic activity of Habu snake venom. Japan. J Med Sci Biol. 1960;13:53-1.

Kubes P, Suzuki M, Granger DN. Nitric Oxide: An endogenous modulator of leukocyte adhesion. Proc Natl Acad Sci USA. 1991;88:4651-55.

Kumar V, Abbas AK, Fausto N. Robbins e Cotran. Patologia- Bases patológicas das doenças. 7 ed. Rio de Janeiro: Elsevier, 2005. p. 49-79.

Landon J, Smith DC. Development of novel antivenoms based on specific ovine Fab. In: Bon C, Goyffon M, editors. Evenomings and their treatments. Lyon: Editions Foudation Maecel Mérieux; 1995. p. 173.

Landucci ECT, Castro RC, Pereira MF, Cintra ACO, Giglio JR, Marangoni S, Oliveira B, Cirino G, Antunes E, De Nucci G. Mast cell degranulaton induced by two phospholpase $\mathrm{A}_{2}$ homologues: Dissociation between enzymatic and biological activities. Eur J Pharmacol. 1998;343:257-63.

Leon G, Estrada R, Chaves F, Rojas G, Ovadia M, Gutiérrez JM. Inhibition by CaNa2EDTA of local tissue damage induced by Bothrops asper (terciopelo) venom: application in horse immunization for antivenom production. Toxicon. 1998;36(2):321-31.

Levy BD, Romano M, Chapman HA, Relly JJ, Dazen J, Serhan CN. Human alveolar macrophages have 15-lipoxygenase and generate 15(S)-hydroxyl-5,8,11 cis-13-transeicosatetraenoic acid and lipoxinas. J Clin Invest. 1993;92,1572-79.

Lomonte B, Tarkowski A, Hanson LA. Host response to Bothrops asper snake venom. Analysis of edema formation, inflammatory cells, and cytokine release in a mouse model. Inflamm. 1993;17:93-105. 
Luscinskas FW, Cybulsky MI, Kiely JM, Peckins CS, Davis VM, Gimbrone Jr MA. Citokineactived human endothelial monolayers support enhaced neutrophil transmigration via a mechanism involving both endothelial-leukocyte adhesion molecule-1 and intercellular adhesion molecule-1. J Immunol. 1991;146:1617-25.

Macedo SM, Lourenco EL, Borelli P, Fock JM, Farsky SHP. Effect of in vivo phenol or hydroquinone exposure on events related to neutrophil delivery during an inflammatory response. Toxicology. 2006;220(2-3):126-35.

Majno G, Palade GE, Schoefl GI. The site action of histamine and serotonin along the vascular tree: atopographic study. J Biophy Bioch. 1961;11:607-26.

Majno G, Joris I. Inflammation: The actors and their language. In: Cells, tissues and disease. Principles of general pathology. 2 ed. Nova York: Oxford University Press; 2004. p. 307-82.

Mandeulbam FR, Reichl AP, Assakura MT. Some physical and biochemical characteristics of $\mathrm{HF}_{2}$, one of the hemorragic factors in the venom of Bothrops jararaca. In: Ohsaka A, Hayashi K, Sawai Y, editors. Animal Plant and Microbial Toxins. London: Plenum Press; 1976. vol.1, $111-21$.

Mandelbaum FR, Reichel AP, Assakura MT. Isolation and characterization of a proteolytic enzyme from the venom of the snake Bothrops jararaca (Jararaca). Toxicon. 1982;20(6):955-72.

Mandelbaum FR, Assakura MT. Antigenic relationship of hemorrhagic factors and proteases isolated from the venoms of three species of Bothrops snakes. Toxicon. 1988; 26(4):379-85.

Maruyama M, Sugiki M, Yoshida E, Mihara H, Nakajima, N. Purification and characterization of two fibrinolitic enzymes from Bothrops jararaca (jararaca) venom. Toxicon. 1992;30:853-64.

Maruyama M, Tanigawa M, Sugiki M, Yoshida E, Mihara H. Purification and characterization of low molecular weight fibrinolytic/hemorrhagic enzymes from snake (Bothrops jararaca) venom. Enzyme Protein. 1993;47:124-35.

Melgarejo AR. Serpentes Peçonhentas no Brasil, In: Cardoso JL, França FOS, Wen FH, Málaque CMS, Haddad Jr V, editors. Animais peçonhentos no Brasil: biologia, clínica e terapêutica dos acidentes. São Paulo: Savier; 2003. p. 289-309. 
Ministério da saúde. Manual de diagnóstico e tratamento de acidentes por animais peçonhentos. Brasília, DF: Fundação Nacional de Saúde, 2001.

Modur V, Feldhaus MJ, Weyrich AS, Jicha DL, Prescott SM, Zimmerman GA, Mcintyre TM. Oncostatin $\mathrm{M}$ is a proinflammatory mediator. In vivo effects correlate with endothelial cell expression of inflammatory cytokines and adhesion molecules. J Clin Invest. 1997; 100(1):158-68.

Moncada S, et al. Endothelium-derived relaxing factor: indetification as nitric oxide and role en the control of vascular tone and platelet. Biochm. Pharmacol. 1988;37:3495-501

Moncada S. The L-arginine: Nitric oxide pathway. Acta Physiol Scand. 1992;145:2001.

Moreira L, Borkow G, Ovadia M, Gutiérrez JM. Pathological changes induced by BaH1, a hemorrhagic proteinase isolated from Bothrops asper (terciopelo) snake venom, on mouse cappilary blood vessels. Toxicon. 1994;32:976-87.

Moura-da-Silva AM, Desmond H, Laing G, Theakston RDG. Isolation and comparison of myotoxins isolated from venoms of different species of Bothrops snakes. Toxicon. 1991; 29(6):713-23.

Moura-da Silva AM, Laing GD, Paine MJ, Dennison JM, Politi V, Cramptom JM, Theakston RD. Processingof pro-tumor necrosis factor-alpha by venom metalloproteinase: a hypothesis explaining local tissue damage follwing snakebite. Eur J Immunol. 1996;26:2000-5.

Nathan C. Points of control in inflammation. Nat Insight Rev. 2002;420(19/26):846-52.

Oda T, Katoki M, Hatanaka K, Nagai Y. Inhibition of matrix metalloproteinase: analysis by intravital microscopic. Med Inflamm. 1995;4:133-7.

Olivo RA, Teixeira CFP, Wallace JL, Gutiérrez JM, Zamuner SR. Role of cyclooxigenases in oedema-forming activity of bothropic venoms. Toxicon. 2007;49:670-7

Osborn L. Leukocyte adhesion to endothelium in inflammation. Cell. 1990;62:3-6.

Ownby CL, Bjarnason J, Tu AT. Hemorrhagic toxins from rattlesnake (Crotalus atrox) venom. Pathogenesis of hemorrhage induced by three purified toxins. Am J Pathol. 1978;93(1):201-18. 
Paine MJI, Desmond HP, Theakston RGD, Crampton JM. Purification, cloning and molecular characterization of high molecular weight hemorrhagic metalloproteinase, jararhagin, from Bothrops jararaca venom. J Biol Chem. 1992;267:22869-76.

Palmblad J, Lindstron P, Lemer R. Leukotriene B4 induced hyperadhesiveness of endothelial cells for neutrophils. Biochem Biophys Res Commun. 1990;166(2) 848-51.

Perales J, Amorim CZ, Rocha SLG., Domont GB, Moussatché H. Neutralization of the oedematogenic activity of Bothrops jararaca venom on the mouse paw by an antibothropic fraction isoled from opossum (Didelphis marsupialis) serum. Agents Actions. 1992; $37: 250-9$.

Perez JC, Sanchez EE. Natural protease inhibitors to hemorrhagins in snake venoms and their potential use in medicine. Toxicon. 1999;7:703-28.

Petricevich VL, Teixeira CF, Tambourgi DV, Gutiérrez JM. Increments in serum cytokine and nitric oxide levels in mice injected with Bothrops asper and Bothrops jararaca snake venoms. Toxicon. 2000;38:1253-66.

Picolo G, Chacur M, Gutiérrez JM, Teixeira CF, Cury Y. Evaluation of antivenoms in the neutralization of hyperalgesia and edema induced by Bothrops jararaca and Bothrops asper snake venoms. Braz J Med Biol Res. 2002;35(10):1221-8.

Ptzalis C, Pipitone N, Perretti M. Regulation of Leukocyte-Endothelial Interactions by Glucocorticoids. Annals of the N.Y. Acad Sci. 2002;966:108-18.

Radvanyui FR, Bon C. Catalytic activity and reactivity with p-bromophenacyl bromide of the phospholipase subunit of crotoxin. Influence of dimerization and association with the noncatalytic subunit. J Bio Chem. 1982;257(21):12616-23.

Radomski MW, et al. An L-arginine: nitric oxide pathway present in human platelets regulates aggregation. Proc Nat Acad Sci USA. 1990;87:5193-7.

Randolph GJ, Furie MB. A soluble gradient of endogenous monocyte chemoattractant protein-1 promotes the transendothelial migration of monocytes in vitro. J Immunol. 1995; 155(7):3610-8.

Rampart M. Neutrophil-Endothelial Cell Interations. In: Brain SD. The Handbook of Immunopharmacology. Immunopharmacology of Microcirculation. San Diego: Academic Press; 1994. 
Ramos OHP, Selistre-de-Araújo HS. Snake venom metalloproteinases- structure and function of catalytic and disintegrin domains. Comp Biochem Physiol C Comp Pharmacol. 2006;142:328-46.

Rang HP, Dale MM, Ritter JM, Moore PK. Farmacologia. 5 ed. Rio de Janeiro: Eselvier; 2004.

Rankin J. A. Biological mediators of acute inflammation. AACN Clin Issues. 2004;15(1):3-17.

Rocha e Silva M, Beraldo WT, Rosenfeld G. Bradykinin, a hypotensive and smooth muscle stimulating factor released from plasma. Am J Physiol. 1949;156:261-73.

Rocha e Silva M, Garcia-Leme J. Chemical mediators of the acute inflammatory reaction: Oxford: Pergamon Press; 1972. pp.1-47.

Rosenfeld G. Symptomatology, pathology and treatment of snake bites in South America. In: WB EB, editor. Venomous Animals and their Venoms. New York: Academic Press; 1971; vol. 2, p. 345-84.

Rojas G, Marianel V, Robles A, Gutiérrez JM. Turbidity of hyperimmune equine antivenom: the role of phenol and serum lipoproteins. Toxicon. 1993;31(1):61-6.

Rucavado A, Nunez J, Gutiérrez JM. Blister formation and skin damage induced by BaP1, a haemorrhagic metalloproteinase from the venom of the snake Bothrops asper. Int J Exp Pathol. 1998;79(4):245-54.

Rucavado A, Flores-Sanchez E, Franceschi A, Magalhaes A, Gutiérrez JM. Characterization of the local tissue damage induced by LHF-II, a metalloproteinase with weak hemorrhagic activity isolated from Lachesis muta muta snake venom. Toxicon. 1999; 37(9):1297-312.

Rucavado A, Escalante T, Teixeira CF, Fernandes CM, Diaz C, Gutiérrez JM. Increments in cytokines and matrix metalloproteinases in skeletal muscle after injection of tissue-damaging toxins from the venom of the snake Bothrops asper. Med Inflamm. 2002;11:121-8.

Rucavado A, Escalante T, Gutiérrez JM. Effect of the metalloproteinase inhibitor batimastat in the systemic toxicity induced by Bothrops asper snake venom: understanding the role of metalloproteinases in envenomation. Toxicon. 2004;43(4):417-24. 
Saadi S, Wrenshall LE, Platt JL. Regional manifestations and control of the immune system. Faseb J. 2002;16(8):849-56.

Sano-Martins IS, Fan HW, et al. Reliability of the simple 20 minute whole blood clotting test (WBCT20) as an indicator of low plasma fibrinogen concentration in patients envenomed by Bothrops snakes. Butantan Institute Antivenom Study Group. Toxicon. 1994;32(9):1045-50.

Seibert CS, Tanaka-Azevedo AM, Santoro ML, Mackessy SP, Torquato RJS, Lebrun I, Tanaka AS, Sano-Martins IS. Purification of a phospholipase A2 from Lonomia obliqua caterpillar bristle extract. Biochem Biophys Res Commun. 2006;342(4):1027-33.

Serhan CN, Sheppard KA. Lipoxin formation during human neutrophil-platelet interactions. Evidence for the transformation of leukotriene A4 by platelet 12-lipoxygenase in vitro. J Clin Invest. 1990;85(3):772-80.

Serhan CN, Savil J. Resolution of inflammation: the beginning programs the end. Nat Immunol. 2005;6(12):1191-7.

Serrano SM, Reich AP, Mentele R, Auerswald EA, Santoro ML, Sampaio CA, Camargo AC,

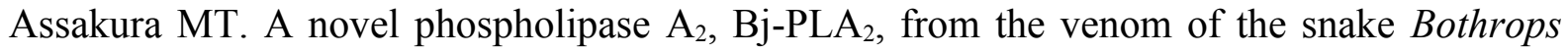
jararaca: purification, primary structure analysis, and its characterization as a plateletaggregation-inhibiting factor. Arch Biochem Biophys. 1999;367:26-32.

Springer TA. Traffic signals for lymphocyte recirculation and leukocyte emigration: the multistep paradigm. Cell. 1994;76(2):301-14.

Stroka A, Donato JL, Bon C, Hyslop S, De Araujo AL. Purification and characterization of a hemorrhagic metalloproteinase from Bothrops lanceolatus (Fer-de-lance) snake venom. Toxicon. 2005;45 (4):411-20.

Tailor A, Tomlinson A, Salas A, Panés J, Granger DN, Flower RJ, Perretti M. Dexamethasone inhibition of leukocyte adhesion to rat mesenteric postcapillary venules: role of intercellular adhseion molecule 1 and KC. Gut. 1999;45:705-12.

Tanizaki MM, Kawasaki H, Suzuki K, Mandelbaum FR. Purification of a proteinase inhibitor from the plasma of Bothrops jararaca (jararaca). Toxicon. 1991;29:673-81.

Teixeira CF, Cury Y, et al. Hyperalgesia induced by Bothrops jararaca venom in rats: role of eicosanoids and platelet activating factor (PAF). Toxicon. 1994;32(4):419-26. 
Teixeira CF, Landucci EC, Antunes E, Chacur M, Cury Y. Inflammatory effects of snake venom myotoxic phospholipases A2. Toxicon. 2003;42(8):947-62.

Teixeira C, Fernandes FCM, et al. Inflammatory effects of snake venom metalloproteinases. Mem Inst Oswaldo Cruz. 2005;100 Suppl 1:181-4.

Thwin MM, Gopalakrishnakone P. Snake envenomation and protective natural endogenous proteins: a mini review of the recent developments (1991-1997). Toxicon. 1998;36(11):1471-82.

Tracey KJ. The inflammatory reflex. Nat Insight Rev. 2002;420(19/26):852-59.

Trebien HA, Calixto JB. Pharmacological evaluation of rat paw oedema induced by Bothrops jararaca venom. Agents Actions. 1989;26(3-4):292-300.

Valente RH, Dragulev B, Perales J, Fox JW, Domont GB. BJ46a, a snake venom metalloproteinase inhibitor. Isolation, characterization, cloning and insights into its mechanism of action. Eur J Biochem. 2001;268:3042-52.

Wallace JL. Distribution and expression of cyclooxygenases (COX) isoenzymes, their physiological roles, and the categorization of nonsteroidal anti-inflammatory drugs. Am $\mathrm{J}$ Med. 1999;107(6A):11-6.

Warrell DA. The global problem of snakebite: its prevention and treatment. In: Gopalakrishnakone P, Tan CK, editors. Recent advances in toxinology research. Singapore: National University of Singapore; 1992. vol. 1, p. 121-53.

Werz O. Inhibition of 5-lipoxygenase product synthesis by natural compounds of plant origin. Planta Med. 2007;73:1331-57.

Woltmann G, McNulty CA, et al. Interleukin-13 induces PSGL-1/P-selectin-dependent adhesion of eosinophils, but not neutrophils, to human umbilical vein endothelial cells under flow. Blood. 2000;95(10):3146-52.

Zamuner SR, Gutiérrez JM, Muscará MN, Teixeira SA, Teixeira CF. Bothrops asper and Bothrops jararaca snake venoms trigger microbicidal functions of peritoneal leukocytes in vivo. Toxicon. 2001;39:1505-13. 
Zamuner SR, Teixeira CF. Cell adhesion molecules involved in the leukocyte recruitment induced by venom of the snake Bothrops jararaca. Med Inflamm. 2002;11(6):351-7

Zhang WW, Thorlacius, H. Dexamethasone inhibits arteriolar leucocyte rolling and adhesion induced by tumor necrosis factor $-\alpha$ in vivo. Inflamm Res. 2000;49:95-7.

Zingali RB, Jandrot-Perrus M, Guillin MC, Bon C. Bothrojaracin, a new thrombin inhibitor isolated from Bothrops jararaca venom: Characterization and mechanism of thrombin inhibition. Biochemistry. 1993;32:10794-10802. 